\title{
Floods in Central Texas, August 1-4, 1978
}

U.S. GEOLOGICALSURVEY PROFESSIONALAA PER 1332

Report prepared jointly by the U.S. Geological Survey and the National Oceanic and Atmospheric Administration

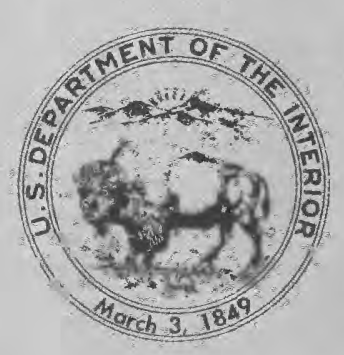




\section{Floods in Central Texas, August 1-4, 1978}

$B y$ E. E. SCHROEDER and B. C. MASSEY, U.S. Geological Survey, and EDWIN H. CHIN, National Weather Service, National Oceanic and Atmospheric Administration

U. S. G E O L O G I C A L S U R V E Y P R O F E S S I O N A L P A P E R 1332

Report prepared jointly by the U.S. Geological Survey and the National Oceanic and Atmospheric Administration 


\title{
DEPARTMENT OF THE INTERIOR
}

\section{DONALD PAUL HODEL, Secretary}

\section{U.S. GEOLOGICAL SURVEY}

\author{
Dallas L. Peck, Director
}

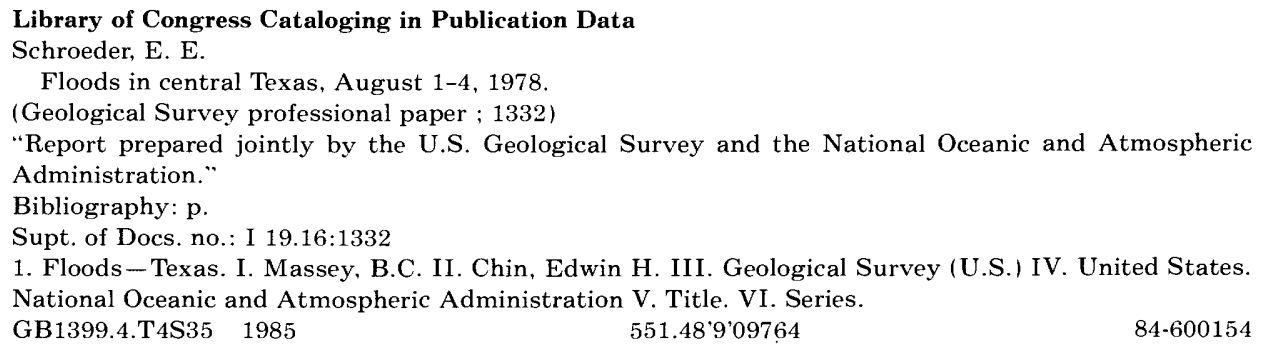

$84-600154$

For sale by the

Books and Open-File Reports Section

U.S. Geological Survey

Federal Center

Box 25425

Denver, CO 80225 


\section{CONTENTS}

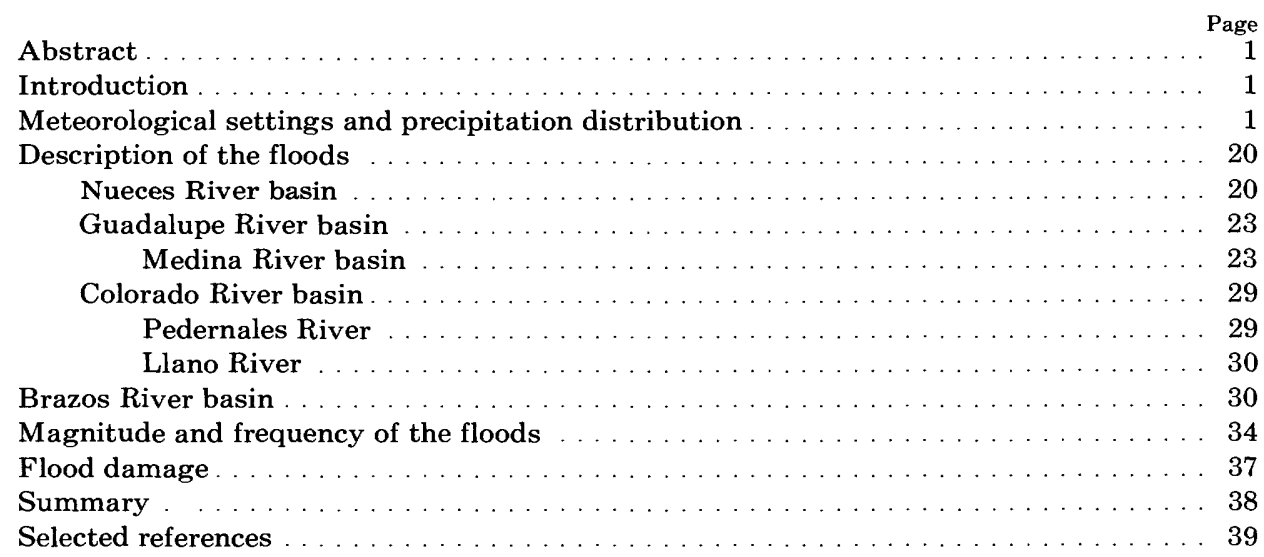

\section{ILLUSTRATIONS}

FIGURE 1. Map showing location of streamflow-data sites

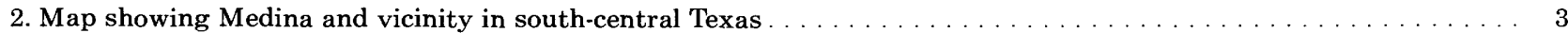

3. Map showing track of Amelia

4. Maps showing surface weather at 0600 c.s.t., July 30-August 4, 1978

5. Maps showing $500-\mathrm{mb}$ analysis at 0600 c.s.t., July 30 -August 4,1978

6. Graph showing evolution of $1000-\mathrm{mb}$ dewpoint temperature at Corpus Christi, San Antonio, and Abilene from July 31 to August 4, 1978.

Maps showing 850-mb temperature an

9. Map showing 700-mb, 12-hour net vertical displacement and K Index valid at 1800 c.s.t., July 31,1978 . . . . . . . . 15

10. Map showing isohyetal analysis for south-central Texas, August $2-3,1978 \ldots \ldots \ldots$

11. GOES infrared imagery, August 2 and $3,1978 \ldots \ldots \ldots \ldots$

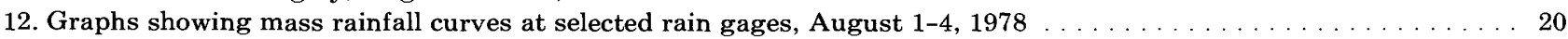

13. Maps showing isohyetal analyses for storms centered near Medina and Albany . . . . . . . . . . . . . . . . 24

14. Graphs showing depth-area duration analysis for storms centered near Medina and Albany . . . . . . . . . . 26

15. Discharge hydrograph of Guadalupe River at Comfort for August 1-6, 1978 . . . . . . . . . . . . . . 27

16. Discharge hydrograph of Guadalupe River near Spring Branch for August 1-6, 1978 . . . . . . . . . . . . . . . 27

17. Discharge hydrographs of Medina River near Pipe Creek for August 2-7, 1978, and Beaver Creek near Mason for August 2-5, 1978

19.

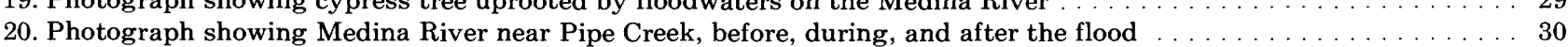

21. Discharge hydrographs of North Fork Hubbard Creek near Albany for August 3-6, 1978, and Hubbard Creek

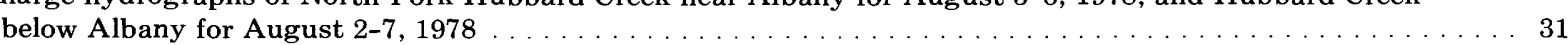

22. Discharge hydrograph of Clear Fork Bràzos River at Fort Griffin for August 3-7, 1978 . . . . . . . . . . . . . . . 32

23. Discharge hydrograph of Clear Fork Brazos River at Eliasville for August 4-12, 1978 . . . . . . . . . . . . . . . . . 32

24. Discharge hydrographs of Millers Creek near Munday for August 4-7, 1978, and California Creek near Stamford

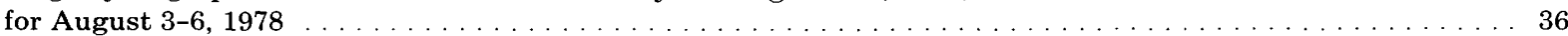

25. Photograph showing inundation of State Highway 173 and the Medina River bridge at Bandera . . . . . . . . . 36

26. Photograph showing State Highway 290 flooded by Spring Creek near Fredericksburg . . . . . . . . . . . . . . . . 37

27. Photograph showing aerial view of the Brazos River in flood at Graham . . . . . . . . . . . . . . . . . . . 


\section{TABLES}

TABLE 1. Comparison of maximum storm rainfalls with that of historical storms over central Texas in the summer season

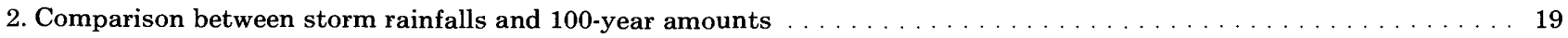

3. Comparison of extreme point rainfalls in the United States and the world $\ldots \ldots \ldots \ldots \ldots$

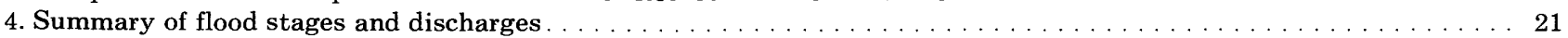

5. Locations of discontinued stream-gaging stations and miscellaneous discharge-measurement sites $\ldots \ldots \ldots \ldots$

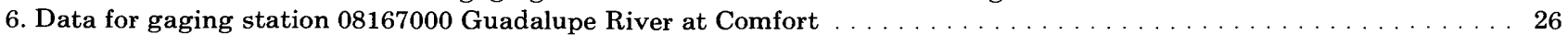

7. Data for gaging station 08167500 Guadalupe River near Spring Branch $\ldots \ldots \ldots \ldots \ldots \ldots$

8. Data for gaging station 08179000 Medina River near Pipe Creek $\ldots \ldots \ldots \ldots \ldots \ldots$

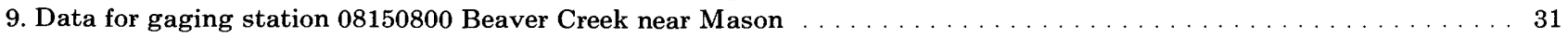

10. Data for gaging station 08086150 North Fork Hubbard Creek near Albany $\ldots \ldots \ldots \ldots \ldots$

11. Data for gaging station 08086212 Hubbard Creek below Albany $\ldots \ldots \ldots \ldots \ldots \ldots$

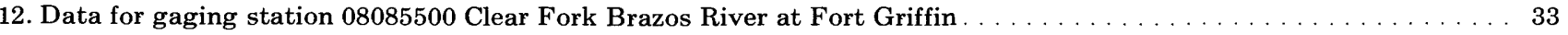

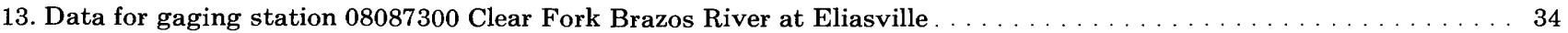

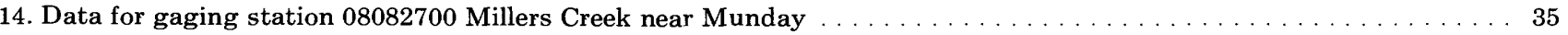

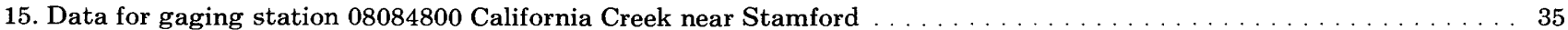

\section{GLOSSARY}

Acre-foot (acre-ft). The volume of water required to cover 1 acre to a depth of 1 foot. It equals 43,560 cubic feet, 325,851 gallons, or 1,233 cubic meters.

Contents. The volume of water in a reservoir or lake. Content is computed on the basis of a level pool or reservoir backwater profile and does not include bank storage.

Convection cloud. A cloud which owes its vertical development and possibly its origin, to convection.

Cubic foot per second $\left(\mathrm{ft}^{3} / \mathrm{s}\right)$. A rate of discharge. One cubic foot per second is equal to the discharge of a stream of rectangular cross section, 1 foot wide and 1 foot deep, flowing at an average velocity of 1 foot per second. It equals 28.32 liters per second or 0.02832 cubic meters per second.

Cubic foot per second per square mile $\left[\left(\mathrm{ft}^{3} / \mathrm{s}\right) / \mathrm{mi}^{2}\right]$. The average number of cubic feet per second flowing from each square mile of area drained by a stream, assuming that the runoff is distributed uniformly in time and area. One cubic foot per second per square mile is equivalent to 0.01093 cubic meter per second per square kilometer.

Dew point (or dew temperature). The temperature to which a given parcel of air must be cooled at constant pressure and constant water-vapor content in order for saturation to occur.

Drainage area of a stream at a specific location. The contributing area of a stream, measured in a horizontal plane, bounded by topographic divides. Drainage area is given in square miles. One square mile is equivalent to 2.590 square kilometers.

Flash flood. A local and sudden flood which usually follows brief heavy precipitation.

Flood. Any high streamflow that overtops natural or artificial banks of a stream and overflows onto land not usually underwater and causes or threatens damage.

Flood peak. The highest value of the stage or discharge attained by a flood.

Flood profile. A graph of the elevation of water surface of a river in flood, plotted as ordinate, against distance, plotted as abscissa.

Flood stage. The approximate elevation of the stream when overbank-flooding begins.

Front. The interface or transition zone between two airmasses of different density.
Gaging station. A particular site on a stream, canal, lake, or reservoir where systematic observations of gage height or discharge are obtained.

Isohyetal map. A map showing lateral distribution of precipitation and drawn as contours of equal rainfall depths.

Jet stream. High-velocity strong winds concentrated within a narrow stream high in the atmosphere.

Mean sea level. The annual mean sea level is the average of hourly heights of the tide from a calendar year of tidal record. This is referenced to the National Geodetic Vertical Datum of 1929.

Millibar (mb). A unit of pressure equal to 1,000 dynes per square centimeter.

National Geodetic Vertical Datum (NGVD). Formerly called Sea Level Datum of 1929. A geodetic datum derived from a general adjustment of the first order level nets of both the United States and Canada. In the adjustment, sea levels from selected tide stations in both countries were held as fixed. The year indicates the time of the last general adjustment. This datum should not be confused with mean sea level.

$\boldsymbol{N}$-year precipitation (rain). A precipitation amount which can be expected to occur, on the average, once every $N$ years.

Precipitable water. The total atmospheric water vapor contained a vertical column of unit cross-sectional area extending from the surface up to a specified pressure level, usually $500 \mathrm{mb}$.

Rawinsonde. A radiosonde tracked by a radio direction-finding device to determine the winds aloft.

Recurrence interval. As applied to flood events, recurrence interval is the average number of years within which a given flood peak will be exceeded once.

Ridge. An elongated area of high atmospheric pressure.

Time of day expressed in 24-hour time. For example, 12:30 a.m. is 0030 hours, 1:00 p.m. is 1300 hours.

Unit discharge. The average number of cubic feet of water flowing per second from each square mile of area drained, assuming that the runoff is distributed uniformly in time and area.

Vorticity. A vector measure of local rotation in a fluid flow, defined mathematically as the curl of the velocity vector. In meteorology, vorticity usually refers to the vertical component of the vector. 
CONTENTS

\section{CONVERSION OF INCH-POUND UNITS TO}

\section{INTERNATIONAL SYSTEM OF UNITS (SI)}

[Most units of measure used in this report are inch-pound units. The following factors may be used to convert inch-pound units to the International System of Units (SI).]

\begin{tabular}{lcl}
\hline \multicolumn{1}{c}{ Multiply } & By & \multicolumn{1}{c}{ To obtain } \\
\hline acre-foot (acre-ft) & 1,233 & cubic meter \\
cubic foot per second $\left(\mathrm{ft}^{3} / \mathrm{s}\right)$ & 0.02832 & cubic meter per second \\
cubic foot per second & 0.01093 & cubic meter per second \\
$\quad$ per square mile $\left[\left(\mathrm{ft}^{3} / \mathrm{s}\right) / \mathrm{mi}^{2}\right]$ & & per square kilometer \\
degrees Fahrenheit $\left({ }^{\circ} \mathrm{F}\right)$ & $5 / 9(\mathrm{~F}-32)$ & meter \\
foot $(\mathrm{ft})$ & .3048 & millimeter \\
inch $(\mathrm{in})$ & 25.4 & kilometer per hour \\
knot $(\mathrm{kn})$ & 1.85 & kilometer \\
mile (mi) & 1.609 & kilometer per hour \\
mile per hour $(\mathrm{mph})$ & 1.609 & kilopascal $(\mathrm{kPa})$ \\
millibar $(\mathrm{mb})$ & 0.1 & kilometer \\
nautical mile $(\mathrm{nmi})$ & 1.85 & square kilometer \\
square mile $\left(\mathrm{mi}^{2}\right)$ & 2.590 &
\end{tabular}





\title{
FLOODS IN CENTRAL TEXAS, AUGUST 1-4, 1978
}

\author{
By E.E. Schroeder and B.C. Massey, U.S. Geological Survey, \\ and EDWIN H. CHIN, NATIONAL WEATHER SERVICE, NATIONAL OCEANIC \\ and ATMOSPHERIC ADMINISTRATION
}

\begin{abstract}
Catastrophic floods caused by record rainfall occurred in central Texas during August 1-4. 1978. Torrential rain initiated by the remnants of tropical storm Amelia fell over south-central Texas during August 1-3, and very intense rain due to the interaction between the cold front and maritime air mass fell over north-central Texas on August 3-4. Rainfall of more than 48 inches near Medina in south-central Texas established a new United States record of extreme point rainfall for a 72-hour period.

Major flooding occurred on the Medina and Guadalupe Rivers. Severe to minor flooding occurred on the Brazos, Llano, Pedernales, and Nueces Rivers. Floods with recurrence intervals in excess of 100 years and recordsetting peak discharges were observed at several streamflow stations.

Thirty three lives were lost and total damages reportedly exceeded $\$ 110$ million.
\end{abstract}

\section{INTRODUCTION}

Catastrophic floods caused by intense rainfall occurred in central Texas during Aug. 1-4, 1978. The rain was initiated by remnants of tropical storm Amelia but was compounded by other meteorological factors. Torrential rain fell over the hill country area of south-central Texas during Aug. $1-3$, and over the big country area of north-central Texas during Aug. 3-4. A maximum rainfall of more than $48 \mathrm{in}$. at a location $11 \mathrm{mi}$ northwest of Medina $\left(29^{\circ} 49^{\prime} \mathrm{N}\right.$. $99^{\circ} 15^{\prime} \mathrm{W}$.) set a new extreme point rainfall record for a 72 -hour period in the United States. A map of central Texas is shown in figure 1, and a map of Medina and vicinity (expanded scale) is shown in figure 2 .

Major flooding occurred on the Medina River and its tributaries above Medina Lake and on the Guadalupe River and its tributaries above Canyon Lake. Moderate to severe flooding occurred on tributaries of the Nueces River, on Clear Fork Brazos River and its tributaries, and on the Llano and Pedernales Rivers, which are tributaries of the Colorado River. Peak discharges at several streamflow stations exceeded the historic peaks. The highest unit discharge observed was $3,010 \mathrm{ft} 3 / \mathrm{s} / \mathrm{mi}^{2}$ from the $14.1-\mathrm{mi}^{2}$ drainage area of Spring Creek, which is a tributary of the Pedernales River.

Much of the extraordinary runoff was in the form of flash flooding. About half of the town of Medina was damaged, and many buildings in the city of Bandera farther downstream on the Medina River also were damaged. Medina Lake had $4 \mathrm{ft}$ of flow over the spillway at maximum stage. In northcentral Texas, $6 \mathrm{ft}$ of water inundated the town of Albany on a tributary of Clear Fork Brazos River, forcing people to seek safety on roofs and trees. Floodwater opened gaps in the earthen dam of Albany Reservoir and overtopped the spillway at Lake Throckmorton. A total of 33 people lost their lives due to the floods. Property damages were estimated at $\$ 110$ million.

This report presents the meteorlogical situations and the precipitation distributions that caused the floods and a description of the floods by basins with peak stages and discharges and flood-frequency estimates. Detailed dischargehydrograph data, including historic maxima are presented in tabular form for 10 gaging stations. These should be of considerable value in assessing the risks involved in developing the flood plains of streams in the affected area.

This report was prepared jointly by the U.S. Geological Survey and the National Oceanic and Atmospheric Administration and in cooperation with the State of Texas and other agencies.

\section{METEOROLOGICAL SETTINGS AND PRECIPITATION DISTRIBUTION}

The disturbance that developed into tropical storm Amelia originated off the African coast as a tropical wave on July 19, 1978. It remained a weak system without much deep convection until it reached the central Caribbean Sea on July 26. On July 29, as the wave moved off the Yucatan Peninsula into the southwestern Gulf of Mexico, convection increased and the cloud mass took on a circular appearance on satelite pictures. By Sunday morning, July 30 , the disturbance had turned toward the northwest and the cloud band structure had appeared. The track of Amelia is shown in figure 3, and surface analysis for the period July 30-August 4 is shown in figures $4 \mathrm{~A}-\mathrm{F}$. All time mentioned in this report refers to central standard time (c.s.t.) unless stated otherwise. The surface analysis at $0600 \mathrm{July} 30$ (fig. 4A) indicated very flat 


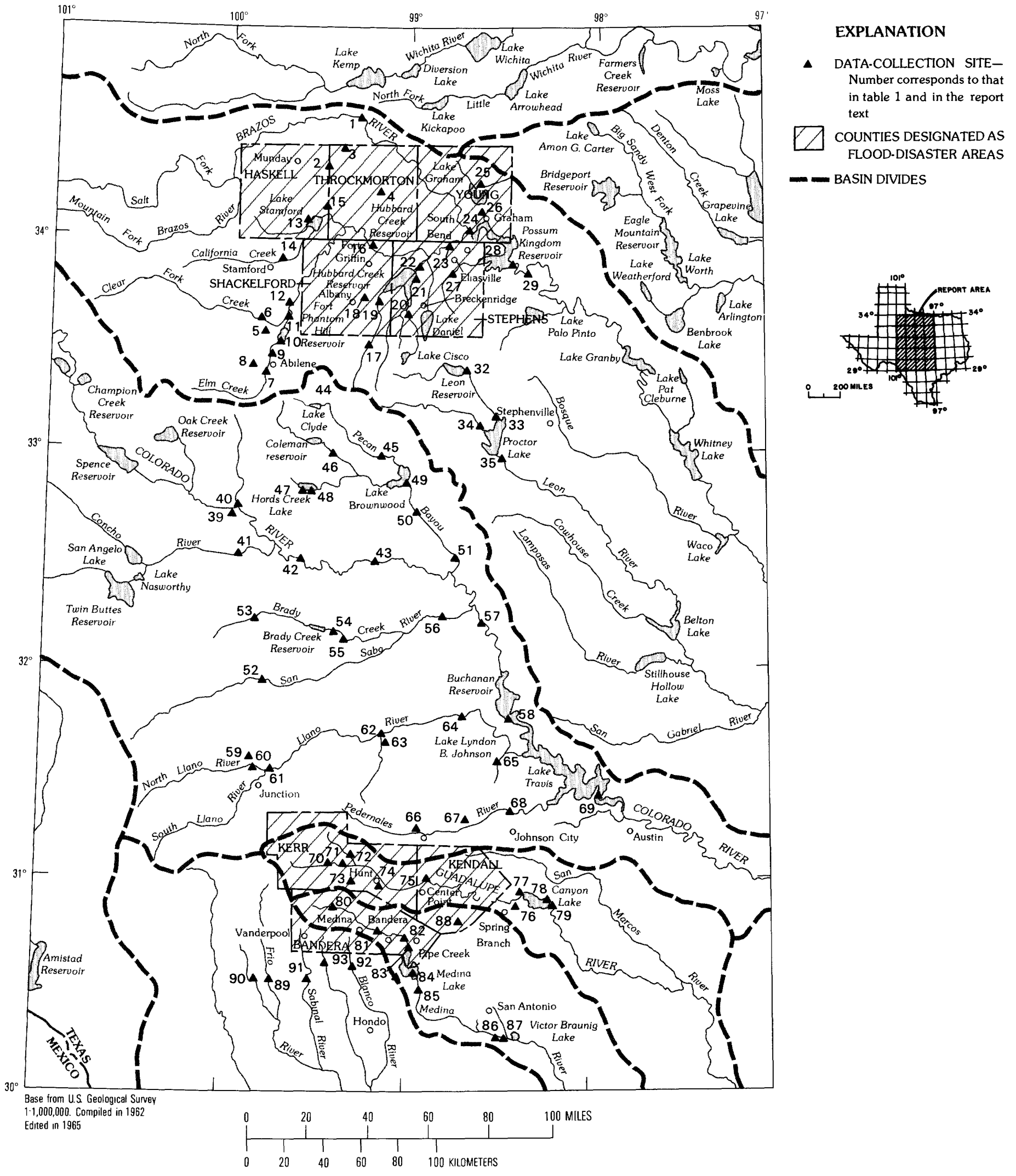

FIGURE 1.-Location of streamflow-data sites. 


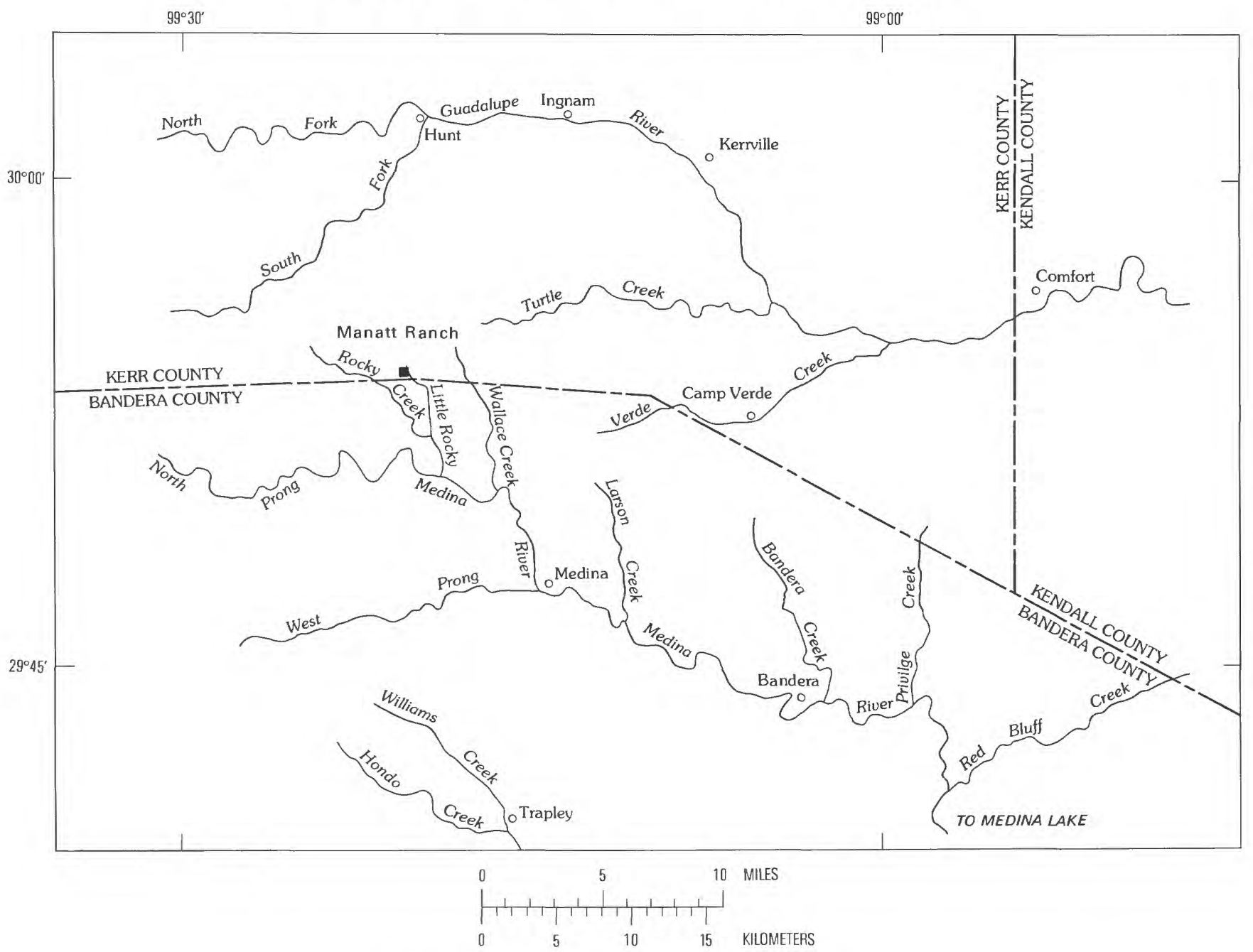

FIGURE 2.-Medina and vicinity in south-central Texas.

pressure gradient over Texas, with the coastal stations of Corpus Christi and Brownsville having light easterly winds with overcast sky. The low pressure center, which was to develop into Amelia, was centered in the western Gulf of Mexico at $23.5^{\circ} \mathrm{N} .95^{\circ} \mathrm{W}$. The corresponding $500-\mathrm{mb}$ analysis (fig. 5A) showed a flat contour gradient with very light southeasterly winds of about $10 \mathrm{kn}$ (knots) over the eastern two-thirds of Texas. A very weak low center was situated over north-central Mexico.

During the day of July 30 , the low pressure center that was to develop into Amelia continued on a north-northwestward track at $10 \mathrm{mph}$. Before crossing the Texas coast north of Brownsville during the evening of July 30 , this system reached tropical storm intensity, with winds in excess of 45 $\mathrm{kn}$. The estimate of storm intensity was based on data obtained by reconnaissance flights through the storm. By 2200 July 30, Amelia was $40 \mathrm{mi}$ north of Brownsville. During the night, Amelia continued on a northwesterly track and by 0600 Monday, July 31, was about $50 \mathrm{mi}$ west by north of
Corpus Christi at approximately $28.0^{\circ} \mathrm{N} .97 .8^{\circ} \mathrm{W}$. The pressure gradient along the southwest Texas coast from near Brownsville to just east of Corpus Christi tightened during this period indicating a stronger onshore flow of warm moist air from the Gulf of Mexico. During July 31, the storm continued to drift northwestward while its circulation continued to weaken. The surface center of circulation could be traced inland to the west of San Antonio during the night of July 31-August 1 , after which it was no longer identifiable. After the low was filled, the surface analysis at 0600 Tuesday, August 1 (fig. 4C) indicated continued onshore southeasterly flow and strong moisture advection. For example, with the wind southerly or southeasterly at Corpus Christi and vicinity on July 31 and August 1, warm maritime air with a mixing ratio of 22.5 grams of water vapor per kilogram of dry air near the surface was moving into south-central Texas. This predominantly southeasterly circulation pattern persisted throughout the life of the storm systems as can be seen from surface maps at 0600 August 2-4 (figs. 4D-F). 

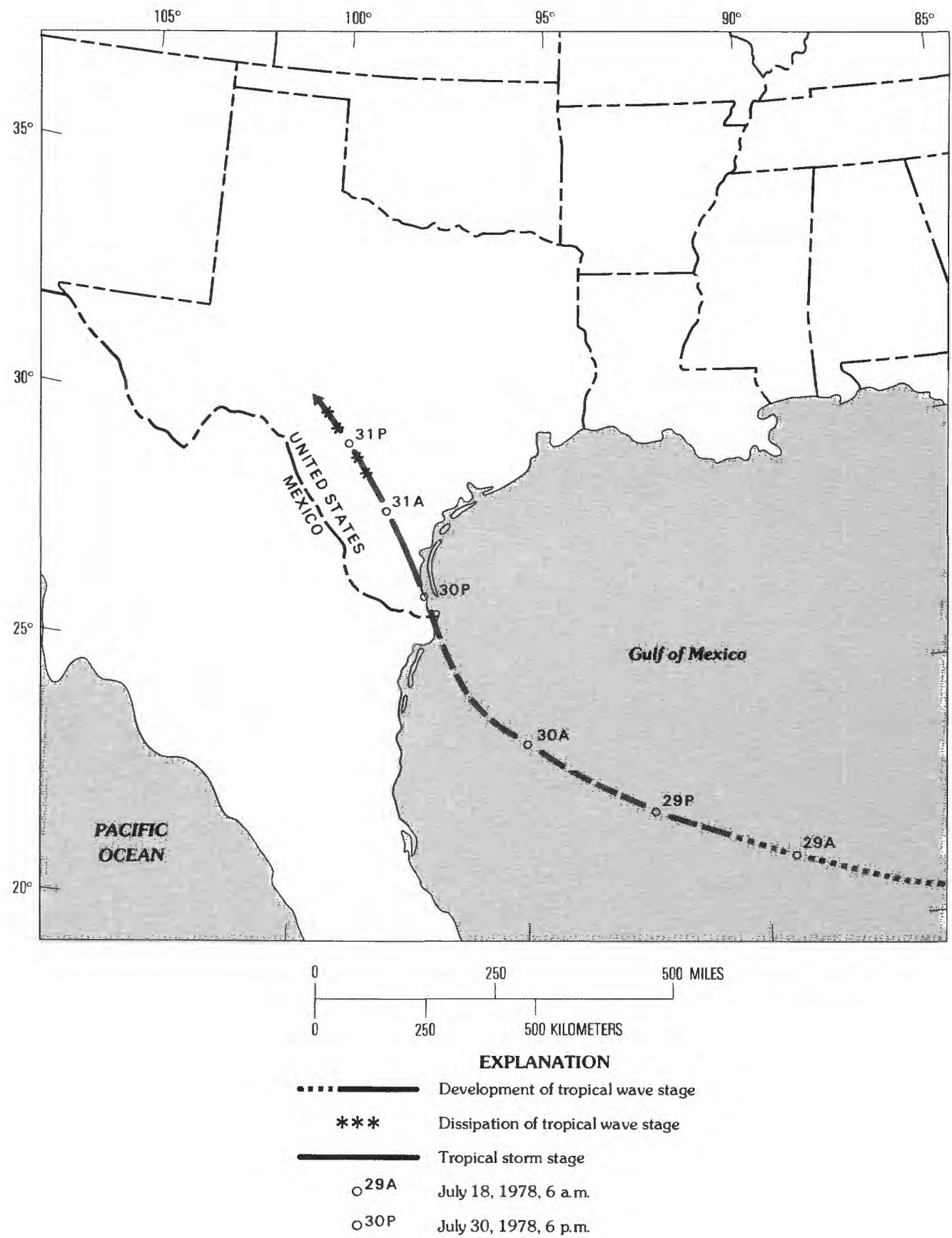

Figure 3.- Track of Amelia.

Figure 4(facing page).—Surface weather at 0600 c.s.t. $A$, July 30, 1978; $B$, July 31, 1978. 

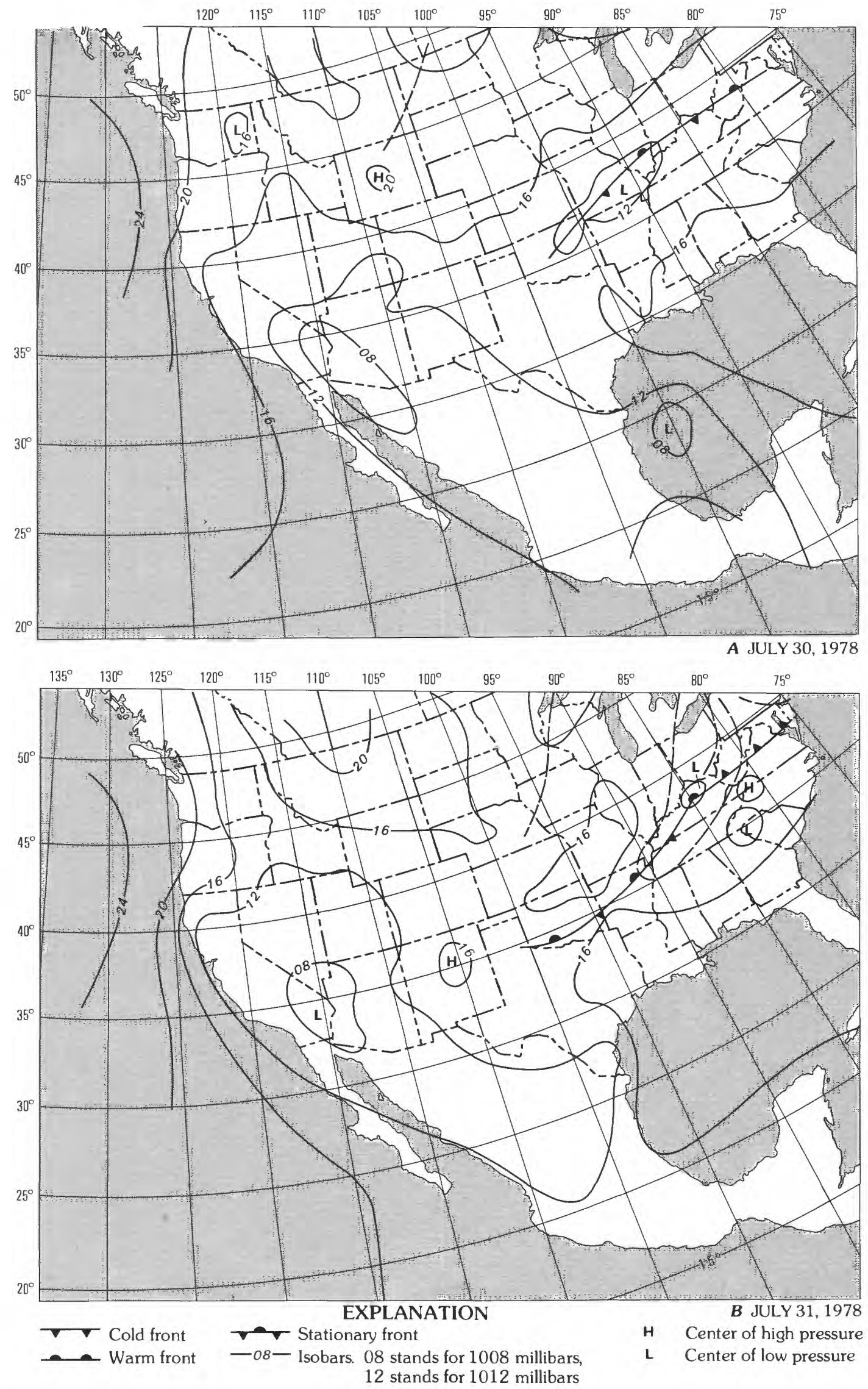

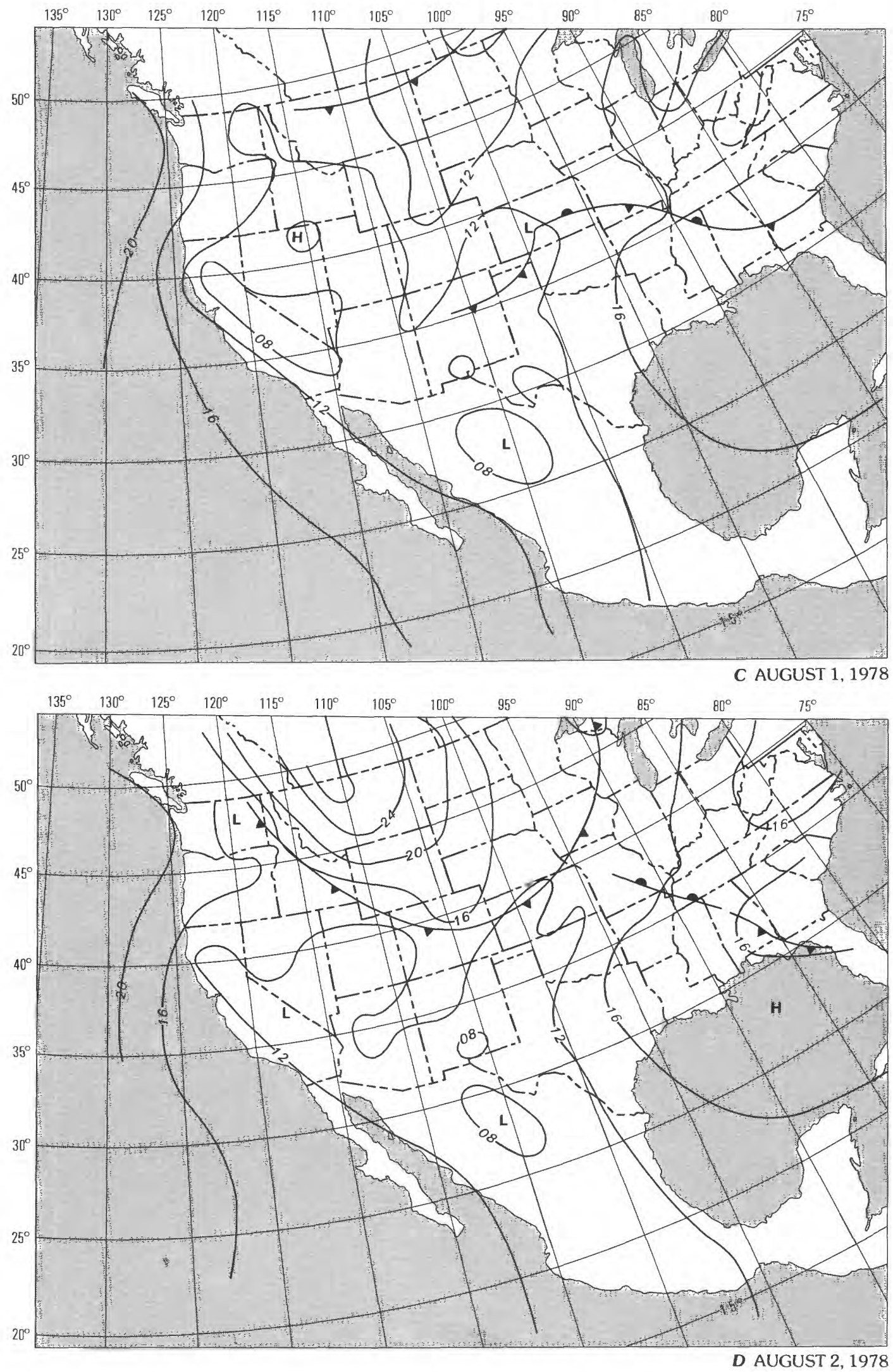

Figure 4.-Surface weather at 0600 c.s.t. $C$, August 1, 1978; $D$, August 2, 1978. 

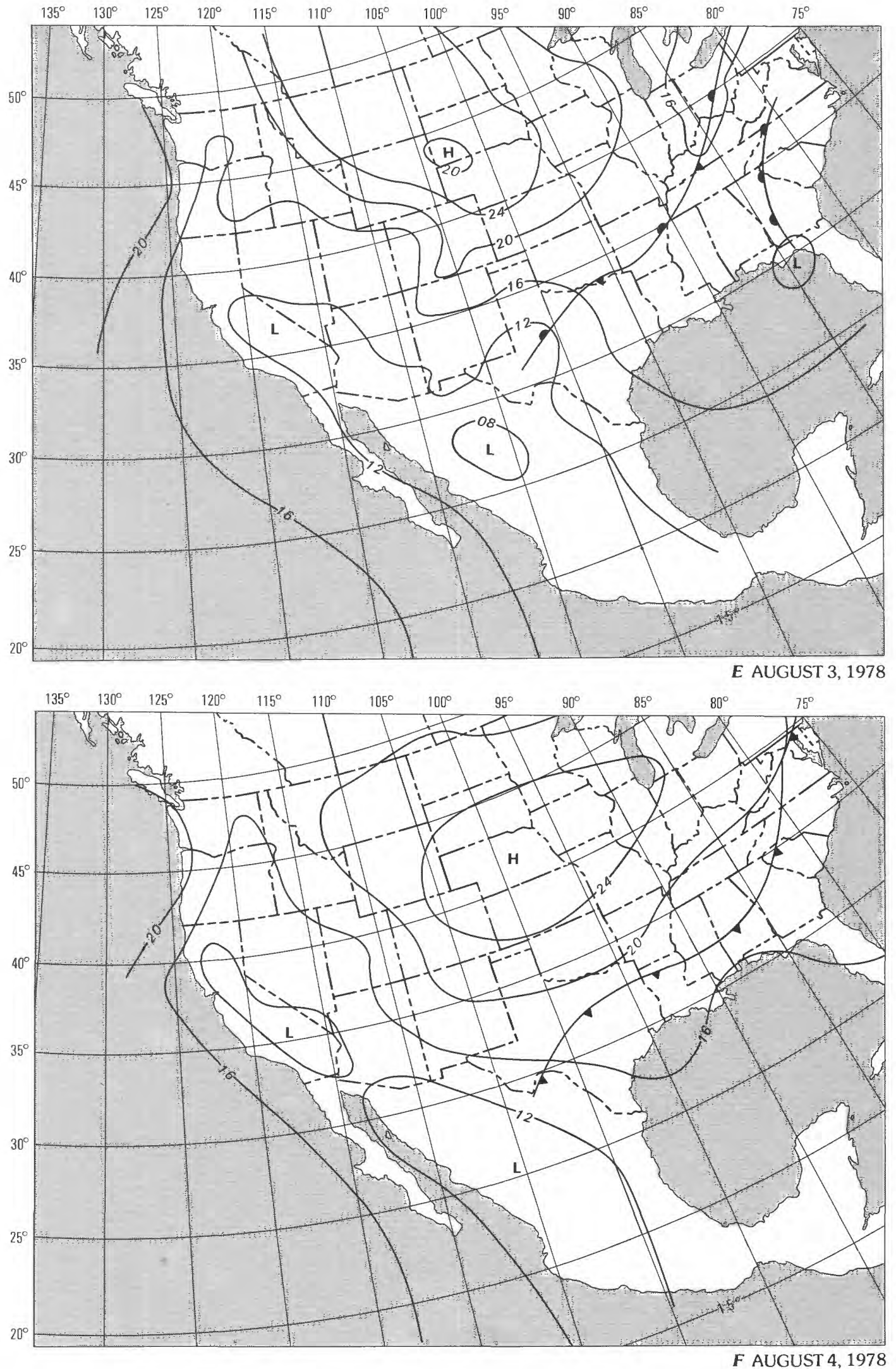

Figure 4.-Surface weather at 0600 c.s.t. $E$, August 3, 1978; $F$, August 4, 1978. 
The evolution of the $500-\mathrm{mb}$ circulation pattern from July 30-August 4 is shown in figures $5 \mathrm{~A}-\mathrm{F}$. It was characterized by flat contour gradient and very light southerly wind during the entire storm period. Il was not until the morning of August 4 that the winds picked up over central Texas. At 0600 August 1 a vorticity center (fig. 5C, marked with $\mathrm{X}$ ) with the central value greater than $8 \times 10^{-5} \mathrm{~s}^{-1}$ was located over northern Mexico just south of Del Rio, Texas. This vorticity center later migrated northward through the hill country and was over north-central Texas by the morning of August 3 (not shown). This vorticity center, combined with the remnants of Amelia and strong northward flow of moisture, all played a role in the extreme precipitation.

The evolution of dewpoint temperatures at Corpus Christi, San Antonio, and Abilene from July 31 to August 4, adjusted to $1,000-\mathrm{mb}$ level for easy comparison, is shown in figure 6 . A common measure of moisture used in many hydrometeorological studies is the persisting 12 -hour 1.000 -mb dewpoint. The surface dewpoints at observing stations are reduced to $1,000 \mathrm{mb}$ adjusting the observed values at the moist adiabatic lapse rate. The persisting 12-hour 1,000-mb dew point then is the value that has been equaled or exceeded for a time interval of 12 consecutive hours. Studies have been conducted to determine smoothed regional and monthly values of this measurement of moisture (Environmental Science Services Administration, 1968). These values for Texas in late July and early August vary from just over $78^{\circ} \mathrm{F}$ (degrees Fahrenheit) near the coast to $58^{\circ} \mathrm{F}$ at Abilene. At Corpus Christi from the early afternoon of July 31 to midday of August 4, the dewpoint temperature was within a few degrees of this climatological extreme. In fact, the previous record was just slightly exceeded during the night of July 31-August 1 when the dewpoint temperature stayed at $79^{\circ} \mathrm{F}$. At San Antonio and Abilene, the departures from the climatological extremes were slightly greater than at Corpus Christi. At San Antonio it was about $6^{\circ} \mathrm{F}$ below. Early in the period the dewpoint at Abilene was considerably below the extremes. It continued to increase as the moist air moved northward, and by the evening of August 3, was within about $9^{\circ} \mathrm{F}$ of the climatological extremes.

General comparison can also be made between dewpoint temperatures in figure 6 and the August mean dewpoint temperatures, also adjusted to $1,000 \mathrm{mb}$, which was $74^{\circ} \mathrm{F}$ at Corpus Christi, $70^{\circ} \mathrm{F}$ at San Antonio, and $67^{\circ} \mathrm{F}$ at Abilene (Environmental Science Services Administration, 1968). The observed dewpoints were considerably higher than the climatic values at Corpus Christi from the evening of July 31 through the morning of August 4 and also at Abilene from the afternoon of August 2 through the morning of August 4. This high moisture content was not limited to the surface level. The evolution of precipitable water from the surface to $500 \mathrm{mb}$ in Texas and vicinity is shown in figure 7 . High precipitable water content of $1.50 \mathrm{in}$. or more already covered coastal and southern Texas by the morning of July 31. By the morning of August 1, the southeastern two-thirds of Texas had precipitable water in excess of $1.50 \mathrm{in.} \mathrm{By} 0600$ August 2, the area with precipitable water greater than 1.50 in. covered central Texas, while there was a reduction of precipitable water in other regions.

The rawinsonde station closest to the precipitation center in the north-central Texas region of the big country is located at Stephenville, approximately $75 \mathrm{mi}$ east-southeast of Albany. The sounding at 0600 August 2 (at Stephenville) had total precipitable water of $1.72 \mathrm{in}$. from the surface to $500 \mathrm{mb}$. Precipitable water climatic statistics for Stephenville were not available for comparison. The nearest station with statistics available is at Fort Worth, $60 \mathrm{mi}$ northeast of Stephenville. At Fort Worth. the mean monthly precipitable water for August was $1.41 \mathrm{in}$. with standard deviation of $0.30 \mathrm{in}$.

Temperature and trajectories at $850 \mathrm{mb}$ for 0600 August 1 and August 2 are shown in figures $8 \mathrm{~A}-\mathrm{B}$. For example, an air parcel arriving at $850 \mathrm{mb}$ near Fort Worth during the morning of August 1 originated over the Gulf of Mexico about $40 \mathrm{mi}$ east of Corpus Christi $24 \mathrm{~h}$ earlier. By inference, an air parcel arriving at $850 \mathrm{mb}$ over the vicinity of Medina would have originated over a Gulf region further south. Both figures show that warm advection was prevalent and Gulf air was continuously being brought into central Texas.

The rawinsonde station near Victoria, Texas, is located upstream and to the southeast of the precipitation center of the hill country storm. Total precipitable water from the surface to $500 \mathrm{mb}$ at Victoria was $1.97 \mathrm{in}$. at 0600 on both July 31 and August 1. For comparison, the corresponding mean August precipitable water at Victoria was $1.46 \mathrm{in}$. with standard deviation of 0.27 in. (Lott, 1976). The observed mean of semimonthly maxima of precipitable waters at 0600 for the last half of July was 1.83 in. with standard deviation of 0.18 in. and for the first half of August was $1.82 \mathrm{in}$. with standard deviation of 0.17 in. (Ho and Riedel, 1979). These climatic statistics, however, should be viewed with some caution because they were derived from a data sample of 7 years of data at Victoria (July 1966-December 1972) combined with 21 years of data at San Antonio (January 1946-June 1966). The maximum observed value for the period of record for the last half of July was 2.10 in. observed on July 22, 1972, and for August it was 2.26 in. observed on August 4, 1966. The observed precipitable water thus exceeds the average maximum values and were within 15 percent of the highest observed. Surface wind was southeasterly at $10 \mathrm{kn}$ and the $500-\mathrm{mb}$ wind over Victoria was southeasterly at 20 $\mathrm{kn}$ at 0600 both days. There is no doubt that very moist maritime air brought in by the prevailing southeasterly flow through midtroposphere was in place prior to the outbreak of the storm over the hill country during the night of July 31-August 1.

Figure 5(facing page). -500 -mb analysis at 0600 c.s.t. $A$, July 30 , 1978; B, July 31, 1978. 

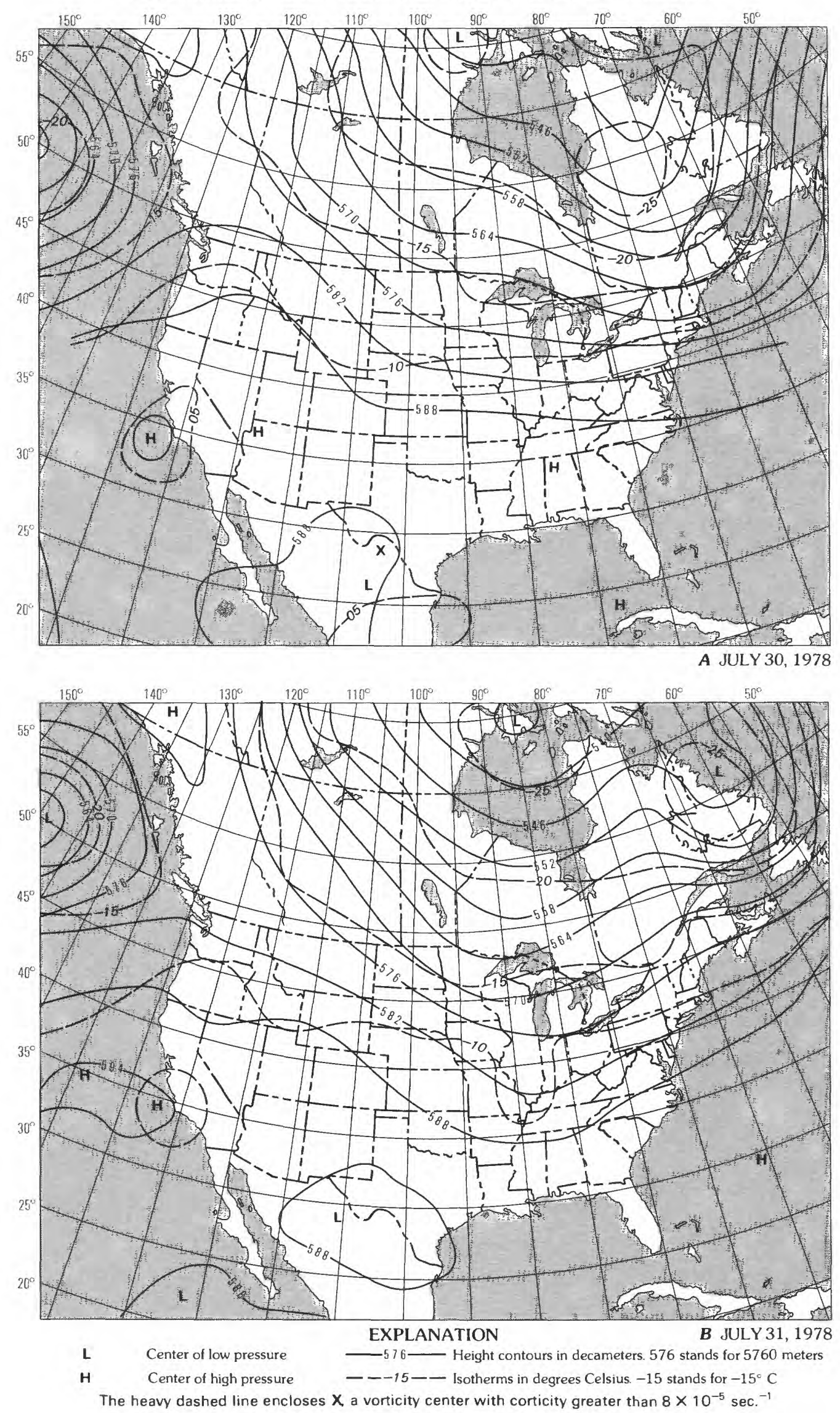

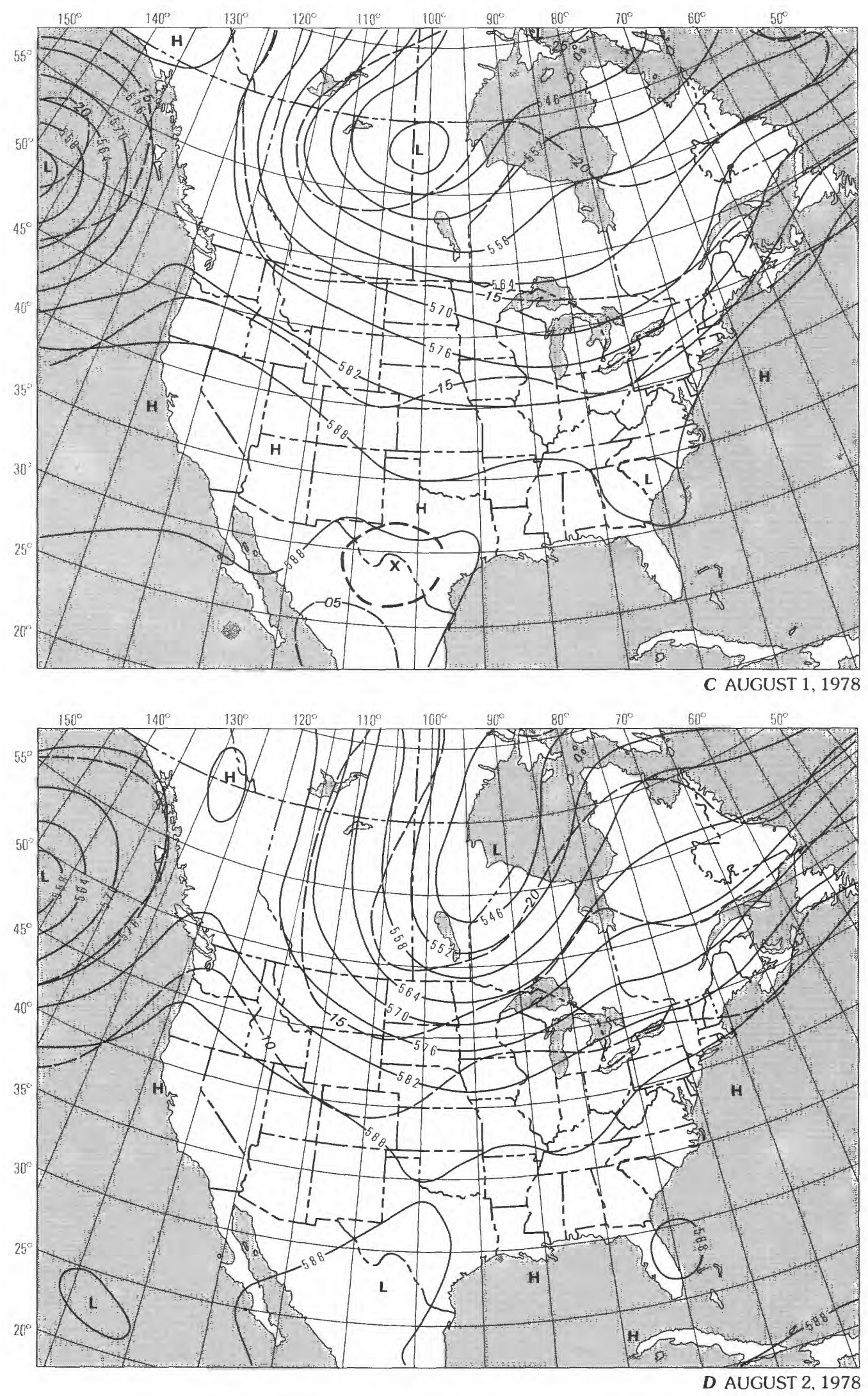

Figure 5.-500-mb analysis at 0600 c.s.t. $C$, August 1, 1978; D, August 2, 1978. 

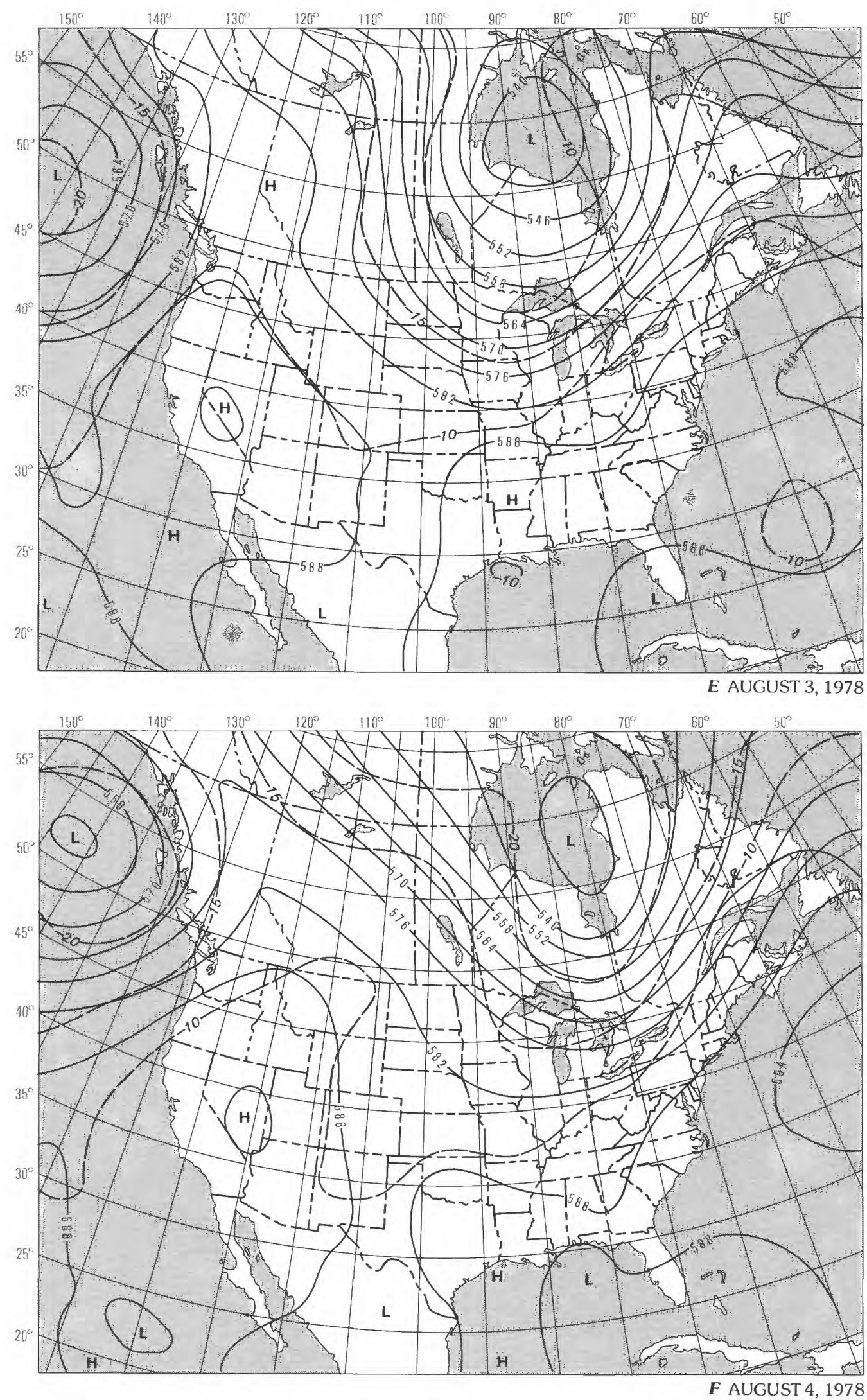

Figure 5.-500-mb analysis at 0600 c.s.t. $E$, August 3, 1978; $F$, August 4, 1978. 


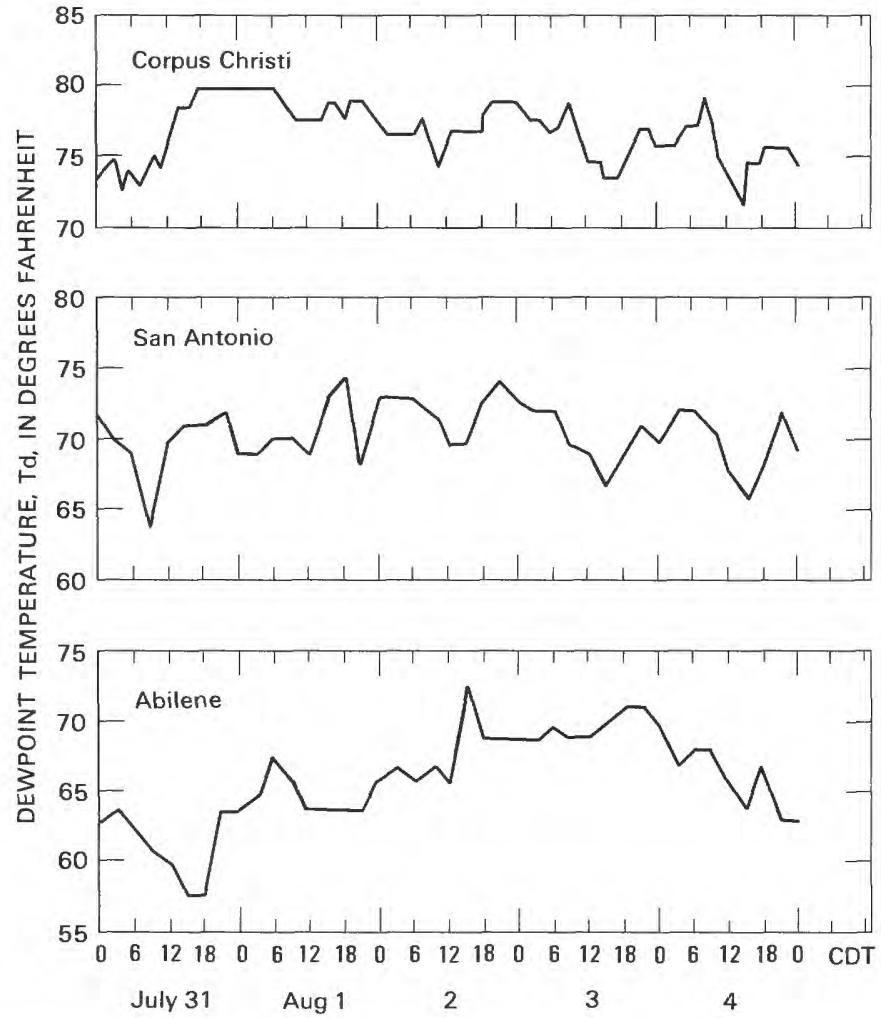

FIGURE 6. - Evolution of 1000-mb dewpoint temperature at Corpus Christi, San Antonio, and Abilene from July 31 to August 4. 1978.

Synoptic scale rising (sinking) motion provides an environment favorable (unfavorable) to the development of mesoscale convective systems. Floods resulting from convective storms that produce heavy rainfall are most unlikely to occur in an environment of strong synoptic scale subsidence and sinking motion. This is an example of the control exerted by the synoptic scale on smaller scale events. The 12-hour net vertical displacement for air parcels reaching $700 \mathrm{mb}$ at 0600 and 1800 was positive (upward) over central Texas during July 31-August 5. The only brief interlude was 12 hours ending at 0600 August 2, when the net vertical displacement was downward over north-central Texas. This was at a time before there was significant weather over north-central Texas. This subsidence field in effect prevented moist low-level air from rising, thus building up the potential for intense convective activity later on. The net vertical displacement (north-central Texas) reverted to positive again after the morning of August 2 and prior to the storm outbreak in Albany and vicinity. This rising motion persisted and intensified during the evening of August 3 and throughout the morning of August 4.

The stability prognosis indicated a $\mathrm{K}$ Index greater than 32 over the hill country during the morning of July 31 , increasing to more than 40 in the evening. The $\mathrm{K}$ Index is a measure of the air-mass moisture content and static stability, and is given by:

$$
K=\left(T_{850}-T_{500}\right)+T_{d}, 850-\left(T_{700}-T_{d}, 700\right)
$$

where $T$ and $T_{d}$ are temperature and dew point, respectively, in degrees Celsius; and the subscripts denote pressure level, in millibars. The larger the $\mathrm{K}$ Index of the air mass, the more unstable the air mass is. In general, a $\mathrm{K}$ Index greater than 35 is associated with numerous thunderstorms; an index smaller than 20 with no thunderstorms.

The 12-hour net vertical displacement of an air parcel arriving at $700-\mathrm{mb}$ level over southeastern Texas in the evening of July 31 was $20 \mathrm{mb}$. This corresponded to a synoptic scale rising motion of $0.5+\mathrm{cm} / \mathrm{sec}$ (centimeter per second). By itself, this was a moderate rising motion, but it was a relative maximum. Figure 9 shows these two parameters at 1800 July 31 , just prior to the first rain event over the hill country. By Tuesday morning, the vorticity center formerly over Mexico had crossed the Texas border. The moisture envelope also reached as far north as the Balcones Escarpment, which runs from the Del Rio area to San Antonio and northeastward to Austin. This is an uplift zone where surface elevation rises some $800 \mathrm{ft}$ in about $10 \mathrm{mi}$ and marks the beginning of the rough terrain that froms the Edwards Plateau.

With the meteorological factors so favorable, convective storms developed and rain began to fall during the night of July 31-August 1 over the eastern part of the hill country through the San Antonio area. The rain continued during the morning, spreading northwestward. Total rainfall amounted to 4-5 in. which primed the area where much heavier rain would fall later. The Manatt Ranch, about 11 mi northwest of Medina on the upper tributary of Little Rocky Creek, which is tributary to the Medina River, had 5 in. during this first burst. The city of Kerrville, $18 \mathrm{mi}$ north-by-east from Medina, received $6 \mathrm{in}$. during this initial rain.

Convective activity over the hill country diminished sharply during the afternoon of Tuesday, August 1. By Tuesday evening, however, convection intensified over southern Texas and slowly spread northward toward the hill country. By 2200 , the first light rainfall moved into the Medina and Guadalupe River watersheds. Satellite pictures revealed that the large area of convection in south-central Texas had diminished partially in late evening. But by midnight Tuesday, new cells had developed within the decaying area, about 40-50 mi west of San Antonio. These new cells grew rapidly in size and intensity and moved very slowly through Bandera, Kerr, Gillespie, and Kendall Counties, producing torrential rain in the early morning hours of Wednesday, August 2. The rains diminished later in the morning, but Manatt Ranch received over $31 \mathrm{in}$. of rain during this second major rainfall burst. The city of Medina received more than 24 in. Headwater regions of the Guadalupe River centered around Kerrville received over $11 \mathrm{in}$. 


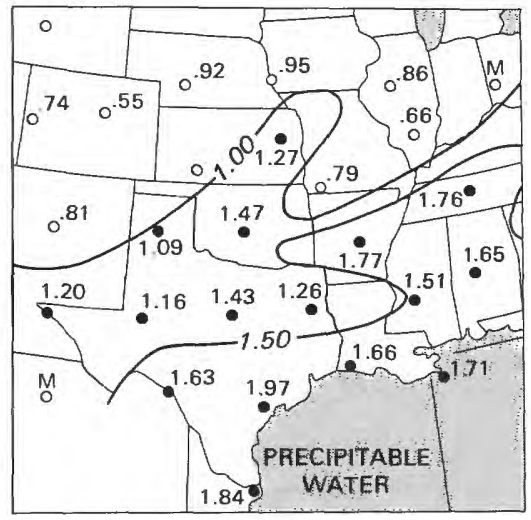

July 31

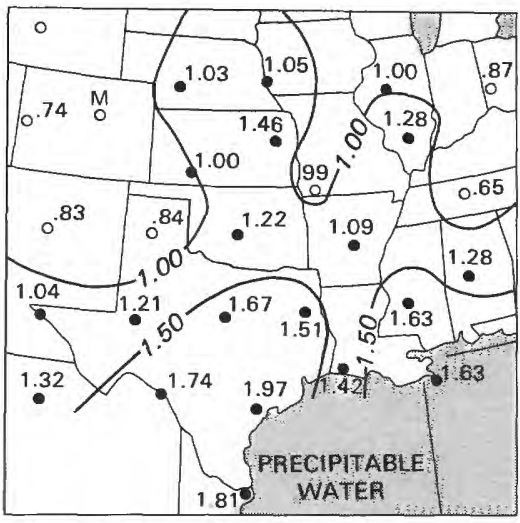

August 1

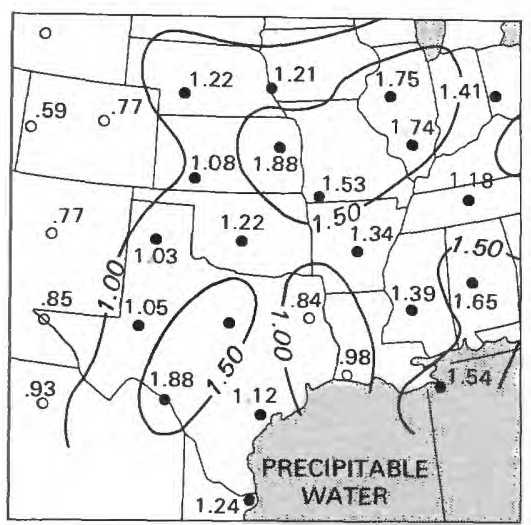

August 2

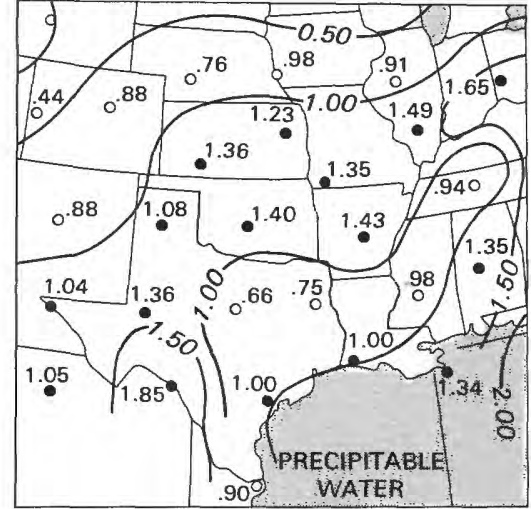

August 3

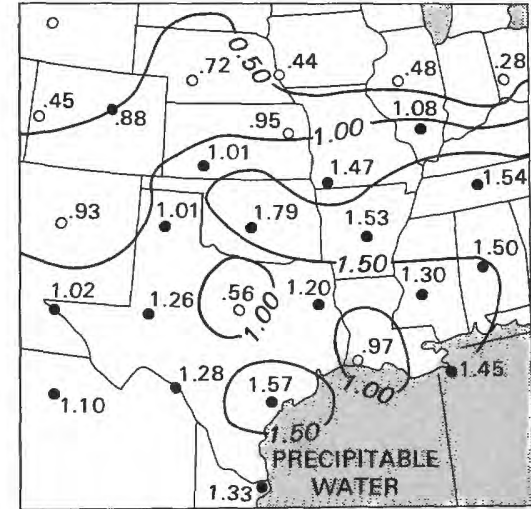

August 4

FiguRE 7. - Evolution of precipitable water trom surface to 500 -mb at 0600 c.s.t.. July 31 to August $4,1978$.

Rain continued during much of Wednesday at a slightly reduced rate and over a more northern region - north and northwest of the upper Guadalupe and Medina basins, but by about 1900 , scattered convective showers started further south in northwestern Bandera County. Around 2230, satellite IR (infrared) imagery showed that the cells started to intensify and expand rapidly, spreading northeastward over central Kerr County, western Gillespie and southeastern Mason Counties. The precipitation center, with rainfall exceeding 20 in., was located in west-central Gillespie County. Rainfall was heaviest from just prior to midnight to the early morning of Thursday, August 3. Manatt Ranch was again in the path of the storm and had an additional $12 \mathrm{in}$. of rain during this third and last major rain burst over the hill country. Therefore, in 3 days ending August 3, the Manatt Ranch had a total rainfall of more than 48 in. This set a new United States record for extreme point rainfall in 72 hours although most of the rain at the Manatt Ranch fell within 52 hours. Hunt $10 \mathrm{~W}$ recorded $7.5 \mathrm{in}$. during this burst, while nearby Ingram received nearly $16 \mathrm{in.}$ Medina, which recorded $24 \mathrm{in}$. of rain the previous night, had only 0.6 in. during the night of
August 2-3, revealing the northward progression of the storms. The areal rainfall distribution of the second major burst during August 2 and the third major burst during August 3 over the hill country is shown in figure 10.

The National Weather Service operates an S-band WSR-57 weather radar at Hondo, about $45 \mathrm{mi}$ south-southeast from the maximum precipitation area centered in a grid square $30 \mathrm{nmi}$ on a side $\left(900 \mathrm{nmi}^{2}\right.$ ) enclosing the Manatt Ranch. The accumulated rainfall from 1830 August 1 to 0730 August 2, conservatively estimated from radar Video Integrator Processor (VIP) levels for this grid square, was about 11 in. The same conservative estimate from 1850 August 2 to 0530 August 3 was about 20 in. (Moore and Smith, 1979). This suggested that areal average rainfall was much heavier on the second night than on the first night. A more detailed analysis as represented by figure 10 , indicated that the center (periphery) of the maximum storm rainfall was indeed over the ranch on the first (second) night, with a major portion of area of heaviest rain outside (inside) of the grid square on the first (second) night. This may partly explain the apparent difference between the time of maximum point 

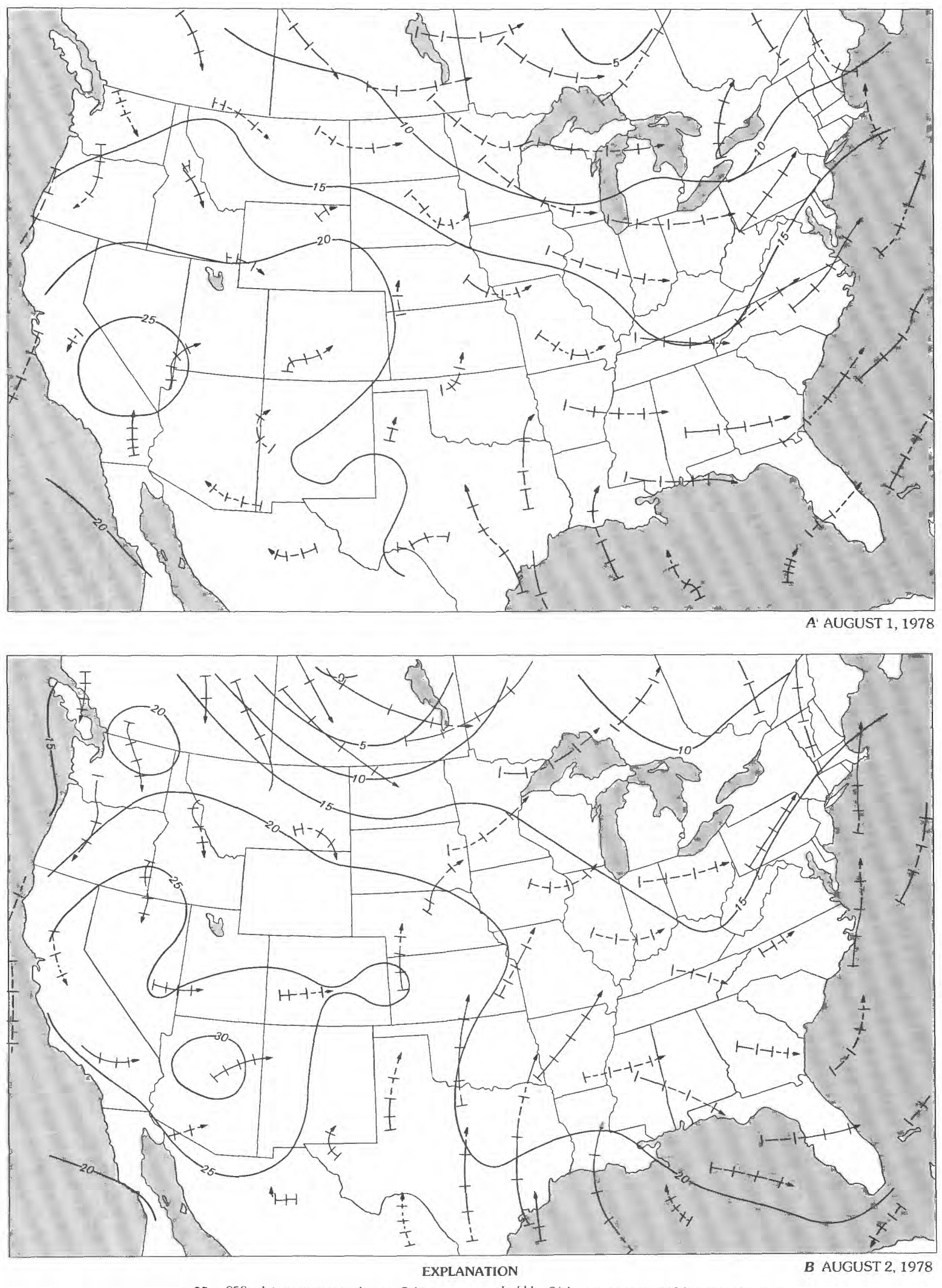

Figure 8. -850-mb temperature and 24-h trajectory valid at 0600 c.s.t. $A$, August 1, 1978; B, August 2, 1978. 


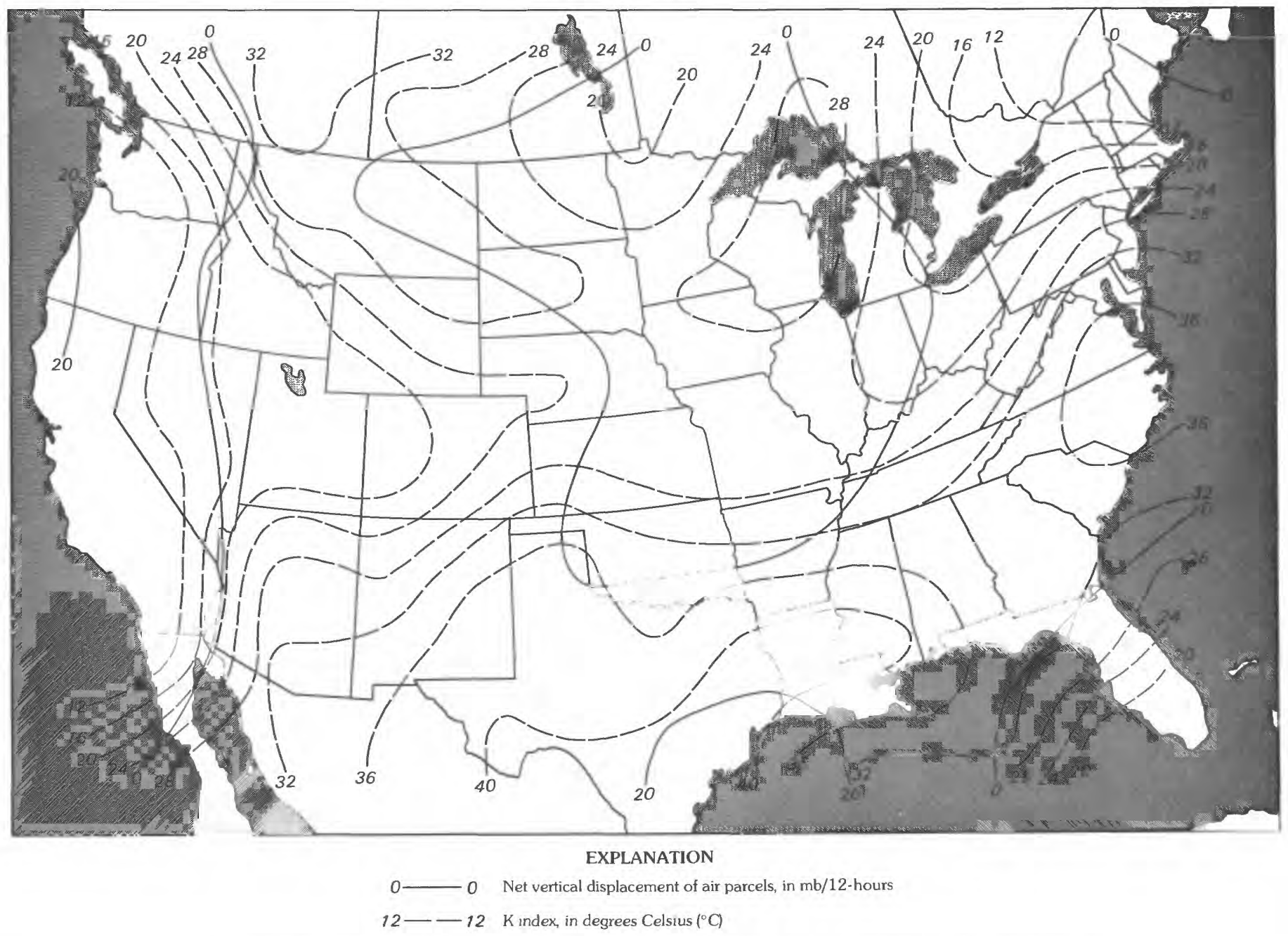

Figure 9. - 700-mb, 12-hour net vertical displacement and K Index valid at 1800 c.s.t., July $31,1978$.

rainfall at Manatt Ranch (31 in. the night of August 1-2) and the time of maximum areal rainfall estimated by radar (the night of August 2-3).

The prevailing south or southeasterly flow over the Gulf Coast and central Texas persisted through August 4. By the morning of August 1, the warm maritime air mass was advancing into north-central Texas. A further increase in dewpoint occurred at Abilene during August 2-3 (fig. 6), indicating strong local moisture convergence. An area of strong vorticity $\left(8 \times 10^{-5} \mathrm{~s}^{1}\right)$ was now situated over northcentral Texas. The surface analysis showed that a cold front, which earlier had extended from Idaho and Colorado, through Kansas eastwards, had now passed the panhandle area. Ahead of this front, a trough formed briefly and the pressure dropped noticeably along the trough. By 2111 August 3 , the cold front had reached north-central Texas and briefly became stationary, but started to move southward again as a cold front by the early morning of August 4.
Strong convection due to the interaction between this front-trough system and the maritime air mass coming from the south produced heavy rain in Haskell, Throckmorton, and Shackelford Counties in the big country (north-central Texas) beginning during the early morning of August 3. Rain was most intense during the evening and night of August 3-4. Major portions of these three counties received amounts greater than $10 \mathrm{in}$. in 2 days. Some areas of Shackelford County had more than $25 \mathrm{in}$., with a maximum of $32.5 \mathrm{in} .3$ mi west of Albany.

Albany is a ranch town of 2,000 people situated on the north bank of a tributary to the Brazos River. Shackelford County, like most of the big country that surrounds Abilene, is considerably flatter and drier than the hill country. It is mostly an area of wide open space devoted to large-scale farming and ranching. The terrain is not particularly hilly, elevations range from 1,300 to $1,900 \mathrm{ft}$ above NGVD. Moist tropical air masses occasionally penetrate this deep into 


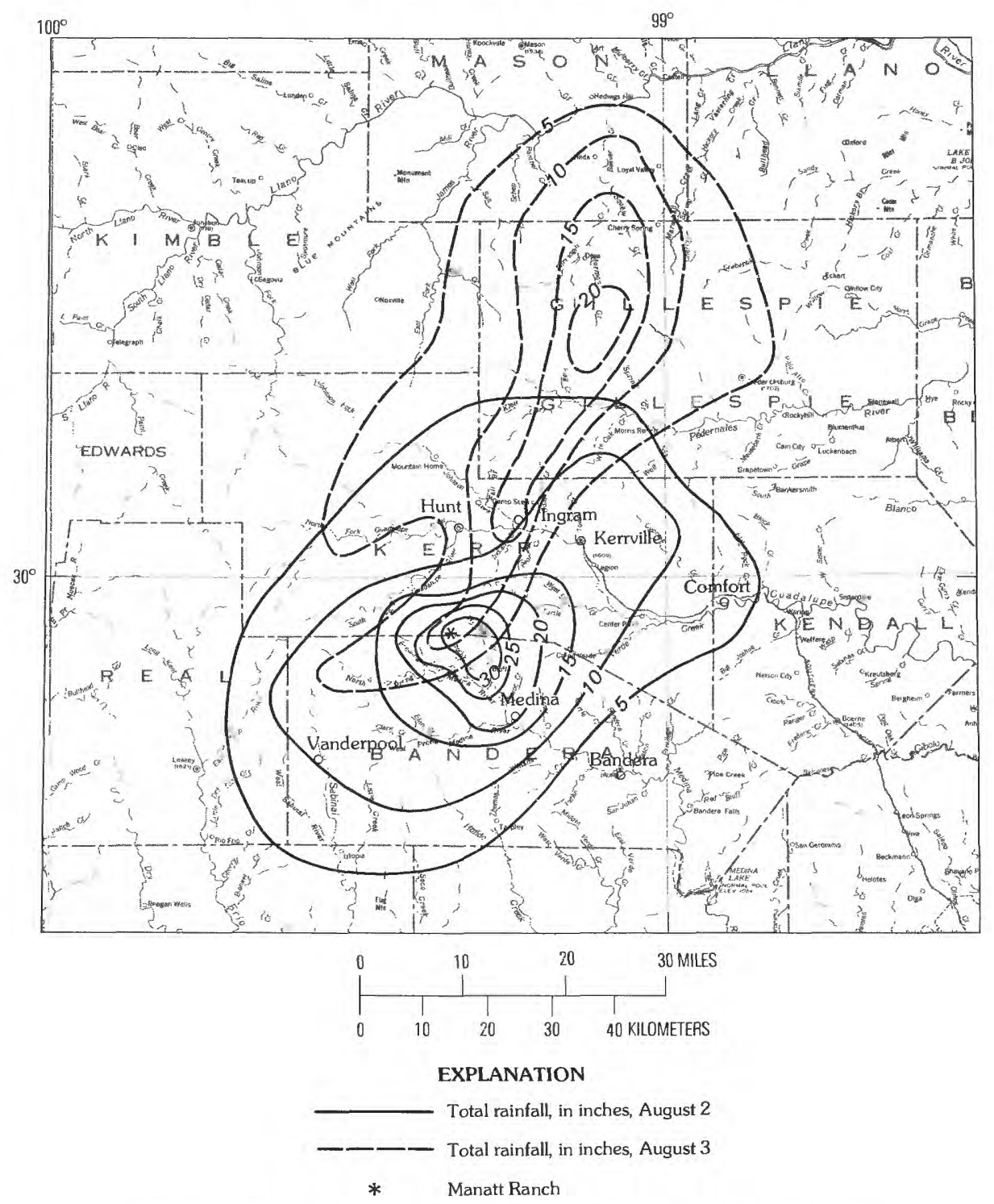

FIGURE 10.- Isohyetal analysis for south-central Texas, August 2-3, 1978.

Texas, but excessive rainfall and flash flooding are somewhat less common and usually less severe than in the hill country or coastal region.

The NOAA Geostationary Operational Environmental Satellite (GOES) is constantly looking at the earth's cloud pattern from $22,500 \mathrm{mi}$ in space in an earth synchronous orbit. The GOES image was very valuable during this meteorological event to reveal that high-level outflow persisted even after the surface low had vanished. However, quantitative precipitation estimates using the Schofield-Oliver technique (Schofield and Oliver, 1977) were found to be considerably lower than the observed amount. The original technique was designed for short-lived isolated thunderstorms with large updrafts and rapidly expanding anvils. Long-lived, slow-moving large-area thunderstorm systems such as those that occurred over the Texas hill country during August 2-3 or over the Texas big country during August 3-4, are associated with strong, steady-state updrafts and outflows. The subsidence outside the rainshaft causes the anvil to erode at its outer edge as fast as new cloud material arrives at the tops of the storm. Heavy rain could fall continuously without any visible sign of anvil expansion. Also a slowmoving thunderstorm cluster could remain in the same area for 3 or more hours, as did the thunderstorm systems that yielded torrential rain over the hill country during August 1-3 and over the big country during August 3-4.

As a result, large areas become greatly saturated and there is no longer any dry air entrainment into the sides of individual updrafts in the center of the cluster. Entrainment of dry air not only reduces the moisture content of the 

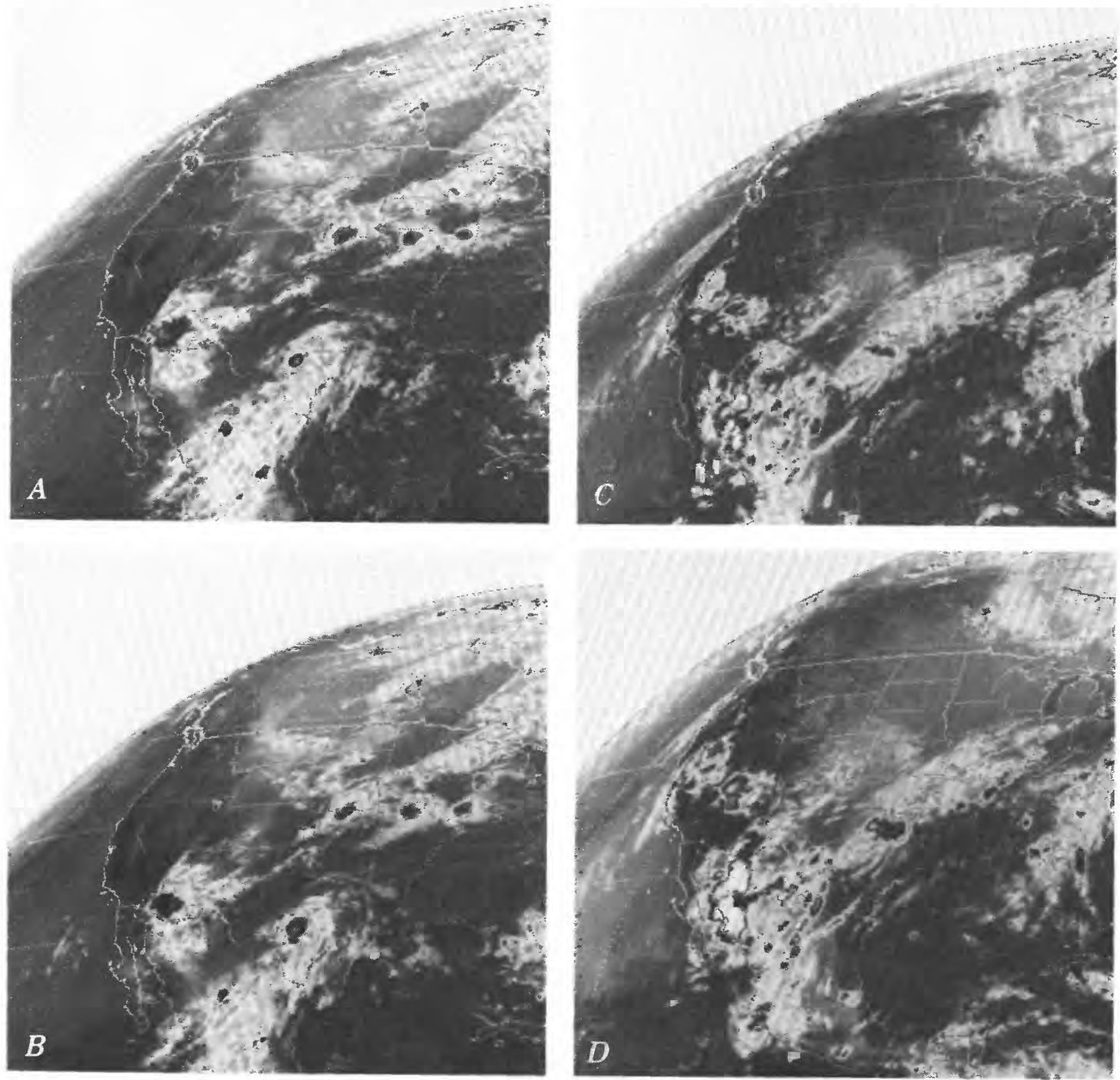

Figure 11.-GOES infrared imagery. A, 0100 c.s.t., August 2, 1978; B, 0200 c.s.t., August 2, 1978; $C$, 1930 c.s.t., August 3, 1978; D, 2030 c.s.t., August 3, 1978.

rising column but also tends to produce a lapse rate of temperature for the saturated parcel greater than the saturated adiabatic lapse rate to reduce the buoyancy forces and inhibit further cumulus growth. Without this inhibitive factor, convective cells in the central part of a storm system would be able to produce much more rain than isolated thunderstorms.
Schofield and Oliver (1980) proposed an improved rainfall estimation procedure based mainly on the experience of applying rainfall estimation technique to the storms over central Texas under discussion. Using satellite IR imagery and taking into account the saturated environment factor, they estimated a rainfall of $11.05 \mathrm{in}$. at $4.5 \mathrm{mi}$ northwest of 
Medina during the $6 \frac{1 / 2}{2}$ hours ending 0400 August 2. However, this still represented an underestimate of about 4.5 in. The reason for the difference is that by its nature, GOES IR rainfall estimation is approximately an $80-\mathrm{km}^{2}$ (square kilometer) areal average, while surfacé observation can be a point maximum.

Klazura (1971) measured drop-size distributions in warm cumuli over southeast Texas. He confirmed the expectation that the higher the cloud builds, the broader the dropletsize spectrum and the larger the concentration of large drops; this in turn leads to a highly efficient collisioncoalescence process for rain formation. The enhanced GOES IR images at 0100 and 0200 August 2 and again at 1930 and 2030 August 3 are shown in figures 11A-D. These were time periods when each storm had rapid development. The growth of the cumulonimubus towers was evident. At 2030 August 3 the storm over north-central Texas had a cloudtop temperature of $-80^{\circ} \mathrm{C}$ (degrees Celsius), which translated to a cloudtop height exceeding $55,000 \mathrm{ft}$. Comparable heights were reached by cloud towers associated with the hill country storm. The radar summary issued by the National Weather Service indicated that an echo top of $40,000 \mathrm{ft}$ was observed over the hill country at 0530 August 4 . The existence of high cloud tops and high echo tops suggested high precipitation efficiencies. The difference in cloud heights between those reported by radar summary and those sensed by satellite radiometer in this instance is, of course, due mainly to the difference in time of observation. However, even if observation time is the same for the same cloud, radar summary usually reports a lower height than that reported by satellite observation. This is because radar detects large precipitation-size particles such as rain drops or graupels but cannot detect much smaller, supercooled cloud droplets and small ice crystals near the cloud top where temperatures are sensed by satellite IR radiometer.

The disastrous Texas floods of August 1-4, could be recognized as the result of two separate major storms of different origin and distinguishable time and geographical context but with some shared features. The presence of very moist maritime air that originated in the Gulf of Mexico and the presence of positive vorticity advection preceded the outbreak of both storms. In the case of the storm of August 1-3 over the hill country, moist Gulf air mass initially was brought into south-central Texas by the cyclonic circulation of the remnant of tropical storm Amelia. Considerable rain fell over the Texas Coastal Plains and over part of the hill country during the night of July 31 -August 1 . The very unstable atmospheric structure with high $\mathrm{K}$ Index remained over south-central Texas as well as the continuation of warm air advection after filling of Amelia. There was an established pattern throughout the duration of the storm that convective activity would subside during the day but would reinvigorate as evening approached. During the nights of both August 1-2 and August 2-3, thunderstorms developed over the southern part of the hill country. Satellite IR pictures showed that as the cells grew, merged, and then slowly moved northward against the Balcones Escarpment, orographic lifting enhanced the release of convective instability thus increasing rainfall intensity. Major contributions to rainfall for the hill country storm were observed on these two nights.

The storm of August 3-4 over the big country resulted from the interaction of a cold front with the maritime air mass that penetrated deeply into north-central Texas. This deep penetration of maritime air was the result of the persistent southeasterly flow field through a deep layer for at least 2 days prior to the storm outbreak over Albany and vicinity during the early morning hours of August 3. Orography was not a factor for the August 3-4 storm; rainfall covered a larger area than that of the hill country storm. The major contribution of the storm rainfall was in a single major rainburst during the night of August 3-4.

Selected mass rainfall curves at locations near each precipitation center are shown in figure 12. Rainfall curves for Hunt $10 \mathrm{~W}$ and Stamford 2 were derived from recording gages, other curves were constructed from bucket survey data with limited time resolution. It is clear, however, that the rainfall rates were intense. For example at the northern center, a total amount of $32.5 \mathrm{in}$. fell at Albany $3 \mathrm{~W}$, but $23 \mathrm{in}$. of the total fell during an 8-hour period ending at 0200 August 4. Isohyetal analyses of the storm centered near Medina is shown in figure 13A and for the storm centered near Albany in figure $13 \mathrm{~B}$.

Preliminary depth-area-duration analysis of the hill country storm with a maximum centered near Medina is shown in figure $14 \mathrm{~A}$ and for the big country storm with a maximum centered near Albany is shown in figure 14B. A comparison with the areal rainfall of historic storms with those that occurred during the summer of 1978 over central Texas (Shipe and Riedel, 1976) is given in table 1.

It is evident from the depth-area-duration analyses that the storms of August 1978 were indeed extraordinary. Rainfall in the Medina storm established summer season records over $100-\mathrm{mi}^{2}$ areas for durations of 6,12 , and 48 hours and over $200-\mathrm{mi}^{2}$ areas for durations of 6 and 12 hours. The Albany storm was characterized by a record-setting 24-hour rainfall over $100-\mathrm{mi}^{2}$ and $200-\mathrm{mi}^{2}$ areas. It should be noted, however, that the period of comparison in table 1 covers June to August only; the September 8-10, 1921, storm centered in Thrall, Texas, for example, was not included. Comparisons between the extreme point rainfalls in these recent storms and corresponding 100-year return period amounts (Hershfield, 1961; Miller, 1964) are shown in table 2. The rare intensity of the storms is apparent.

Comparisons between the maximum at Manatt Ranch with the most extreme point rains known in the United States for 6- to 72-hour durations are shown in table 3 . The last line lists the world record rains for 1, 2, and 3 days observed at Cilaos, La Reunion, an island east of Madagascar 
TABLE 1.-Comparison of maximum storm rainfalls with that of historical storms over central Texas in the summer season.

\begin{tabular}{|c|c|c|c|c|}
\hline \multirow{2}{*}{$\begin{array}{l}\text { Area } \\
\left(m i^{2}\right)\end{array}$} & \multirow{2}{*}{$\begin{array}{l}\text { Duration } \\
\text { (hours) }\end{array}$} & \multirow{2}{*}{$\begin{array}{c}\text { Greatest on record } \\
\text { (central Texas) }\end{array}$} & \multicolumn{2}{|c|}{ Depth (in.) } \\
\hline & & & $\begin{array}{c}\text { Medina center } \\
\text { (Aug. } 1-3,1978 \text { ) }\end{array}$ & $\begin{array}{c}\text { Albany center } \\
\text { (Aug. 2-4, 1978) }\end{array}$ \\
\hline 100 & $\begin{array}{r}6 \\
12 \\
24 \\
48\end{array}$ & $\begin{array}{l}12.7 \text { (June } 27-J u l y ~ 4,1936 \text { ) } \\
16.5 \text { (June } 28-30,1940 \text { ) } \\
25.8 \text { (June } 30-J u l y 2,1932 \text { ) } \\
30.0 \text { (June 27-July 1, 1899) }\end{array}$ & $\begin{array}{l}15.4^{*} \\
20.0^{\star} \\
24.0^{*} \\
31.6^{\star}\end{array}$ & $\begin{array}{l}8.7 \\
16.0 \\
27.3^{\star} \\
30.0\end{array}$ \\
\hline 100 & $\begin{array}{r}6 \\
12 \\
24 \\
48\end{array}$ & $\begin{array}{l}12.2 \text { (June } 27-J u l y ~ 4,1936) \\
15.6 \text { (June } 28-30,1940 \text { ) } \\
23.8 \text { (June } 30-J u l y ~ 2,1934 \text { ) } \\
29.5 \text { (June } 27-\text { July } 1,1899 \text { ) }\end{array}$ & $\begin{array}{l}13.8^{\star} \\
17.7^{\star} \\
21.5 \\
28.5\end{array}$ & $\begin{array}{l}8.2 \\
15.0 \\
25.5^{\star} \\
28.1\end{array}$ \\
\hline 1,000 & $\begin{array}{r}6 \\
12 \\
24 \\
48\end{array}$ & $\begin{array}{l}10.9 \text { (June } 27-J u 1 y ~ 4,1936 \text { ) } \\
12.3 \text { (June } 27-J u l y ~ 4,1936 \text { ) } \\
21.1 \text { (June } 27-J u l y ~ 1,1699) \\
27.1 \text { (June 27-July 1, 1899) }\end{array}$ & $\begin{array}{r}9.1 \\
12.0 \\
15.0 \\
20.3\end{array}$ & $\begin{array}{r}6.4 \\
11.5 \\
19.6 \\
21.7\end{array}$ \\
\hline
\end{tabular}

* Denotes record-setting event in the summer season.

TABLE 2.-Comparison between storm rainfalls and 100-yr amounts

\begin{tabular}{|c|c|c|c|c|}
\hline Location & $\begin{array}{l}\text { 100-year } \\
\text { 24-hour rain } \\
\text { (in.) }\end{array}$ & $\begin{array}{c}\text { Storm } \\
\text { 24-hour rain } \\
\text { (in.) }\end{array}$ & $\begin{array}{l}\text { 100-year } \\
\text { 3-day rain } \\
\text { (in.) }\end{array}$ & $\begin{array}{c}\text { Storm } \\
\text { 3-day ra in } \\
\text { (in.) }\end{array}$ \\
\hline Medina IINW & 9.05 & $\begin{array}{l}\text { 30* } \\
\text { (ending } 0600 \\
\text { Aug. 2, 1978) }\end{array}$ & 11.4 & $\begin{array}{c}>48 \\
(52 \text { hours } \\
\text { Aug. } 1-3,1978)\end{array}$ \\
\hline Location & $\begin{array}{c}\text { 100-year } \\
\text { 24-hour rain } \\
\text { (in.) }\end{array}$ & $\begin{array}{l}\text { Storm } \\
\text { 24-hour rain } \\
\text { (in.) }\end{array}$ & $\begin{array}{c}\text { 100-year } \\
\text { 2-day rain } \\
\text { (in.) }\end{array}$ & $\begin{array}{c}\text { Storm } \\
\text { 2-day rain } \\
\text { (in.) }\end{array}$ \\
\hline Albany $3 \mathrm{~W}$ & 8.8 & $\begin{array}{c}29.05 \\
\text { (Aug. 4, 1978) }\end{array}$ & 10.0 & $\begin{array}{c}30.25 \\
(48 \text { hours } \\
\text { Aug. } 3-4,1978)\end{array}$ \\
\hline
\end{tabular}

* Approximate.

TABLE 3.-Comparison of extreme point rainfalls in the United States and the world.

\begin{tabular}{|c|c|c|c|c|c|c|}
\hline \multirow[b]{2}{*}{ Storm } & \multicolumn{6}{|c|}{ Duration (hours) } \\
\hline & 6 & 12 & $\begin{array}{l}18 \\
\mathrm{~A}\end{array}$ & $n^{24}$ (in & 48 & 72 \\
\hline Smethport, Pa. (July 17-18, 1942) & +30.8 & 34.3 & & & & \\
\hline Thrall, Tex. (Sept. 8-10, 1921) & & & 36.4 & 38.2 & 39.7 & \\
\hline Yankeetown, Fla. (Sept. 3-7, 1950) & & & & 38.7 & 43.1 & 45.2 \\
\hline Manatt Ranch (Aug. 1-3, 1978) & & & & & & $>48$ ( 52 \\
\hline Cilaos, La Reunion (Mar. 15-18, 1952) & & & & 73.62 & 98.42 & 127.56 \\
\hline
\end{tabular}




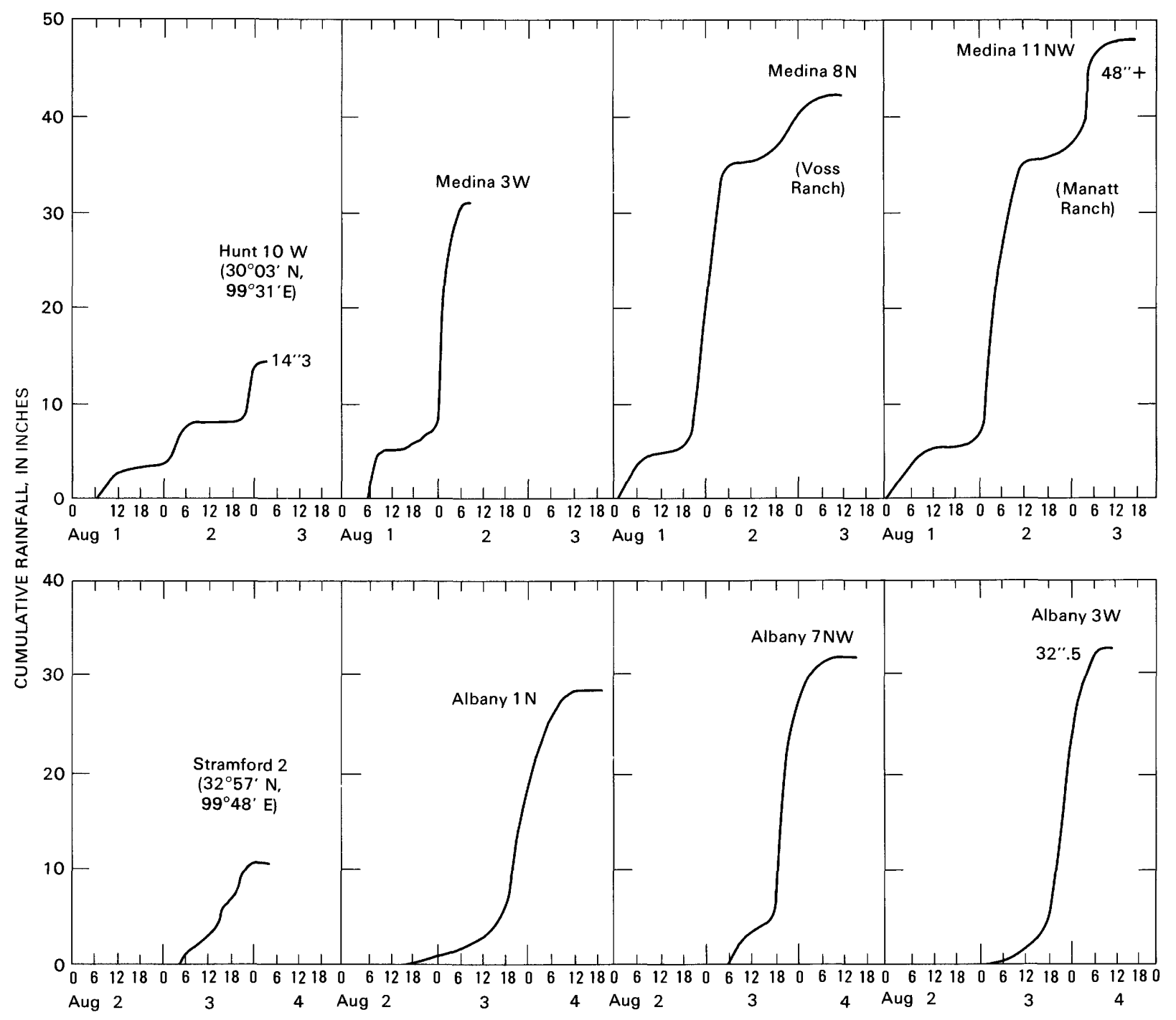

FIGURE 12.-Mass rainfall curves at selected rain gages, August 1-4. 1978.

in the Indian Ocean, where elevations rise to $10,000 \mathrm{ft}$ in 10-15 mi from the shore (Paulhus, 1965).

Rainfall extremes set the very lowest limit to estimates of probable maximum precipitation (PMP). The record of more than 48 in. observed during August 1-3, 1978, $11 \mathrm{mi}$ northwest of Medina in the hill country reached 95 percent of the all-season probable maximum precipitation (PMP) for 72 hours and $10 \mathrm{mi}^{2}$ at that location (Schreiner and Riedel, 1978) and will constitute important input in future PMP studies.

\section{DESCRIPTION OF THE FLOODS}

Flooding to some degree occurred in an area of approximately $25,000 \mathrm{mi}^{2}$ in parts of the Nueces, Guadalupe, Colorado, and Brazos River basins. A summary of flood stages and discharges for selected sites is given in table 4; the locations of the sites are shown in figure 1 . The locations of discontinued streamgaging stations and miscellaneous discharge-measurement sites are given in table 5.

\section{NUECES RIVER BASIN}

During the early part of the storm on August 1, substantial rain fell on the headwaters of the Sabinal River, Hondo Creek, and Seco Creek in the Nueces River basin. The greatest 24-hour amount recorded by the National Weather Service in this basin was at Vanderpool in Bandera County, where a total of $11.53 \mathrm{in}$. fell in the 24-hour period ending at 0700 August 2. Sharp rises occurred on many streams, but flooding was minor. 
DESCRIPTION OF THE FLOODS

TABLE 4.-Summary of flood stages and discharges

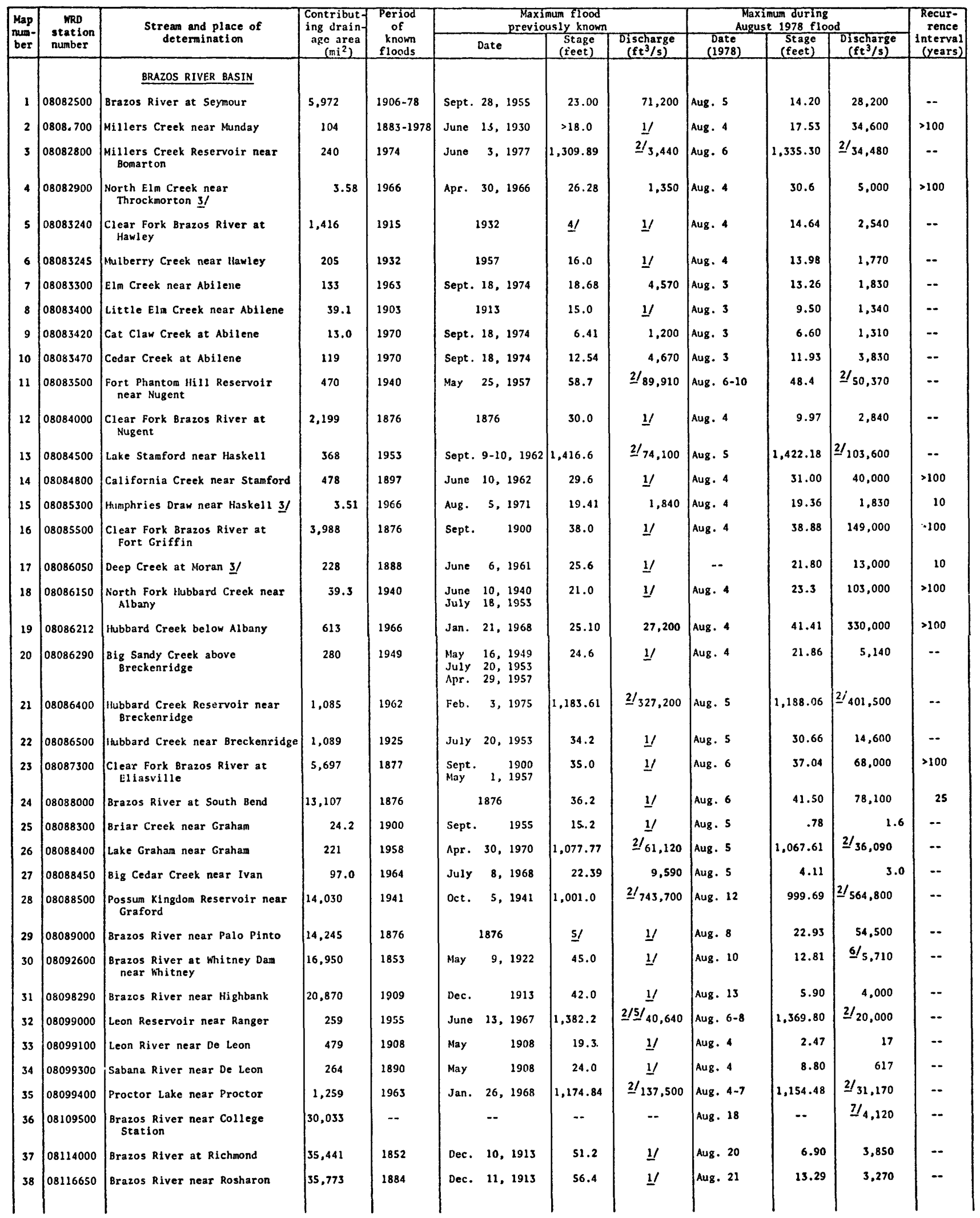

See footnotes at end of table. 
TABLE 4.-Summary of flood stages and discharges-Continued

\begin{tabular}{|c|c|c|c|c|c|c|c|c|c|c|c|c|}
\hline \multirow{2}{*}{$\begin{array}{l}\text { Map } \\
\text { num- } \\
\text { ber }\end{array}$} & \multirow{2}{*}{$\begin{array}{l}\text { WRD } \\
\text { station } \\
\text { number }\end{array}$} & \multirow{2}{*}{$\begin{array}{l}\text { Stream and place of } \\
\text { deternination }\end{array}$} & \multirow{2}{*}{$\begin{array}{c}\text { Contribut- } \\
\text { ing drain- } \\
\text { age area } \\
\left(\mathrm{mi}^{2}\right)\end{array}$} & \multirow{2}{*}{$\begin{array}{l}\text { Period } \\
\text { of } \\
\text { known } \\
\text { floods }\end{array}$} & \multicolumn{4}{|c|}{$\begin{array}{l}\text { Mlaximum flood } \\
\text { previously known }\end{array}$} & \multicolumn{3}{|c|}{$\begin{array}{l}\text { Maximum during } \\
\text { August } 1978 \text { flood }\end{array}$} & \multirow{2}{*}{$\begin{array}{c}\text { Recur- } \\
\text { rence } \\
\text { interval } \\
\text { (years) }\end{array}$} \\
\hline & & & & & & Date & $\begin{array}{c}\text { Stage } \\
\text { (feet) }\end{array}$ & $\begin{array}{l}\text { Discharge } \\
\left(\mathrm{ft}^{3} / \mathrm{s}\right)\end{array}$ & $\begin{array}{l}\text { Date } \\
(1978)\end{array}$ & $\begin{array}{c}\text { Stage } \\
\text { (feet) }\end{array}$ & $\begin{array}{c}\begin{array}{c}\text { Discharge } \\
\left(\mathrm{ft}^{3} / \mathrm{s}\right)\end{array} \\
\end{array}$ & \\
\hline & & COLORADO RIVER BASIN & & & & & & & & & & \\
\hline 39 & 08126500 & Colorado River at Ballinger & 5,240 & 1882 & & 1884 & 36.0 & $\underline{1 /}$ & Aug. 3 & 23.95 & 16,600 & -- \\
\hline 40 & 08127000 & Elm Creek at Ballinger & 471 & 1904 & $\begin{array}{l}\text { Aug. } \\
\text { Oct. }\end{array}$ & 13, $\begin{array}{r}1906 \\
1957\end{array}$ & $\begin{array}{r}8 / 14.50 \\
14.20\end{array}$ & $\frac{1 /}{50,000}$ & Aug. 3 & 9.17 & 23,400 & 15 \\
\hline 41 & 08136500 & Concho River at Paint Rock & 5,132 & 1853 & Sept. & 17,1936 & 43.4 & 301,000 & Aug. 3 & 19.11 & 12,700 & -- \\
\hline 42 & 08136700 & Colorado River near Stacy & 11,160 & 1882 & Sept. & 18,1936 & 64.59 & 356,000 & Aug. 4 & 22.50 & 35,700 & -- \\
\hline 43 & 08138000 & Colorado River at Winchell & 11,700 & 1882 & Sept. & 19,1936 & 62.20 & 11 & Aug. 5 & 31.88 & 29,600 & -- \\
\hline 44 & 08140600 & Lake Clyde near Clyde & 37.9 & 1970 & May & 28,1975 & $1,873.4$ & $2 / 6,370$ & Aug. 4 & $1,875.50$ & $2 / 7,420$ & -- \\
\hline 45 & 08140700 & Pecan Bayou near Cross Cut & 532 & 1900 & & 1908 & 26.5 & $\underline{1 /}$ & Aug. 4 & 24.90 & 16.200 & \\
\hline 46 & 08140800 & Jim Ned Creek near Coleman & 333 & 1961 & May & 6. 1969 & 9.08 & 5,020 & Aug. 4 & 5.77 & 1,830 & -- \\
\hline 47 & 08141000 & Hords Creek Lake near Valera & 48 & 1948 & May & 1, 1956 & $1,906.86$ & $2 / 12,790$ & Aug. 5 & $1,887.90$ & $2 / 3,570$ & -- \\
\hline 48 & 08141500 & librds Creek near valera & 53 & 1900 & July & 3,1932 & 23.0 & $\underline{11}$ & Aug. 3 & 11.06 & 2.360 & -- \\
\hline 49 & 08143000 & Lake Brownwood near Brownwood & 1,535 & 1933 & May & 2,1956 & $1,431.4$ & $2 / 192,300$ & Aug. $\begin{array}{l}16-24, \\
29,30\end{array}$ & $1,424.4$ & $2 / 138,500$ & -- \\
\hline 50 & 08143500 & Pecan Bayou at Brownwood & 1,614 & 1900 & July & 3, 1932 & -- & $9 / 235,000$ & Aug. 4 & 1.05 & 47 & $\cdots$ \\
\hline 51 & 08143600 & Pecan Bayou near Mullin & 2,034 & 1967 & Jan. & 23,1968 & 29.26 & 13,700 & Aug. 3 & 6.50 & 1,690 & $\cdots$ \\
\hline 52 & 08144500 & San Saba River at Menard & 1,151 & 1880 & June & 6,1899 & 23.3 & $\underline{y}$ & Aug. 2 & 17.36 & 35,400 & 25 \\
\hline 53 & 08144800 & Brady Creek near Eden & 97 & 1884 & July & 1938 & 15.8 & $\underline{11}$ & Aug. 3 & 1.3 & 2.1 & -- \\
\hline 54 & 08144900 & $\begin{array}{l}\text { Brady Creek Reservoir near } \\
\text { Brady }\end{array}$ & 513 & 1963 & Sept. & 24,1971 & $1,747.7$ & $2 / 40,880$ & Aug. 3 & $1,738.12$ & $2 / 21,570$ & -- \\
\hline 55 & 08145000 & Brady Creek at Brady & 575 & 1882 & July & 23,1938 & 29.1 & 86,000 & Aug. 2 & 8.31 & 536 & $\cdots$ \\
\hline 56 & 08146000 & San Saba River at San Saba & 3,042 & 1899 & July & 23,1938 & 39.3 & 203,000 & Aug. 3 & 28.38 & 27,000 & -- \\
\hline 57 & 08147000 & Colorado River near San Saba & 17,720 & 1878 & July & 23,1938 & 63.2 & 224,000 & Aug. 4 & 22.59 & 28,100 & -- \\
\hline 58 & 08148000 & Lake Buchanan near Burnet & 18,370 & 1937 & Jan. & 24,1968 & $1,020.8$ & $2 / 1,010,000$ & Aug. 8 & $1,011.94$ & $2 / 814,700$ & \\
\hline 59 & -. & $\begin{array}{l}\text { Bear Creek at Interstate High- } \\
\text { way } 10 \text { near Junction } 10 /\end{array}$ & 155 & 1936 & Sept. & 16,1936 & -- & 31,300 & Aug. 3 & -- & 81,000 & -- \\
\hline 60 & 08148500 & $\begin{array}{l}\text { North } L 1 \text { ano River near } \\
\text { Junction } \underline{3}\end{array}$ & 914 & 1875 & Sept. & 16,1936 & 29.2 & 94,800 & Aug. 2 & 23.50 & 64,800 & 10 \\
\hline 61 & 08150000 & Llano River near Junction & 1,874 & 1875 & June & 14,1935 & 43.3 & 319,000 & Aug. 2 & 22.14 & 76,700 & -- \\
\hline 62 & 08150700 & Llano River near Mason & 3.280 & 1875 & June & 14,1935 & -- & $11 / 388,000$ & Aug. 3 &, 21.35 & 92,500 & -. \\
\hline 63 & 08150800 & Beaver Creek near Mason & 218 & 1963 & May & 16,1965 & 13.58 & 23,200 & Aug. 3 & 24.00 & 66,900 & $>100$ \\
\hline 64 & 08151500 & Llano River at Llano & 4,233 & 1879 & June & 14,1935 & 41.5 & 380,000 & Aug. 3 & 25.61 & 139.000 & 15 \\
\hline 65 & 08152000 & Sandy Creek near Kingsland & 327 & 1881 & Sept. & 11,1952 & 34.2 & 163,000 & Aug. 2 & 8.89 & 3,610 & -- \\
\hline 66 & 08152800 & $\begin{array}{l}\text { Spring Creek near Fredericks- } \\
\text { burg } 3 /\end{array}$ & 15.2 & 1967 & Aug. & 28,1974 & 8.42 & 7,530 & Aug. 3 & 17.0 & 42,500 & $>100$ \\
\hline 67 & 08153100 & Cane Branch at Stonewall $\underline{3}$ & 1.37 & -- & & -- & -- & -- & Aug. 3 & -- & $<10$ & -- \\
\hline 68 & 08153500 & $\begin{array}{l}\text { Pedernales River near Johnson } \\
\text { City }\end{array}$ & 947 & 1859 & Sept. & 11,1952 & 42.5 & 441,000 & Aug. 3 & 24.9 & 127,000 & 25 \\
\hline 69 & 08154500 & $\begin{array}{l}\text { Lake Travis near Aust in } \\
\text { GUADAWPE RIVER BASIN }\end{array}$ & 25,250 & 1940 & May & 18,1957 & 707.4 & $2 / 1,770,000$ & Aug. 4 & 662.9 & $2 / 868,200$ & -. \\
\hline 70 & 08165300 & $\begin{array}{l}\text { North Fork Guadalupe River near } \\
\text { Hunt }\end{array}$ & 168 & 1900 & July & 1,1932 & 37.3 & 140,000 & Aug. 3 & 26.8 & 39,300 & - \\
\hline 71 & 08165500 & Guadalupe River at Hunt & 288 & 2900 & July & 2,1932 & 36.6 & 206,000 & Aug. 2 & 23.5 & 62,900 & 10 \\
\hline 72 & 08166000 & Johnson Creek near Ingram & 114 & 1852 & July & 2,1932 & 35.0 & 138,000 & Aug. 3 & 21.4 & 73.900 & 60 \\
\hline 73 & -- & $\begin{array}{l}\text { Turtle Creek at State Highway } \\
\text { 16 near Kerrville 10/ }\end{array}$ & 26.5 & $\cdots$ & & -- & -- & -. & Aug. 2 & -- & 32,700 & -- \\
\hline 74 & 08166300 & $\begin{array}{l}\text { Turtle Creek tributary near } \\
\text { Kerrville } 3 /\end{array}$ & .46 & .. & & $\cdots$ & -- & -- & -- & 11.2 & 605 & -- \\
\hline 75 & 08167000 & Guadalupe River at Comfort & 838 & 1848 & July & 1869 & 40.3 & $\underline{1 /}$ & Aug. 2 & 40.9 & 240,000 & $>100$ \\
\hline 76 & 08167500 & $\begin{array}{l}\text { Guadalupe River near Spring } \\
\text { Branch }\end{array}$ & 1,315 & 1859 & & 1869 & 53.0 & $\underline{y}$ & Aug. 3 & 45.25 & 158,000 & $>100$ \\
\hline
\end{tabular}

See footnotes at end of table. 
DESCRIPTION OF THE FLOODS

TABLE 4.-Summary of flood stages and discharges-Continued

\begin{tabular}{|c|c|c|c|c|c|c|c|c|c|c|c|c|}
\hline \multirow{2}{*}{$\begin{array}{l}\text { Map } \\
\text { num- } \\
\text { ber }\end{array}$} & \multirow{2}{*}{$\begin{array}{l}\text { MRD } \\
\text { station } \\
\text { number }\end{array}$} & \multirow{2}{*}{$\begin{array}{l}\text { Stream and place of } \\
\text { determination }\end{array}$} & \multirow{2}{*}{$\begin{array}{c}\text { Contribut } \\
\text { ing Jrain- } \\
\text { age area } \\
\left(\mathrm{mi}^{2}\right)\end{array}$} & \multirow{2}{*}{$\begin{array}{c}\text { Period } \\
\text { of } \\
\text { known } \\
\text { floods }\end{array}$} & \multicolumn{4}{|c|}{$\begin{array}{l}\text { Maximum flood } \\
\text { previously known }\end{array}$} & \multicolumn{3}{|c|}{$\begin{array}{l}\text { Maximun during } \\
\text { August } 1978 \text { flood }\end{array}$} & \multirow{2}{*}{$\begin{array}{r}\text { Recur- } \\
\text { rence } \\
\text { interval } \\
\text { (years) }\end{array}$} \\
\hline & & & & & & Date & $\begin{array}{r}\text { Stage } \\
\text { (feet) }\end{array}$ & $\begin{array}{l}\text { Discharge } \\
\left(\mathrm{ft}^{3} / \mathrm{s}\right)\end{array}$ & $\begin{array}{l}\text { Date } \\
(1978) \\
\end{array}$ & $\begin{array}{r}\text { Stage } \\
\text { (feet) }\end{array}$ & $\begin{array}{c}\text { Discharge } \\
\left(\mathrm{ft}^{3} / \mathrm{s}\right)\end{array}$ & \\
\hline 77 & 08167600 & $\begin{array}{l}\text { Rebecca Creek near Spring } \\
\text { Branch }\end{array}$ & 10.9 & 1885 & Sept. & - 1952 & 25.5 & $\underline{1 /}$ & Aug. 1 & 2.06 & 1.5 & -- \\
\hline 78 & 08167700 & Canyon Lake near New Braunfels & 1,432 & 1962 & Apr. & 22,1977 & 917.96 & $2 / 460,400$ & Aug. 4 & $12 / 930.61$ & $2 / 588,400$ & -- \\
\hline 79 & 08167800 & Cuadalupe River at Sattler & 1,436 & 1962 & Feb. & 11,1975 & 8.18 & $13 / 5,390$ & Aug. 5 & 8.31 & 5,850 & -- \\
\hline 80 & -- & $\begin{array}{l}\text { North Prong Medina River near } \\
\text { Medina } 10\end{array}$ & 67.5 & 1932 & July & 1,1932 & -- & 40,200 & Aug. 2 & - & 123,000 & $\rightarrow$ \\
\hline 81 & 08178900 & $\begin{array}{l}\text { Bandera Creek tributary near } \\
\text { Bandera } 3 /\end{array}$ & .27 & -- & & -- & -- & -- & Aug. 2 & 10.9 & 120 & -- \\
\hline 82 & 08179000 & Medina River near Pipe Creek & 474 & 1880 & & 1919 & 43.0 & $14 / 115,000$ & Aug. 2 & 49.6 & 281,000 & $>100$ \\
\hline 83 & 08179100 & Red Bluff Creek near Pipe Creek & 56.3 & 1905 & Sept. & 27,1964 & 22.64 & 46,900 & Aug. 2 & 3.7 & 160 & -- \\
\hline 84 & 08179500 & Medina Lake near San Antonio & 634 & 1913 & Sept. & 16,1919 & $1,078,0$ & $\underline{2} / 288,000$ & Aug. 2 & $1,076,67$ & $2 / 281,000$ & - \\
\hline 85 & 08180500 & Medina River near Rio Medina $\underline{3}$ & 650 & 1922 & July & 15,1973 & 23.2 & 28,600 & Aug. 2 & 20.0 & 20,100 & -- \\
\hline 86 & 08180800 & Medina River near Somerset & 967 & 1890 & July & 17,1973 & 29.39 & 30,500 & Aug. 4 & 22.35 & 12,800 & -- \\
\hline 87 & 08181500 & Medina River at San Antonio & 1,317 & 1939 & July & 17,1973 & 43.59 & 31,900 & Aug. 4 & 29.95 & 1,030 & -- \\
\hline 88 & 08183900 & $\begin{array}{r}\text { Cibolo Creek near Boerne } \\
\text { NUECES RIVER BASIN }\end{array}$ & 68.4 & 1892 & Sept. & 27,1964 & 19.15 & 36,400 & Aug. 2 & 3.65 & 462 & -- \\
\hline 89 & 08195000 & Frio River at Concan & 405 & 1869 & July & 1,1932 & 34.44 & 162,000 & Aug. 2 & 6.9 & 3,350 & -- \\
\hline 90 & 08196000 & $\begin{array}{l}\text { Dry Frio River near Reagan } \\
\text { Wells }\end{array}$ & 117 & 1875 & & 1880 & 33.0 & $\underline{1 /}$ & Aug. 1 & 5.23 & 1,500 & -- \\
\hline 91 & 08198000 & S1binal River near Sabinal & 206 & 1892 & July & 2,1932 & 33.0 & $\underline{1}$ & Aug. 2 & 19.43 & 23,200 & -- \\
\hline 92 & 08200000 & Hondo Creek near Tarpley & 86.2 & 1907 & June & 17,1958 & 28.2 & 69,800 & Aug. 2 & 13.10 & 13,200 & - \\
\hline 93 & 08201500 & $\begin{array}{l}\text { Seco Creek at Miller Ranch near } \\
\text { Utopia }\end{array}$ & 43.1 & 1901 & June & 17,1958 & 16.4 & 52,600 & Aug. 2 & 8.40 & 10,600 & -- \\
\hline
\end{tabular}

$1 /$ Discharge not determined.

2/ Contents in acre-feet.

$3 /$ Discontinued site, see table 2 .

$4 /$ The maximum stage since 1915 occurred in 1932 and the second highest stage occurred in $1959,2,510$ feet.

5/ The maximum stage occurred in 1876 and was several feet higher than

flood of June $16,1930,30$ feet, $95,600 \mathrm{ft}^{3} / \mathrm{s}$.

6/ Stage and discharge data at site 08093100 .

I/ At site 6.5 miles downstream.

\section{GUADALUPE RIVER BASIN}

The drainage area of the Guadalupe River above Canyon Lake received the first of the heavy rainfall during the night of August 1 and the morning of August 2. The storm cell, which was centered just west of Kerrville in Kerr County, produced rainfall amounts that resulted in severe flooding on the Guadalupe River and all of its local tributaries. On August 2, the flood crest on the Guadalupe River at Comfort (site 75 , fig. 1) exceeded by $0.6 \mathrm{ft}$ the previously known maximum, which occurred in July 1869. When the crest reached the Spring Branch gaging station (site 76) on August 3 , the peak discharge had attentuated from $240,000 \mathrm{ft}^{3} / \mathrm{s}$ at Comfort to $160,000 \mathrm{ft}^{3} / \mathrm{s}$ at Spring Branch. Secondary peaks occurred at both stations. A discharge hydrograph for Guadalupe River at Comfort is shown in figure 15, and data are presented in table 6 . A discharge hydrograph for Guadalupe River near Spring Branch is shown in figure 16, and data are presented in table 7 .

Canyon Lake contained all of the flood runoff from the Guadalupe River basin above the dam, so no damage occurred
8/ Backwater from Colorado River.

$\overline{9} /$ Prior to completion of Lake Brownwood.

$1 \overline{0} /$ Niscellaneous site, see table 2 .

$\frac{11 /}{12}$ At site 17 miles downstream.

$\frac{12 /}{12 /}$ Elevation at 2400 hours.

$\frac{13}{13}$ Maximum since closure of Canyon Dam on July 21, 1962.

14/ From rating extended above $32,000 \mathrm{ft}^{3} / \mathrm{s}$ on basis of slope-area measurement of $64,000 \mathrm{ft}^{3} / \mathrm{s}$.

below Canyon Lake. The contents of Canyon Lake increased from 362,200 acre-ft at 2400 August 1 to 588,400 acre-ft at 2400 August 4 . This was the maximum storage since closure of the dam on July 21, 1962.

\section{MEDINA RIVER BASIN}

A second cell of the storm that caused flooding in the Guadalupe River basin was centered near Medina in Bandera County where the North Prong and the West Prong of the Medina River join. The official total rainfall near the storm's center was in excess of $48 \mathrm{in}$., which resulted in a catastrophic flood on the headwaters of the Medina River. A peak discharge of $123,000 \mathrm{ft}^{3} / \mathrm{s}$ from a drainage area of $67.5 \mathrm{mi}^{2}$ was recorded at a miscellaneous site (site 80 ) on the North Prong Medina River about $10 \mathrm{mi}$ upstream from Medina. The maximum flood discharge probably occurred a short distance downstream from the confluence of the North Prong and West Prong of Medina River. 


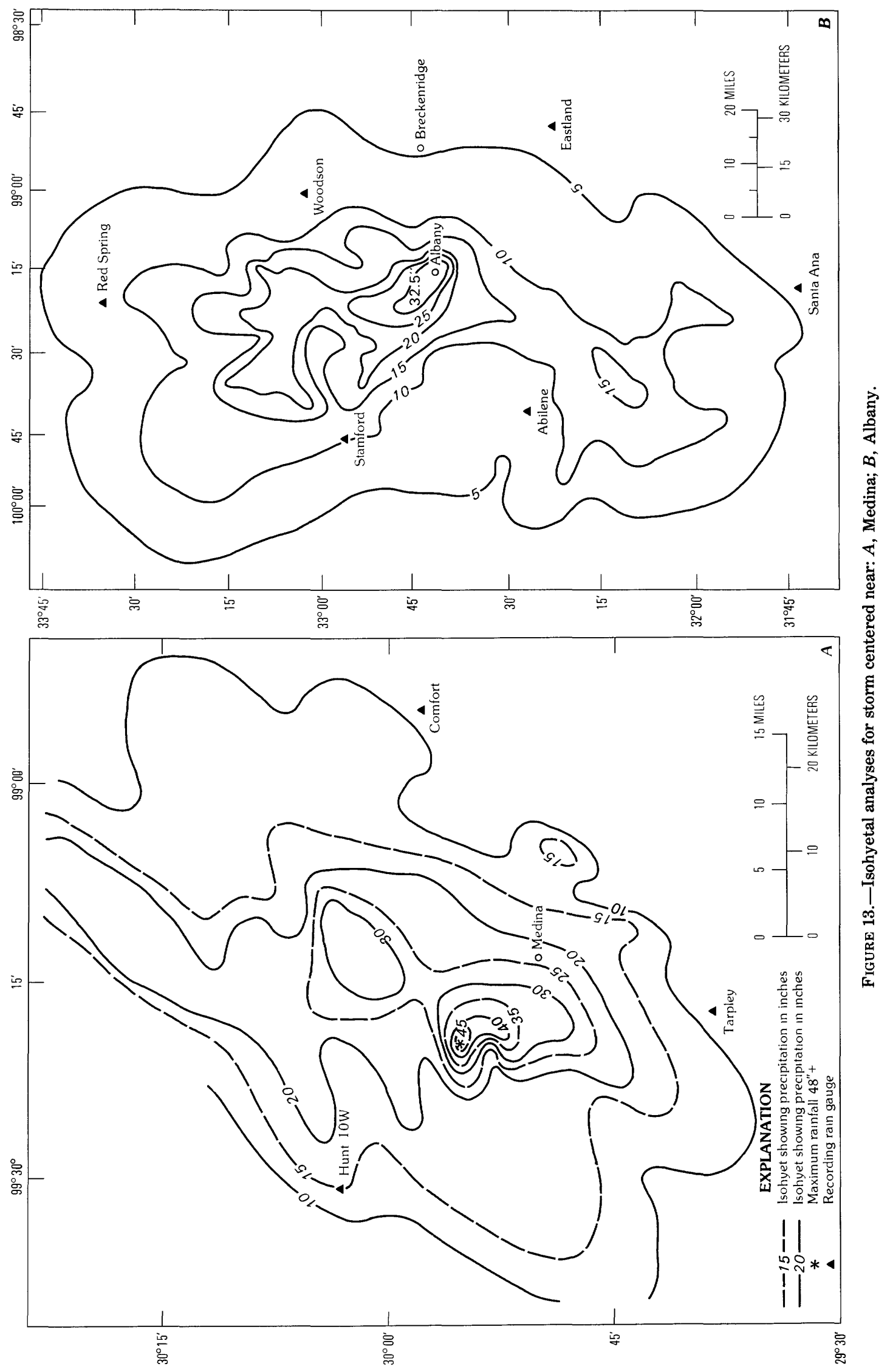


TABLE 5.-Locations of discontinued stream-gaging stations and miscellaneous discharge-measurement sites

\begin{tabular}{lll}
\hline $\begin{array}{c}\text { Map } \\
\text { number }\end{array}$ & $\begin{array}{l}\text { Station } \\
\text { number }\end{array}$ & Name and location \\
\hline
\end{tabular}

\section{BRAZOS RIVER BASIN}

408082900 North Elm Creek near Throckmorton. Lat $33^{\circ} 10^{\prime} 50^{\prime \prime}$, long $99^{\circ} 22^{\circ} 05$, Throckmorton County,
Hydrologic Unit 12060101 , at culvert on State Highway 24 , and $11.3 \mathrm{miles}$ (18.2 kilometers) west of Throckmorton.

150 08085300 Humphries Draw near Haske11. Lat $33^{\circ} 10^{\prime} 40^{\prime \prime}$, Iong $99^{\circ} 34^{\prime} 30^{\prime \prime}$, Haskell County, Hydrologic Unit 12060101, at culvert on State Highway 24 , and 9.3 miles ( 15.0 kilometers) east of Haskell.

$17 \quad 08086050$

Deep Creek at Moran. Lat $32^{\circ} 33^{\prime} 33^{\prime \prime}$, long $99^{\circ} 10^{\prime} 11^{\prime \prime}$, Shackelford County, Hydrologic Unit 12060105, at downstream side of bridge on U.S. Highway $380,0.8 \mathrm{mile}$ (1.3 kilometer) north of Moran, and $10.8 \mathrm{miles}(17.4 \mathrm{ki}$ lometers) upstream from Hubbard Creek.

\section{COLORADO RIVER BASIN}

Bear Creek at Interstate Highway 10 near Junction. Lat $30^{\circ} 31^{\prime} 57^{\prime \prime}$, long $99^{\circ} 50^{\prime} 11^{\prime \prime}$, Kimble County, Hydrologic Unit $12090202,1.3$ miles (2.1 kilometers) upstream from Interstate Highway $10,1.5$ miles $(2.4$ kilometers) upstream from mouth, and $3.4 \mathrm{miles}$ (5.5 kilometers) west of Junction.

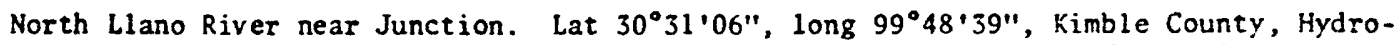
logic Unit $12090202,1,000$ feet (305 meters) upstream from remains of old Wilson Dam, 2.1 miles ( 3.4 kilometers) northwest of Junction, and 4 miles ( 6 kilometers) upstream from confluence with South Llano River.

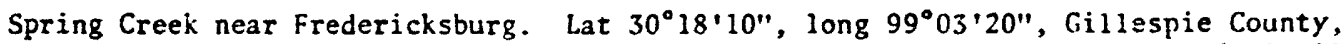
Hydrologi: Unit 12090206, downstrear side of bridge on U.S. Highway 290, and 11 miles (18 kilometers) west of Fredericksburg.

$67 \quad 08153100$

Cane Branch at Stonewall. Lat $30^{\circ} 14^{\prime} 07^{\prime \prime}$, long $98^{\circ} 39^{\prime} 21^{\prime \prime}$, Gillespie County, Hydrologic Unit 12090206, at culvert on U.S. Highway 290 at Stonewall, and $0.6 \mathrm{milc}$ (1.0 kilometer) upstream from Pedernales River.

\section{GUADALUPE RIVER BASIN}

73

74

80

81

85
08166300

Turtle Creek at State Highway 16 near Kerrville. Lat $29^{\circ} 57^{\prime} 41^{\prime \prime}$, long $99^{\circ} 12^{\prime} 35^{\prime \prime}$, Kerr County, Hydrologic Unit $12100201,0.1 \mathrm{mile}(0.2 \mathrm{kilometer})$ upstream from Lambs Creek, at State Highway 16 and 9.0 miles (14.5 kilometers) southwest of Kerrville.

Turtle Creek tributary near Kerrville. Lat $29^{\circ} 58^{\prime} 11^{\prime \prime}$, Iong $99^{\circ} 11^{\prime} 02^{\prime \prime}$, Kerr County, Hydrologic Unit 12100201, at culvert on Farm Road 2771 , and 5.9 miles ( 9.5 kilometers) south of Kerrville.

North Prong Medina River near Medina. Lat $29^{\circ} 51^{\prime} 49^{\prime \prime}$, long $99^{\circ} 22^{\prime} 18^{\prime \prime}$, Bandera County, Hydrologic Unit $12100302,0.5$ mile $(0.8$ kilometer) upstream from Lima School, and 12.0 miles (19.3 kilometers) upstream from mouth.

08178900 Bandera Creek tributary near Bandera. Lat $29^{\circ} 50^{\prime} 51^{\prime \prime}$, long $99^{\circ} 06^{\prime} 12^{\prime \prime}$, Bandera County, Hydrologic Unit 12100302, at culvert on Farm Road 689, and 10 miles (16 kilometers) north of Bandera.

08180500 Medira River near Rio Medina. Lat $29^{\circ} 29^{\prime} 53^{\prime \prime}$, long $98^{\circ} 54^{\prime} 16^{\prime \prime}$, Medina County, Hydrologic Unit 12100302, on left bank 233 feet (71 meters) upstream from bridge at Hahy's crossing, 4.2 miles $(6.8 \mathrm{ki}$ lometers $)$ northwest of Rio Medina, and $10.4 \mathrm{miles}(16.7$ kilometers) upstream from San Geronimo Creek. 
TABLE 6. - Data for gaging station 08167000 Guadalupe River at Comfort [Gage height, in feet, and discharge, in cubic feet per second, at indicated time, 1978]

\begin{tabular}{|c|c|c|c|c|c|c|c|c|c|c|c|}
\hline Date & Hour & $\begin{array}{c}\text { Gage } \\
\text { height }\end{array}$ & Discharge & Date & Hour & $\begin{array}{c}\text { Gage } \\
\text { height }\end{array}$ & Discharge & Date & Hour & $\begin{array}{c}\text { Gage } \\
\text { height }\end{array}$ & Discharge \\
\hline \multirow[t]{2}{*}{ Aug. } & $\begin{array}{l}0900 \\
1500 \\
1600 \\
1700 \\
1800 \\
1900 \\
2400\end{array}$ & $\begin{array}{r}4.10 \\
4.14 \\
4.36 \\
6.12 \\
8.25 \\
9.85 \\
11.26\end{array}$ & $\begin{array}{r}50 \\
56 \\
103 \\
1,040 \\
1,990 \\
2,760 \\
3,580\end{array}$ & \multirow[t]{2}{*}{ Aug. 2 - } & $\begin{array}{r}-1000 \\
1100 \\
1200 \\
1500 \\
1800 \\
2100 \\
2400\end{array}$ & $\begin{array}{l}38.82 \\
36.07 \\
34.19 \\
30.89 \\
26.23 \\
21.36 \\
17.58\end{array}$ & $\begin{array}{r}203,000 \\
161,000 \\
137,000 \\
98,600 \\
56,400 \\
28,000\end{array}$ & Aug. 3 & $\begin{array}{r}-1400 \\
1600 \\
1800 \\
2100 \\
2400\end{array}$ & $\begin{array}{l}27.83 \\
23.67 \\
19.87 \\
16.45 \\
14.52\end{array}$ & $\begin{array}{r}69,200 \\
39,900 \\
21,700 \\
12,000 \\
7,870\end{array}$ \\
\hline & 2400 & 11.26 & 3,580 & & 2400 & 17.58 & 14,600 & \multirow{2}{*}{\multicolumn{2}{|c|}{$\begin{array}{r}\text { Aug. } 4-0600 \\
1200 \\
2400\end{array}$}} & \multirow{2}{*}{$\begin{array}{r}12.31 \\
10.88 \\
9.00\end{array}$} & \multirow{2}{*}{$\begin{array}{l}4,520 \\
3,330 \\
2,340\end{array}$} \\
\hline \multirow[t]{4}{*}{ Aug. 2 - } & $\begin{array}{l}0300 \\
0400\end{array}$ & $\begin{array}{l}11.74 \\
13.24\end{array}$ & $\begin{array}{l}3,960 \\
5,710\end{array}$ & Aug. 3 & $\begin{array}{r}0300 \\
0500\end{array}$ & $\begin{array}{l}15.20 \\
19.38\end{array}$ & $\begin{array}{r}9,260 \\
20,100\end{array}$ & & & & \\
\hline & $\begin{array}{l}0500 \\
0600\end{array}$ & $\begin{array}{l}15.85 \\
22.97\end{array}$ & $\begin{array}{l}10,700 \\
36,000\end{array}$ & & $\begin{array}{l}0600 \\
0700\end{array}$ & $\begin{array}{l}30.76 \\
33.98\end{array}$ & $\begin{array}{r}97,200 \\
134,000\end{array}$ & \multirow[t]{2}{*}{ Aug. 5} & $\begin{array}{r}-1200 \\
2400\end{array}$ & $\begin{array}{l}8.00 \\
7.49\end{array}$ & $\begin{array}{l}1,770 \\
1,450\end{array}$ \\
\hline & 0700 & 30.98 & 99,500 & & 0800 & 35.08 & 148,000 & & & & \\
\hline & $\begin{array}{l}0800 \\
0900\end{array}$ & $\begin{array}{l}37.55 \\
40.90\end{array}$ & $\begin{array}{l}183,000 \\
240,000\end{array}$ & & $\begin{array}{l}0900 \\
1100\end{array}$ & $\begin{array}{l}34.87 \\
33.00\end{array}$ & $\begin{array}{l}145,000 \\
122,000\end{array}$ & Aug, 6 & $\begin{array}{r}-1200 \\
2400\end{array}$ & $\begin{array}{l}7.18 \\
7.04\end{array}$ & $\begin{array}{l}1,260 \\
1,170\end{array}$ \\
\hline
\end{tabular}

\begin{tabular}{|c|c|c|c|}
\hline Period & 1 & $\begin{array}{l}\text { ge, in cubic feet per second, } \\
\text { number of consecutive days } \\
3\end{array}$ & , \\
\hline August 1978 & 74,200 & 44,400 & 19,800 \\
\hline 1940 to July 1978 & 27,300 & 13,700 & 6,840 \\
\hline
\end{tabular}

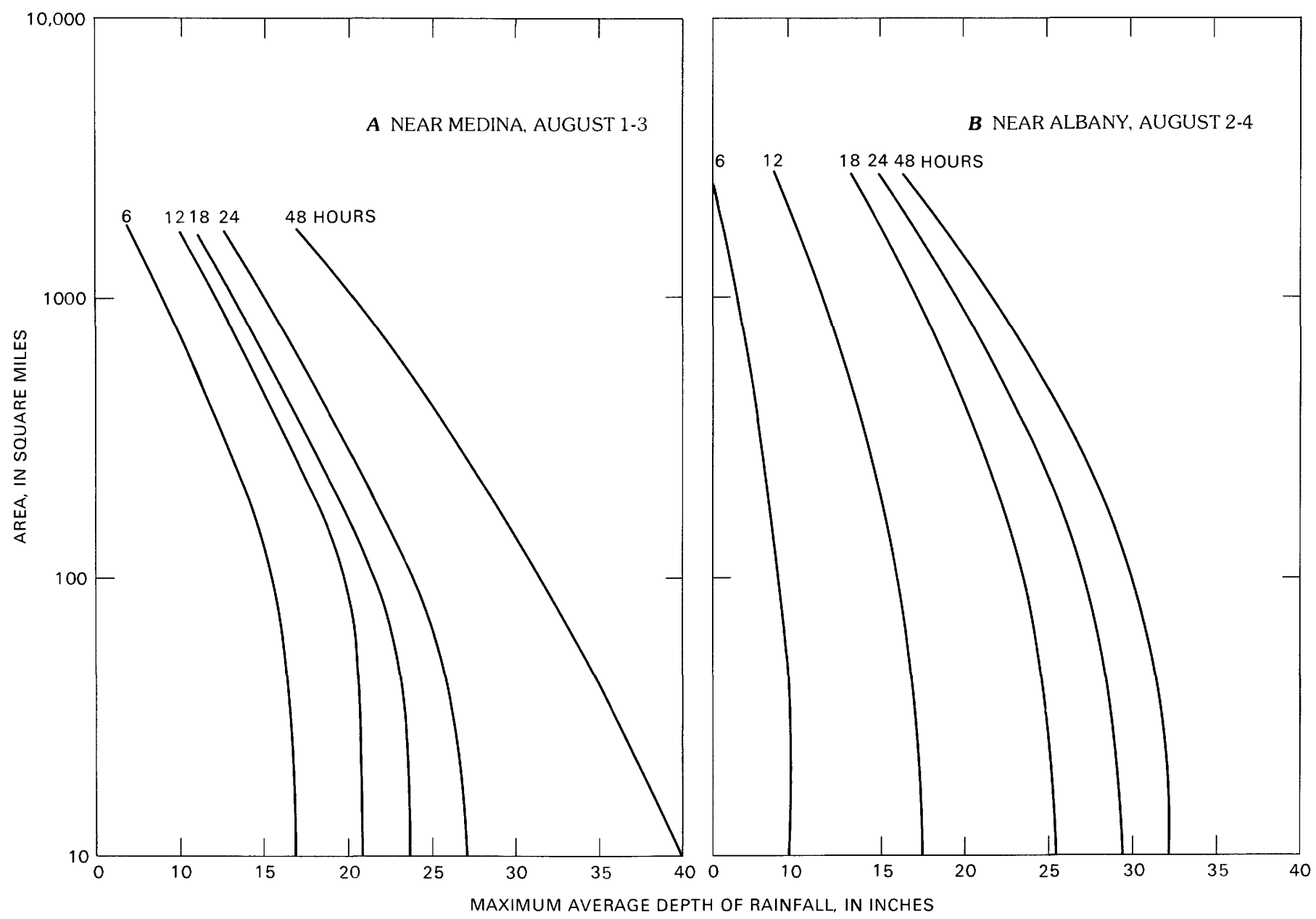

FIGURE 14.-Depth-area duration analysis for storm centered near: $A$, Medina; $B$, Albany. 
TABLE 7.-Data for gaging station 08167500 Guadalupe River near Spring Branch

[Gage height, in feet, and discharge, in cubic feet per second, at indicated time, 1978]

\begin{tabular}{|c|c|c|c|c|c|c|c|c|c|c|c|}
\hline Date & Hour & $\begin{array}{l}\text { Gage } \\
\text { height }\end{array}$ & Discharge & Date & Hour & $\begin{array}{l}\text { Gage } \\
\text { height }\end{array}$ & Discharge & Date & Hour & $\begin{array}{l}\text { Gage } \\
\text { height }\end{array}$ & Discharge \\
\hline \multirow[t]{4}{*}{ Aug. 1 - } & -0300 & 2.20 & 40 & Aug. 2 & 2400 & 34.00 & 54,400 & \multirow[t]{8}{*}{ Aug. 4} & -0200 & 40.60 & 118,000 \\
\hline & 1200 & 2.37 & 64 & & & & & & 0300 & 39.40 & 108,000 \\
\hline & 2400 & 2.55 & 95 & Aug. 3 & -0100 & 37.80 & 94,500 & & 0800 & 32.30 & 56,300 \\
\hline & & & & & 0200 & 42.00 & 130,000 & & 1200 & 27.80 & 36,400 \\
\hline \multirow{10}{*}{ Aug. 2 - } & -0300 & 2.57 & 39 & & 0300 & 45.25 & ח & & 1600 & 21.40 & 21,300 \\
\hline & 0500 & 2.77 & 144 & & 0400 & 44.10 & 152,000 & & 2000 & 14.00 & 10,400 \\
\hline & 1000 & 3.07 & 232 & & 0800 & 38.00 & 96,100 & & 2400 & 11.00 & 6,920 \\
\hline & 1100 & 3.90 & 611 & & 1200 & 32.70 & 58,800 & & & & \\
\hline & 1200 & 5.10 & 1,290 & & 1900 & 25.60 & 30,100 & \multirow[t]{3}{*}{ Aug. 5} & -0400 & 9.40 & 5,340 \\
\hline & 1400 & 6.60 & 2,320 & & 2000 & 28.00 & $37, \cap 00$ & & 1200 & 8.00 & 4,100 \\
\hline & 1600 & 8.25 & 3,590 & & 2200 & 32.60 & 58,100 & & 2400 & 6.90 & 3,240 \\
\hline & 1800 & 10.35 & 6,050 & & 2400 & 37.00 & 88,300 & & & & \\
\hline & 2000 & 17.70 & 14.400 & & & & & \multirow{2}{*}{ Aug. 6} & -1200 & 5.87 & 2,420 \\
\hline & 2200 & 25.30 & 27,600 & Aug. 4 & $=0100$ & 39.20 & 106,000 & & 2400 & 5.85 & 2,400 \\
\hline
\end{tabular}

\begin{tabular}{|c|c|c|c|}
\hline Period & \multicolumn{3}{|c|}{$\begin{array}{l}\text { Highest mean discharge, in cubic feet per second, } \\
\text { for the indicated number of consecutive days }\end{array}$} \\
\hline August 1978- & 76,500 & 43,200 & 20,100 \\
\hline 1923 to July 1978 & 66,100 & 32,700 & 14,900 \\
\hline
\end{tabular}

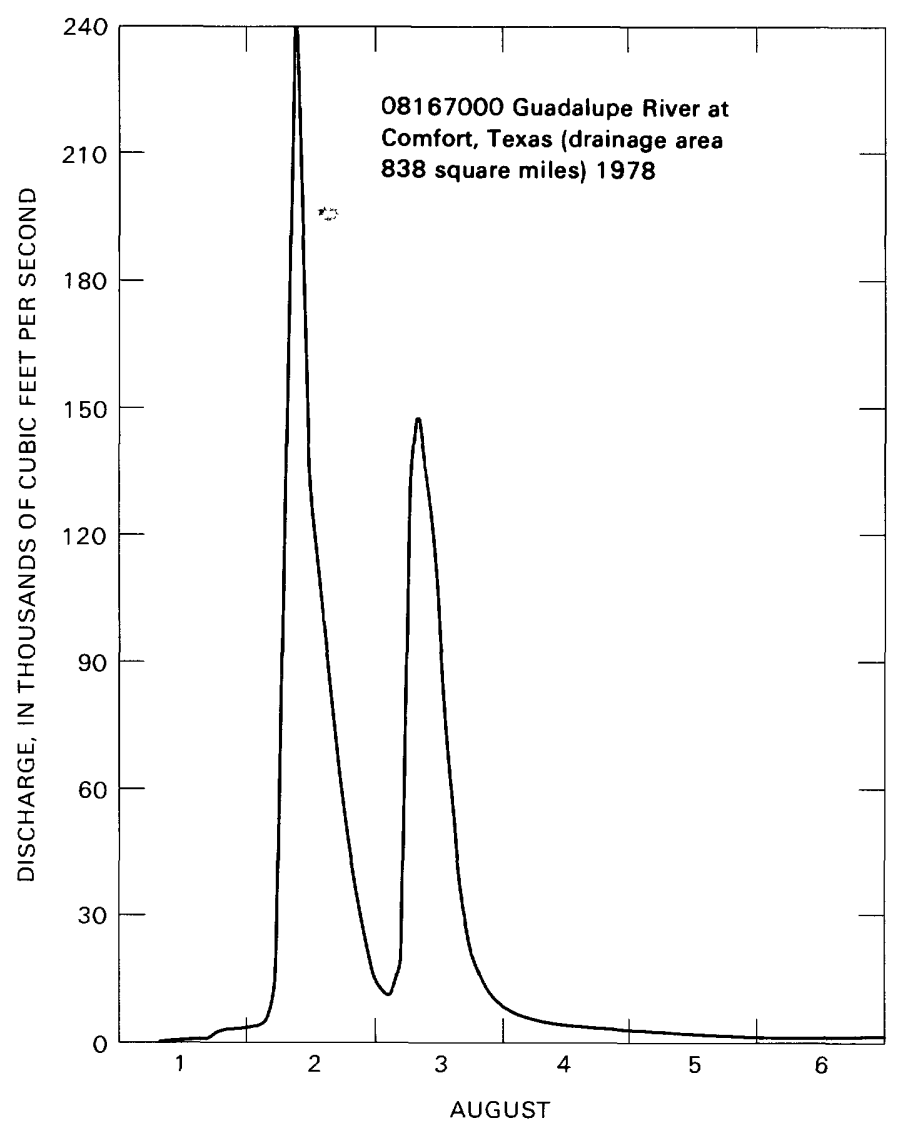

FIGURE 15.-Discharge hydrograph of Guadahupe River near Comfort for August 1-6, 1978.

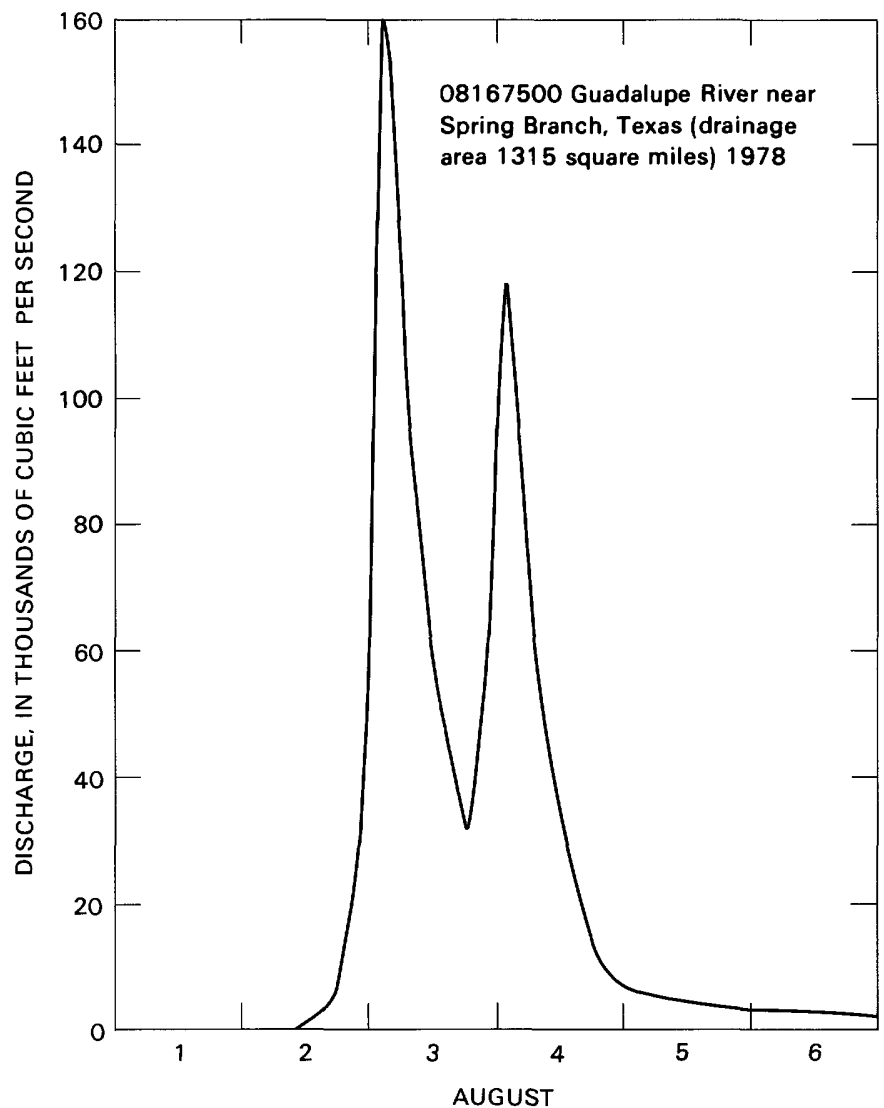

FIGURE 16.-Discharge hydrograph of Guadalupe River near Spring Branch for August 1-6, 1978. 
TABLE 8. - Data for gaging station 08179000 Medina River near Pipe Creek

[Gage height, in feet, and discharge, in cubic feet per second, at indicated time, 1978]

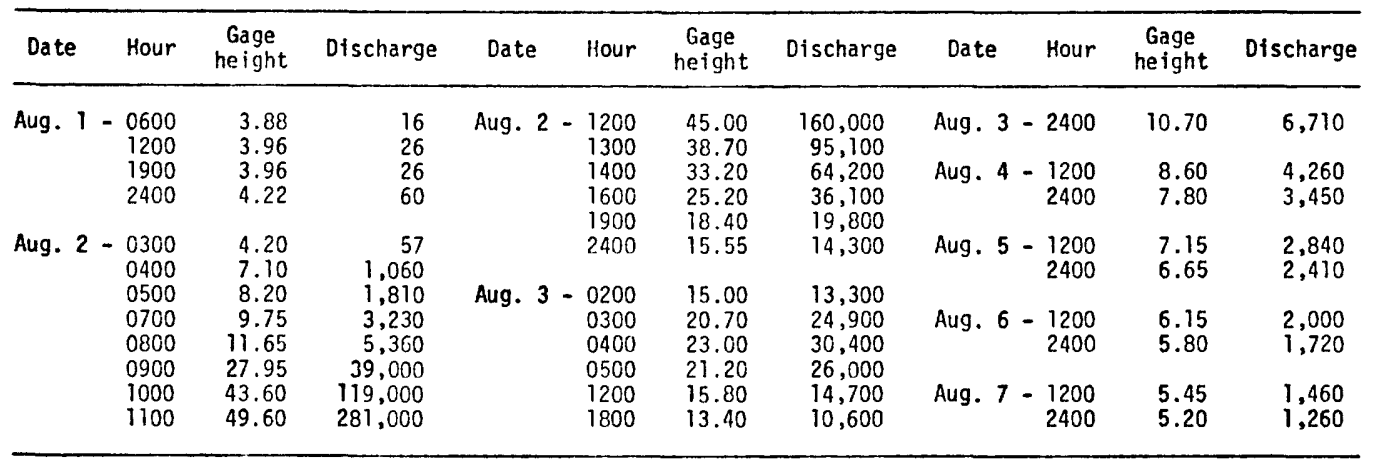

\begin{tabular}{|c|c|c|c|}
\hline Period & 1 & $\begin{array}{l}\text { ge, in cubic feet per second, } \\
\text { number of consecutive days } \\
3\end{array}$ & 7 \\
\hline August 1978- & 41,700 & 20,100 & 9,640 \\
\hline 1924 to July 1978 & 23,000 & 15,000 & 7,900 \\
\hline
\end{tabular}
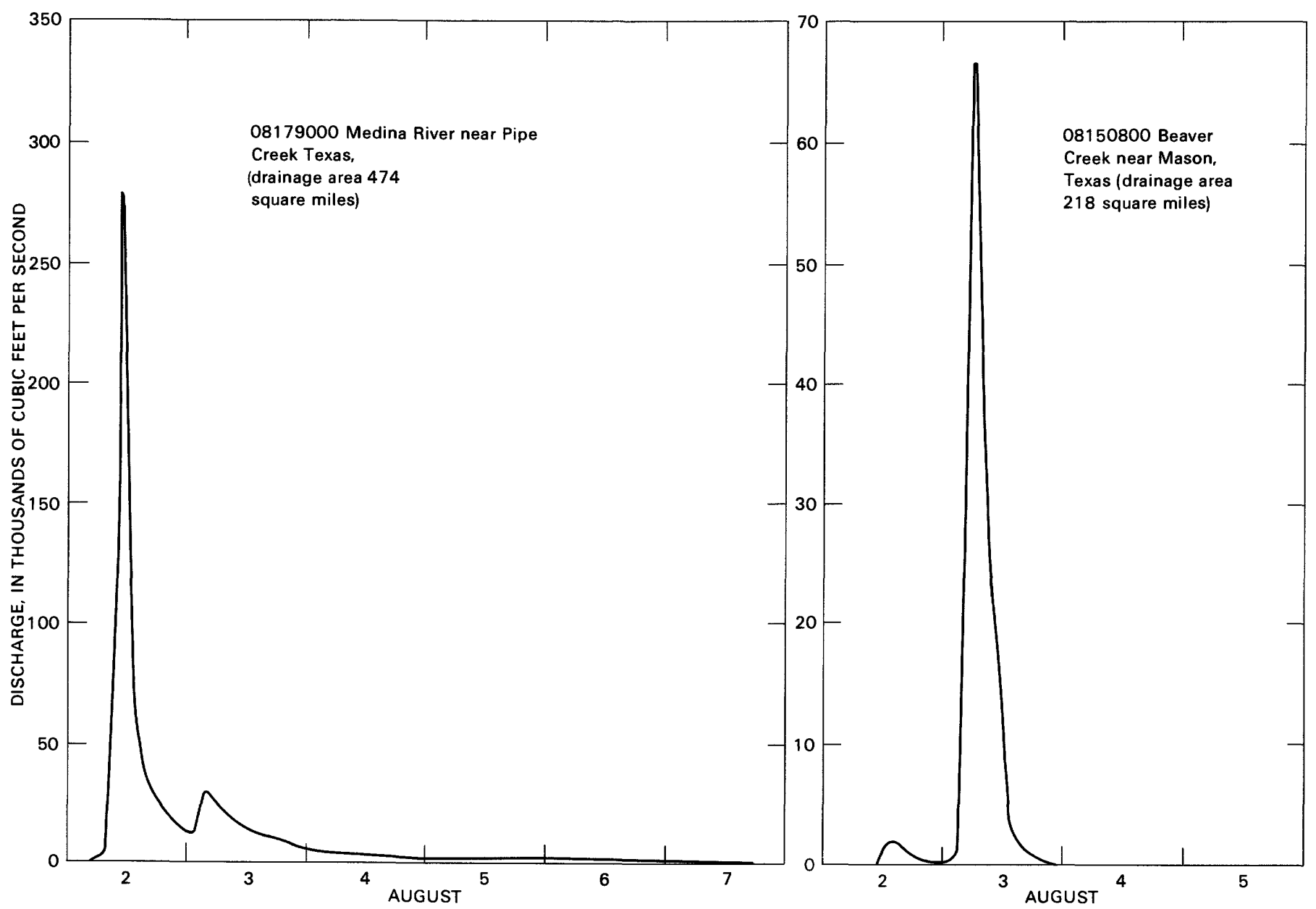

FIGURE 17.-Discharge hydrographs of Medina River near Pipe Creek for August 2-7, 1978, and Beaver Creek near Mason for August 2-5, 1978. 


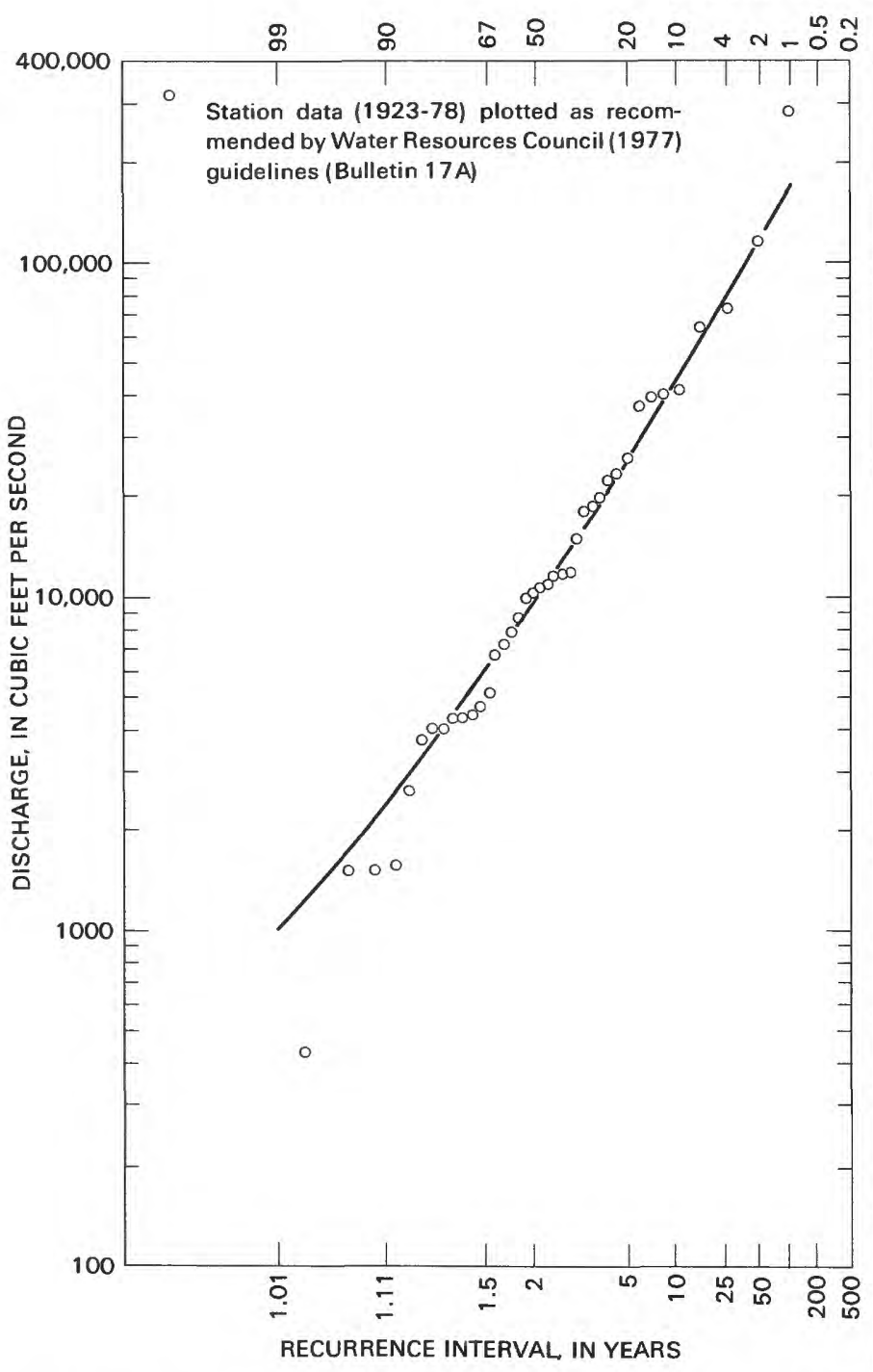

FIGURE 18. - Log-Pearson Type III frequency curve for Medina River near Pipe Creek.

The flood crest reached the stream-gaging station Medina River near Pipe Creek (site 82) on August 2, and exceeded by more than $6 \mathrm{ft}$ the previously known maximum stage since 1880, which occurred in 1919. The peak discharge was $281,000 \mathrm{ft}^{3} / \mathrm{s}$. A discharge hydropgraph for this station is shown in figure 17, and data are presented in table 8 . An analysis of the annual peak-flow data for this site shows that a discharge of $281,000 \mathrm{ft}^{3} / \mathrm{s}$ has a recurrence interval greatly in excess of 100 years (fig. 18). Red Bluff Creek (site 83), which flows into the Medina River just below the Pipe Creek gaging station, received very little runoff and had a peak discharge of only $160 \mathrm{ft}^{3} / \mathrm{s}$ on August 2 .

Medina Lake near San Antonio (site 84) reached a stage of $1,076.67 \mathrm{ft}$, with $4 \mathrm{ft}$ of flow over the spillway at the maximum stage. Storage in Medina Lake increased from 188,200 acreft at 0800 August 1 to 281,000 acre-ft at 1900 August 2.
One of the most striking indications of the severity of the flood was the destruction of massive cypress trees that lined the low-water banks of the Guadalupe and Medina Rivers and many of the tributaries. These trees ranged in size up to $6 \mathrm{ft}$ in diameter, and the larger trees were estimated to be as much as 600 years old (oral commun., David Riskin, Botanist, Texas Parks and Wildlife Department, September 1978). Entire stands of these picturesque trees were either uprooted or snapped off and floated downstream. Hundreds were left scattered along the flood plains (fig. 19) or lodged in huge piles of debris along the channel banks and beneath the highway bridges. Many of the trees that were not uprooted were left partially down and stripped of their bark and foliage (fig. 20).

In this area of central Texas, older trees develop an extensive system of large lateral roots because tap roots cannot penetrate the limestone bedrock beneath the shallow topsoil. When the receeding floodwaters became too shallow to maintain free flotation of the uprooted trees, the lateral roots carved distinctive ruts in the soil as the trees were moved along the flood plain. These straight narrow ruts defined the direction of flow.

\section{COLORADO RIVER BASIN}

\section{PEDERNALES RIVER}

Heavy rainfall was not as widespread in the Colorado River basin as in the Guadalupe and Medina River basins. The highest unit runoff observed during this storm occurred on Spring Creek, which is tributary to the Pedernales River. Spring Creek, a short distance upstream from the station Spring Creek near Fredericksburg (site 66), had a peak discharge of $42,500 \mathrm{ft}^{3} / \mathrm{s}$ from a $14.1-\mathrm{mi}^{2}$ drainage area. The

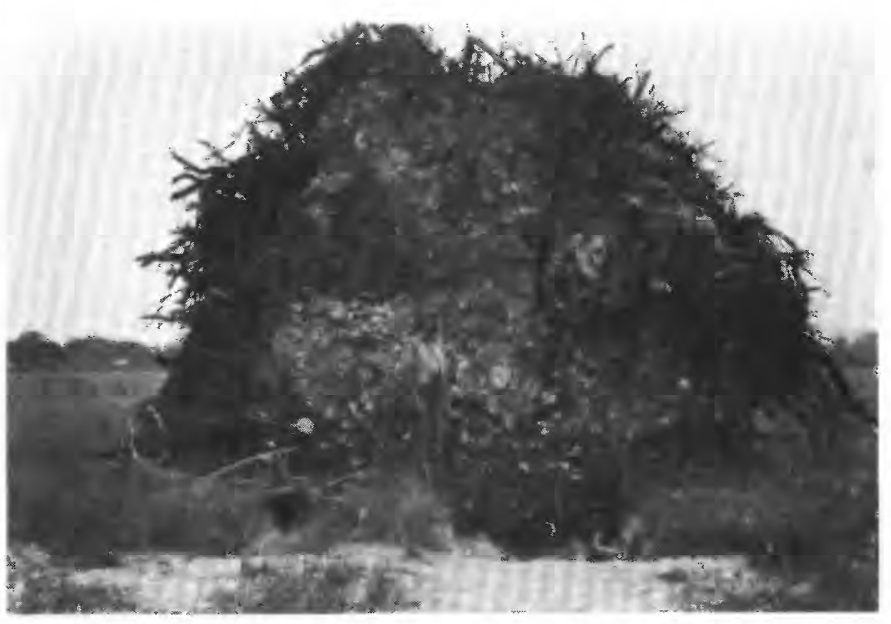

FIGURE 19. - Cypress tree uprooted by floodwaters on the Medina River. 

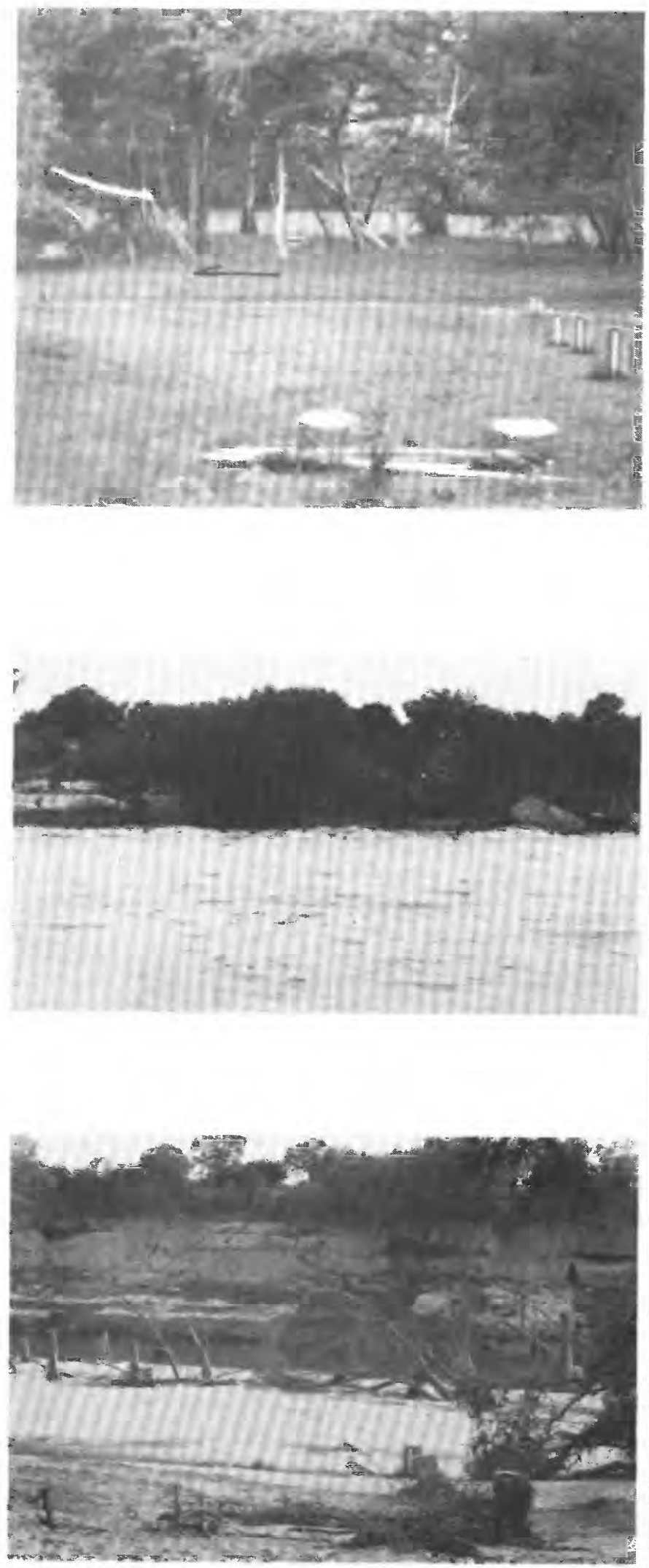

FIGURE 20.--Medina River near Pipe Creek, before, during, and after the flood. unit discharge was $3,010 \mathrm{ft}^{3} / \mathrm{s} / \mathrm{mi}^{2}$, which is equivalent to 4.67 in. of runoff per hour at the time of the peak. Overlank flooding occurred on the Pedernales River upstream from the gaging station near Johnson City (site 68), but the flood crest was $17.6 \mathrm{ft}$ lower than the crest of the September 1952 flood.

\section{LLANO RIVER}

Rainfall in the Llano River basin generally was 5 in. or less except in several small areas near Junction. The peak discharge on Bear Creek (site 59), which is tributary to the North Llano River just northwest of Junction, was 81,000 $\mathrm{ft}^{3} / \mathrm{s}$ from a drainage area of $155 \mathrm{mi}^{2}$. The floodwaters on Bear Creek inundated Interstate Highway 10, which was closed for several hours. At the gaging station on Beaver Creek near Mason (site 63), another tributary to the Llano River, the recorded peak stage of $24.00 \mathrm{ft}$ was over $10 \mathrm{ft}$ higher than the previous maximum in 1965, and the peak flow rate was $66,900 \mathrm{ft}^{3} / \mathrm{s}$. The discharge hydrograph for Beaver Creek near Mason is shown in figure 17, and data are presented in table 9 .

\section{BRAZOS RIVER BASIN}

On August 3, a new storm developed in the Brazos River basin. During the 24-hour period ending at 0700 August 4, a total of $29.05 \mathrm{in}$. of rain was recorded by the National Weather Service at Albany in Shackelford County. Record-breaking floods occurred on the Clear Fork Brazos River and on Hubbard Creek and other tributaries of the Clear Fork Brazos River. A peak discharge of $103,000 \mathrm{ft}^{3} / \mathrm{s}$ from a drainage area of $39.3 \mathrm{mi}^{2}$ was recorded at North Fork Hubbard Creek near Albany (site 18) on August 4. The unit discharge of $2,620 \mathrm{ft}^{3} / \mathrm{s} / \mathrm{mi}^{2}$ was one of the highest ever recorded in Texas for a drainage area of this size. The streamflow station Hubbard Creek below Albany (site 19) had a peak discharge of $330,000 \mathrm{ft}^{3} / \mathrm{s}$ from a drainage area of $613 \mathrm{mi}^{2}$. Discharge hydrographs for North Fork Hubbard Creek near Albany and Hubbard Creek below Albany are shown in figure 21, and data are presented in tables 10 and 11 , respectively.

The contents of Hubbard Creek Reservoir near Breckenridge (site 21) increased from 185,800 acre-ft at 2400 August 2 to a maximum of 401,500 acre-ft at 0800 August 5 . The reservoir effectively contained the floodwaters from the Hubbard Creek basin although it was not designed for flood control. Sufficient storage capacity was available in the reservoir to contain the flood wave with only moderate releases, which prevented more serious flooding downstream on the Clear Fork Brazos River. The streamflow station Hubbard Creek near Breckenridge (site 22), downstream from the reservoir and about $11 \mathrm{mi}$ upstream from the Clear Fork Brazos River, had a peak discharge of only $14,600 \mathrm{ft}^{3} / \mathrm{s}$. 
TABLE 9. - Data for gaging station 08150800 Beaver Creek near Mason

[Gage height, in feet, and discharge, in cubic feet per second, at indicated time, 1978]

\begin{tabular}{|c|c|c|c|c|c|c|c|c|c|c|c|}
\hline Date & Hour & $\begin{array}{c}\text { Gage } \\
\text { height }\end{array}$ & Discharge & Date & Hour & $\begin{array}{c}\text { Gage } \\
\text { height }\end{array}$ & Discharge & Date & Hour & $\begin{array}{l}\text { Gage } \\
\text { height }\end{array}$ & Discharge \\
\hline Aug. 2 - & $\begin{array}{l}0100 \\
0300 \\
0500 \\
0800 \\
1000 \\
1100 \\
1200 \\
1300 \\
1500 \\
1800 \\
2100\end{array}$ & $\begin{array}{l}1.85 \\
1.98 \\
2.10 \\
2.30 \\
2.72 \\
4.54 \\
5.54 \\
6.22 \\
6.07 \\
5.07 \\
4.23\end{array}$ & $\begin{array}{r}1.2 \\
3.8 \\
7.7 \\
18 \\
58 \\
590 \\
1,360 \\
2,310 \\
2,070 \\
912 \\
440\end{array}$ & $\begin{array}{l}\text { Aug. } 2 \text { - } \\
\text { Aug. } 3 \text { - }\end{array}$ & $\begin{array}{r}-2400 \\
-0200 \\
0300 \\
0400 \\
0500 \\
0600 \\
0700 \\
0900 \\
1100 \\
1200\end{array}$ & $\begin{array}{r}3.76 \\
3.82 \\
5.29 \\
13.37 \\
18.91 \\
24.00 \\
20.00 \\
13.90 \\
11.10 \\
9.00\end{array}$ & $\begin{array}{r}270 \\
281 \\
1,100 \\
23,500 \\
43,600 \\
66,900 \\
48,200 \\
25,200 \\
16,700 \\
10,900\end{array}$ & Aug. 3 . & $\begin{array}{r}1300 \\
1400 \\
1600 \\
1800 \\
2000 \\
2200 \\
2400 \\
-0200 \\
-0600 \\
1200 \\
2400\end{array}$ & $\begin{array}{l}5.97 \\
5.25 \\
4.35 \\
3.76 \\
3.35 \\
3.03 \\
2.77 \\
\\
2.56 \\
2.28 \\
2.00 \\
1.68\end{array}$ & $\begin{array}{r}4,060 \\
2,840 \\
1,420 \\
770 \\
470 \\
308 \\
211 \\
151 \\
93 \\
59 \\
40\end{array}$ \\
\hline
\end{tabular}

a

\begin{tabular}{|c|c|c|c|}
\hline Period & 1 & $\begin{array}{l}\text { e, in cubic feet per second, } \\
\text { umber of consecutive days } \\
3\end{array}$ & 7 \\
\hline August 1978- & 12,800 & 4,500 & 1,940 \\
\hline 1964 to July 1978 & 5,040 & 2,090 & 919 \\
\hline
\end{tabular}
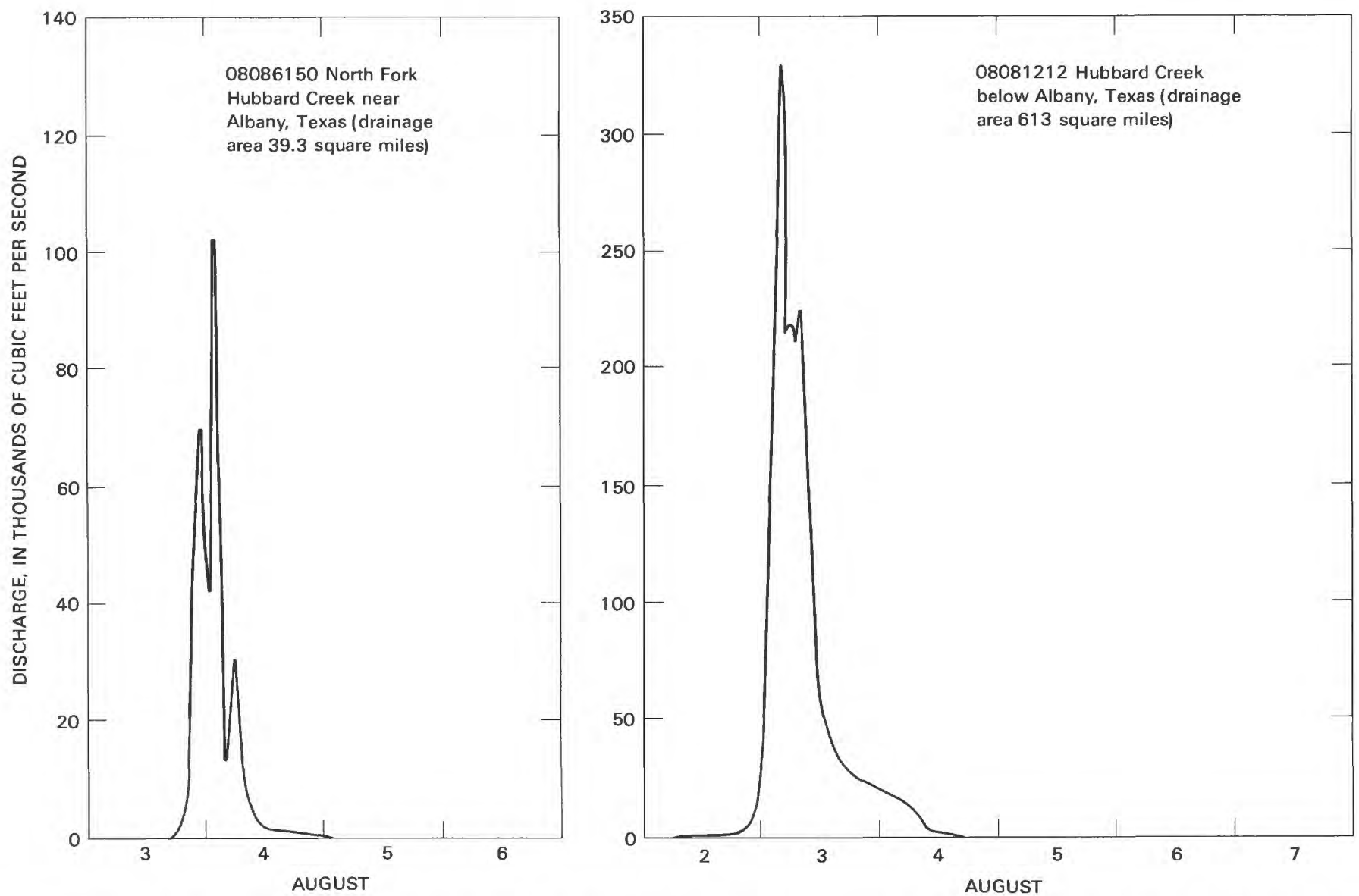

FIGURE 21. - Discharge hydrographs of North Fork Hubbard Creek near Albany for August 3-6, 1978, and Hubbard Creek below Albany for August 2-7, 1978. 
TABLE 10.-Data for gaging station 08086150 North Fork Hubbard Creek near Albany

[Gage height, in feet, and discharge, in cubic feet per second, at indicated time, 1978]

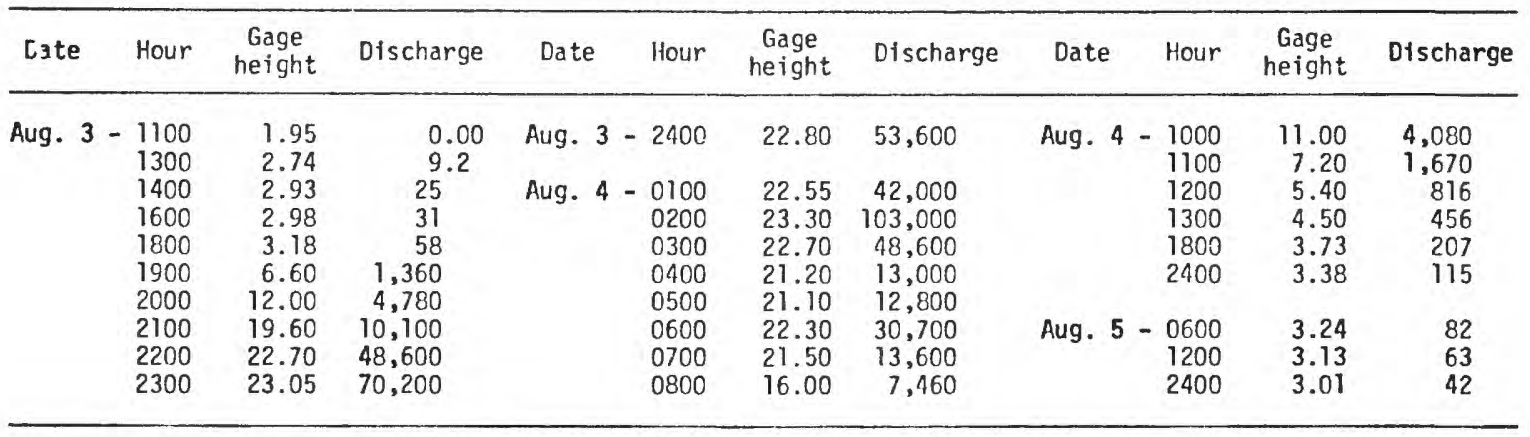

\begin{tabular}{|c|c|c|c|}
\hline Feriod & 1 & $\begin{array}{l}\text { e, in cubic feet per second, } \\
\text { umber of consecutive days } \\
3\end{array}$ & 7 \\
\hline August 1978--_on & 13,100 & 6,640 & 2,860 \\
\hline 1964 to July 1978 & 1,570 & 754 & 361 \\
\hline
\end{tabular}

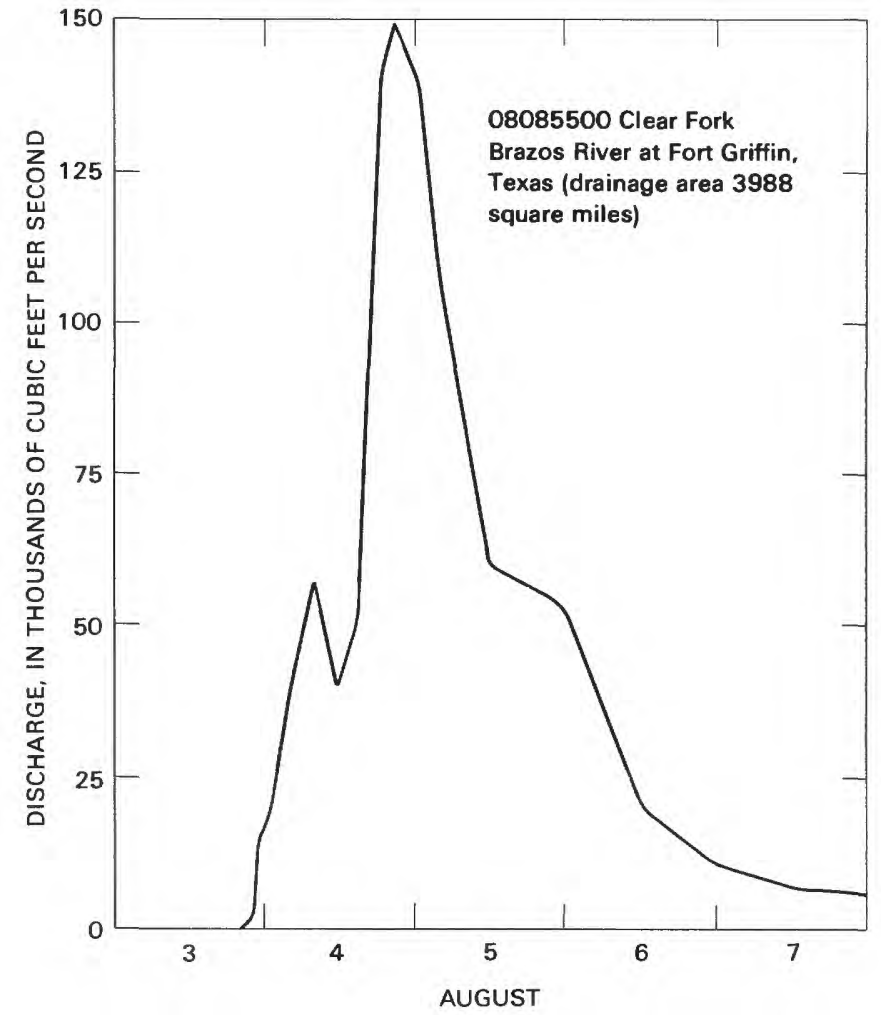

FIGURE 22.-Discharge hydrograph of Clear Fork Brazos River at Fort Griffin for August 3-7, 1978

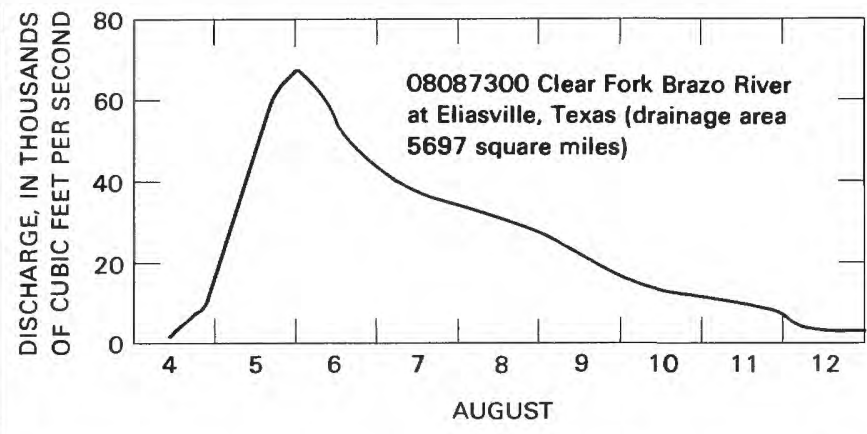

FIGURE 23. - Discharge hydrograph of Clear Fork Brazos River at Eliasville for August 4-12, 1978.

Serious flooding developed on the Clear Fork Brazos River as a result of heavy runoff from tributaries upstream from Hubbard Creek. California Creek near Stamford (site 14), which has a drainage area of $478 \mathrm{mi}^{2}$, had a peak discharge of $40,000 \mathrm{ft}^{3} / \mathrm{s}$. The gaging station on the Clear Fork Brazos River at Fork Griffin (site 16) recorded a peak discharge of $149,000 \mathrm{ft}^{3} / \mathrm{s}$, and the stage exceeded the previously known maximum stage by $0.88 \mathrm{ft}$. When the flood crest reached the gaging station at Eliasville (site 23), $13.2 \mathrm{mi}$ upstream from the main stem of the Brazos River, the peak discharge had attentuated to $68,000 \mathrm{ft}^{3} / \mathrm{s}$. A discharge hydrograph for Clear Fork Brazos River at Fort Griffin is shown in figure 22, and data are presented in table 12. A discharge hydrograph for Clear Fork Brazos River at Eliasville is shown in figure 23, and data are presented in table 13. 
BRAZOS RIVER BASIN

TABLE 11. - Data for gaging station 08086212 Hubbard Creek below Albany

[Gage height, in feet, and discharge, in cubic feet per second, at indicated time, 1978]

\begin{tabular}{|c|c|c|c|c|c|c|c|c|c|c|c|}
\hline Date & Hour & $\begin{array}{c}\text { Gage } \\
\text { height }\end{array}$ & Discharge & Date & Hour & $\begin{array}{c}\text { Gage } \\
\text { height }\end{array}$ & Discharge & Date & Hour & $\begin{array}{c}\text { Gage } \\
\text { height }\end{array}$ & Discharge \\
\hline Aug. 3 & $\begin{array}{l}0400 \\
0600 \\
1200 \\
1300 \\
1500 \\
1800 \\
2100 \\
2200 \\
2300 \\
2400\end{array}$ & $\begin{array}{r}3.31 \\
3.81 \\
4.04 \\
7.37 \\
8.13 \\
9.74 \\
12.72 \\
18.01 \\
23.88 \\
30.17\end{array}$ & $\begin{array}{c}0.00 \\
3.8 \\
6.9 \\
681 \\
1,020 \\
1,980 \\
3,760 \\
7,890 \\
15,300 \\
26,300\end{array}$ & \multirow[t]{2}{*}{ Aug. 4 - } & $\begin{array}{l}0300 \\
0400 \\
0430 \\
0500 \\
0600 \\
0700 \\
0730 \\
0800 \\
1000 \\
1200 \\
1500\end{array}$ & $\begin{array}{l}39.89 \\
41.41 \\
41.15 \\
40.29 \\
40.33 \\
40.19 \\
40.39 \\
10.01 \\
38.11 \\
35.72\end{array}$ & \multirow[t]{2}{*}{$\begin{array}{r}189,000 \\
330,000 \\
300,000 \\
218,000 \\
221,000 \\
210,000 \\
226,000 \\
196,000 \\
112,000 \\
56,000 \\
33,700 \\
25,900 \\
21,600\end{array}$} & \multicolumn{2}{|c|}{$\begin{array}{r}\text { Aug. } 5 \text { - } 0600 \\
0800 \\
1000 \\
1200 \\
1800 \\
2400\end{array}$} & $\begin{array}{r}23.30 \\
18.00 \\
11.40 \\
9.40 \\
7.80 \\
7.19\end{array}$ & $\begin{array}{r}14,400 \\
7,920 \\
2,970 \\
1,840 \\
942 \\
657 \\
\\
391 \\
250\end{array}$ \\
\hline Aug. 4 & $\begin{array}{l}0100 \\
0200\end{array}$ & $\begin{array}{l}35.79 \\
38.29\end{array}$ & $\begin{array}{r}56,700 \\
118,000\end{array}$ & & $\begin{array}{l}1500 \\
1800 \\
2400\end{array}$ & $\begin{array}{l}32.44 \\
29.94 \\
27.67\end{array}$ & & \multicolumn{2}{|c|}{ Aug. $7-\begin{array}{r}1200 \\
2400\end{array}$} & $\begin{array}{l}5.65 \\
5.40\end{array}$ & $\begin{array}{l}164 \\
122\end{array}$ \\
\hline
\end{tabular}

\begin{tabular}{|c|c|c|c|}
\hline Period & & $\begin{array}{l}\text { ge, in cubic feet per second, } \\
\text { number of consecutive days } \\
3\end{array}$ & 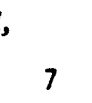 \\
\hline August 1978 & 94,700 & 34,400 & 14,800 \\
\hline 1967 to July 1978 & 20,100 & 14,600 & 6,670 \\
\hline
\end{tabular}

TABLE 12. - Data for gaging station 08085500 Clear Fork Brazos River at Fort Griffin

[Gage height, in feet, and discharge, in cubic feet per second, at indicated time, 1978]

\begin{tabular}{|c|c|c|c|c|c|c|c|c|c|c|c|}
\hline Date & Hour & $\begin{array}{c}\text { Gage } \\
\text { height }\end{array}$ & Discharge & Date & Hour & $\begin{array}{c}\text { Gage } \\
\text { height }\end{array}$ & Discharge & Date & Hour & $\begin{array}{c}\text { Gage } \\
\text { height }\end{array}$ & Discharge \\
\hline \multicolumn{2}{|c|}{$\begin{array}{r}\text { Aug. } 3-2100 \\
2200 \\
2300 \\
2400\end{array}$} & $\begin{array}{r}1.54 \\
6.28 \\
19.20 \\
25.20\end{array}$ & $\begin{array}{r}0 \\
1,360 \\
13,900 \\
16,900\end{array}$ & \multicolumn{2}{|c|}{$\begin{array}{r}\text { Aug. } 4-1700 \\
1900 \\
2100 \\
2400\end{array}$} & $\begin{array}{l}38.10 \\
38.81 \\
38.88 \\
38.76\end{array}$ & $\begin{array}{l}108,000 \\
142,000 \\
149,000 \\
141,000\end{array}$ & \multicolumn{2}{|c|}{$\begin{array}{r}\text { Aug. } 6-2400 \\
\text { Aug. } 7-\begin{array}{r}1200 \\
2400\end{array}\end{array}$} & $\begin{array}{l}21.55 \\
16.15\end{array}$ & $\begin{array}{r}10,400 \\
7,340 \\
5,160\end{array}$ \\
\hline \multirow{2}{*}{\multicolumn{2}{|c|}{ 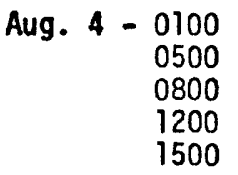 }} & \multirow{2}{*}{$\begin{array}{l}28.81 \\
35.66 \\
36.56 \\
35.58 \\
36.32\end{array}$} & \multirow{2}{*}{$\begin{array}{l}20,800 \\
43,200 \\
57,000 \\
39,500 \\
52,000\end{array}$} & \multirow{2}{*}{\multicolumn{2}{|c|}{$\begin{array}{r}\text { Aug. } 5-0400 \\
1200 \\
2400\end{array}$}} & $\begin{array}{l}38.18 \\
36.75 \\
34.40\end{array}$ & $\begin{array}{r}107,000 \\
59,600 \\
28,600\end{array}$ & Aug. 8 & $\begin{array}{r}-1200 \\
2400\end{array}$ & $\begin{array}{l}13.17 \\
11.48\end{array}$ & $\begin{array}{l}4,040 \\
3,360\end{array}$ \\
\hline & & & & & & 32.80 & 20,800 & Aug. 9 & $\begin{array}{r}-1200 \\
2400\end{array}$ & $\begin{array}{r}10.18 \\
9.19\end{array}$ & $\begin{array}{l}2,850 \\
2,500\end{array}$ \\
\hline
\end{tabular}

Period

Highest mean discharge, in cubic feet per second, for the indicated number of consecutive days

$1 \quad 3 \quad 7$

\begin{tabular}{llll}
\hline August 1978 & 72,800 & 53,500 & 25,400 \\
1925 to July 1978 & 30,800 & 24,000 & 15,300 \\
\hline
\end{tabular}


TABLE 13.-Data for gaging station 08087300 Clear Fork Brazos River at Eliasville

[Gage height, in feet, and discharge, in cubic feet per second, at indicated time, 1978]

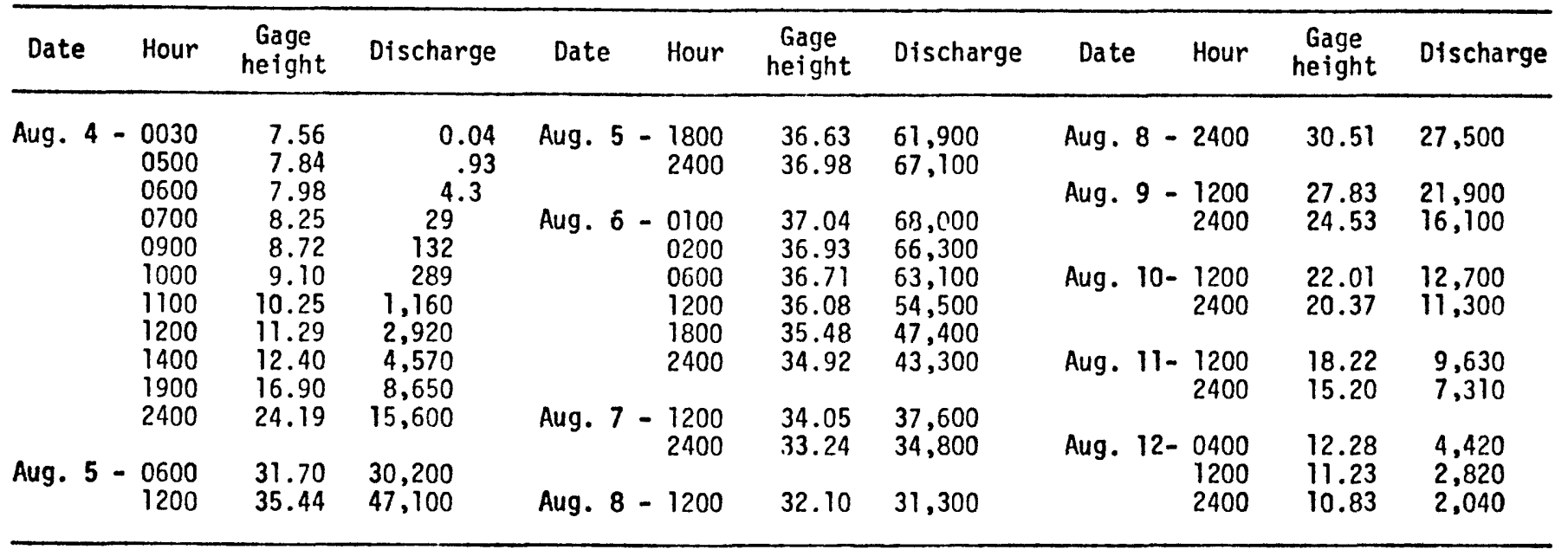

\begin{tabular}{|c|c|c|c|}
\hline Period & 1 & $\begin{array}{l}\text { ge, in cubic feet per second, } \\
\text { number of consecutive days } \\
3\end{array}$ & 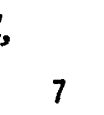 \\
\hline August 1978 & 55,200 & 46,400 & 30,700 \\
\hline 1917 to July 1978 & 32,400 & 23,200 & 16,600 \\
\hline
\end{tabular}

Some tributaries to the Brazos River upstream from the Clear Fork Brazos River also experienced high rates of runoff. Millers Creek near Munday (site 2), which has a drainage area of $104 \mathrm{mi}^{2}$, had a peak discharge of $34,600 \mathrm{ft}^{3} / \mathrm{s}$. Discharge hydrographs for Millers Creek near Munday and California Creek near Stamford are shown in figure 24, and data are presented in tables 14 and 15 , respectively.

The streamflow gaging station on the Brazos River near South Bend (site 24), $1.8 \mathrm{mi}$ downstream from the Clear Fork Brazos River, has a peak discharge of $78,100 \mathrm{ft}^{3} / \mathrm{s}$. Although this discharge was exceeded by a flood that occurred in May 1941, the peak stage ( $41.5 \mathrm{ft}$ ) was the greatest to occur since at least 1876 . Because of changes in the stage-discharge relationship, the peak stage of the August 1978 flood exceeded that of May 1941 by about $14 \mathrm{ft}$.

Major flooding occurred along the Brazos River from South Bend to Possum Kingdom Reservoir. Possum Kingdom Reservoir was $6.6 \mathrm{ft}$ below the normal pool level before the heavy runoff began. Releases from the reservoir by the Brazos River Authority, in anticipation of the approaching flood wave, reduced the crest of the flood and effectively prevented a more serious flood from occurring downstream.
Flood damages in the Brazos River basin downstream from Possum Kingdom Reservoir were minimal. Flooding did not occur on the Brazos River downstream from Lake Whitney, where sufficient storage capacity was available to contain the floodwaters.

\section{MAGNITUDE AND FREQUENCY OF THE FLOODS}

The relationship of flood-peak magnitude to the probability of occurrence, or recurrence interval, generally is referred to as a flood-frequency relation. The probability of occurrence is the percent chance of a given flood magnitude being exceeded in any 1 year. The recurrence interval, which is the reciprocal of the probability of occurrence multiplied by 100 , is the average number of years between exceedances. It is emphasized that the recurrence interval is an average interval and that the occurrence of floods is assumed to be random in time; no schedule of regularity is implied. The occurrence of a flood having a 50-year recurrence interval (2-percent chance of occurrence) is no guarantee, therefore, that a flood of equal or greater magnitude will not occur the following year, or even the following week. 
TABLE 14. - Data for gaging station 08082700 Millers Creek near Munday

[Gage height, in feet, and discharge, in cubic feet per second, at indicated time, 1978]

\begin{tabular}{|c|c|c|c|c|c|c|c|c|c|c|c|}
\hline Date & Hour & $\begin{array}{c}\text { Gage } \\
\text { height }\end{array}$ & Discharge & Date & Hour & $\begin{array}{c}\text { Gage } \\
\text { height }\end{array}$ & Discharge & Date & Hour & $\begin{array}{c}\text { Gage } \\
\text { height }\end{array}$ & Discharge \\
\hline Aug. 4 - & $\begin{array}{l}0300 \\
0400 \\
0500 \\
0600 \\
0800 \\
0900 \\
1000\end{array}$ & $\begin{array}{l}0.52 \\
.52 \\
1.01 \\
2.76 \\
3.96 \\
5.84 \\
8.45\end{array}$ & $\begin{array}{c}0 \\
1.0 \\
2.0 \\
32 \\
82 \\
216 \\
372\end{array}$ & Aug. 4 & $\begin{array}{r}-1400 \\
1500 \\
1600 \\
1800 \\
2200 \\
2400\end{array}$ & $\begin{array}{l}17.53 \\
17.34 \\
17.05 \\
16.32 \\
15.58 \\
15.40\end{array}$ & $\begin{array}{r}34,600 \\
30,600 \\
25,400 \\
15,600 \\
8,910 \\
7,690\end{array}$ & $\begin{array}{l}\text { Aug. } 5 \\
\text { Aug. } 6\end{array}$ & $\begin{array}{r}-2400 \\
-\quad 0600 \\
1200 \\
1800 \\
2400\end{array}$ & $\begin{array}{r}12.63 \\
11.27 \\
8.35 \\
4.49 \\
3.08\end{array}$ & $\begin{array}{r}790 \\
589 \\
366 \\
114 \\
42\end{array}$ \\
\hline & $\begin{array}{l}1100 \\
1200 \\
1300\end{array}$ & $\begin{array}{l}10.94 \\
13.86 \\
17.07\end{array}$ & $\begin{array}{r}555 \\
2,080 \\
25,700\end{array}$ & Aug. 5 & $\begin{array}{r}-0600 \\
1200 \\
1800\end{array}$ & $\begin{array}{l}14.95 \\
14.18 \\
13.52\end{array}$ & $\begin{array}{l}5,280 \\
2,750 \\
1,530\end{array}$ & Aug. 7 & $\begin{array}{r}-0600 \\
1800 \\
2400\end{array}$ & $\begin{array}{l}2.53 \\
1.99 \\
1.78\end{array}$ & $\begin{array}{c}25 \\
13 \\
9.9\end{array}$ \\
\hline
\end{tabular}

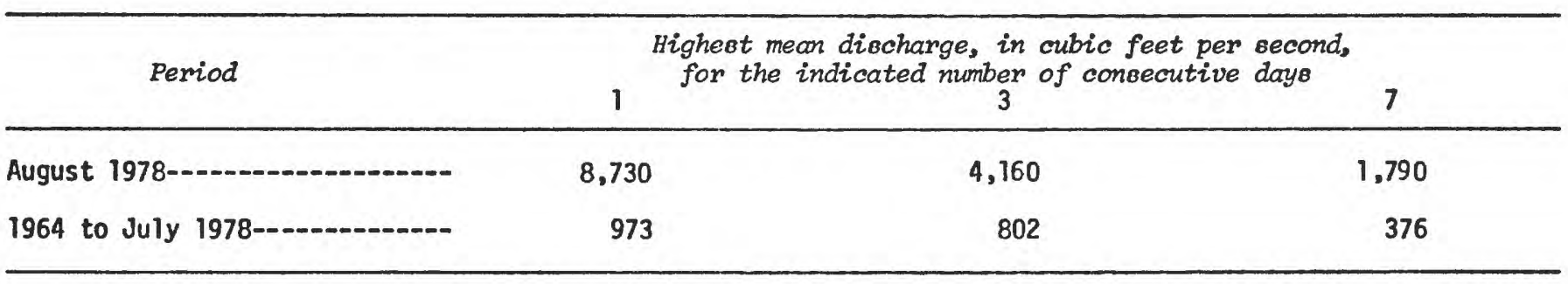

TABLE 15. - Data for gaging station 08084800 California Creek near Stamford [Gage height, in feet, and discharge, in cubic feet per second, at indicated time, 1978]

\begin{tabular}{|c|c|c|c|c|c|c|c|c|c|c|c|}
\hline Date & Hour & $\begin{array}{c}\text { Gage } \\
\text { height }\end{array}$ & Discharge & Date & Hour & $\begin{array}{c}\text { Gage } \\
\text { height }\end{array}$ & Discharge & Date & Hour & $\begin{array}{c}\text { Gage } \\
\text { height }\end{array}$ & Discharge \\
\hline Aug. 3 - & $\begin{array}{r}-1000 \\
1100 \\
1200 \\
1400 \\
1600 \\
1800 \\
2000 \\
2200 \\
2400\end{array}$ & $\begin{array}{r}6.38 \\
6.67 \\
7.38 \\
8.40 \\
10.33 \\
13.14 \\
16.31 \\
24.38 \\
27.90\end{array}$ & $\begin{array}{c}0.44 \\
6.3 \\
44 \\
107 \\
270 \\
600 \\
1,190 \\
4,260 \\
9,670\end{array}$ & Aug. $4-$ & $\begin{array}{l}0200 \\
0400 \\
0600 \\
0700 \\
0800 \\
1200 \\
1500 \\
2000 \\
2400\end{array}$ & $\begin{array}{l}29.25 \\
30.20 \\
30.94 \\
31.00 \\
30.92 \\
30.07 \\
29.34 \\
28.14 \\
27.17\end{array}$ & $\begin{array}{r}15,700 \\
24,800 \\
38,600 \\
40,000 \\
38,200 \\
23,000 \\
16,400 \\
10,500 \\
7,550\end{array}$ & $\begin{array}{l}\text { Aug. } 5 \text { - } \\
\text { Aug. } 6 \text { - }\end{array}$ & $\begin{array}{l}0600 \\
0900 \\
1200 \\
1500 \\
2000 \\
2400 \\
0400 \\
0800 \\
1200 \\
2400\end{array}$ & $\begin{array}{r}24.82 \\
21.00 \\
15.20 \\
12.25 \\
10.13 \\
9.38 \\
8.37 \\
7.73 \\
7.33 \\
7.30\end{array}$ & $\begin{array}{r}4,640 \\
2,500 \\
941 \\
485 \\
251 \\
185 \\
\\
105 \\
64 \\
40 \\
38\end{array}$ \\
\hline
\end{tabular}

\begin{tabular}{|c|c|c|c|}
\hline Period & \multicolumn{3}{|c|}{ Highest mean discharge, in cubic feet per second, } \\
\hline August 1978- & 20,400 & 7,860 & 3,380 \\
\hline 1963 to July 1978 & 5,820 & 4,950 & 3,040 \\
\hline
\end{tabular}



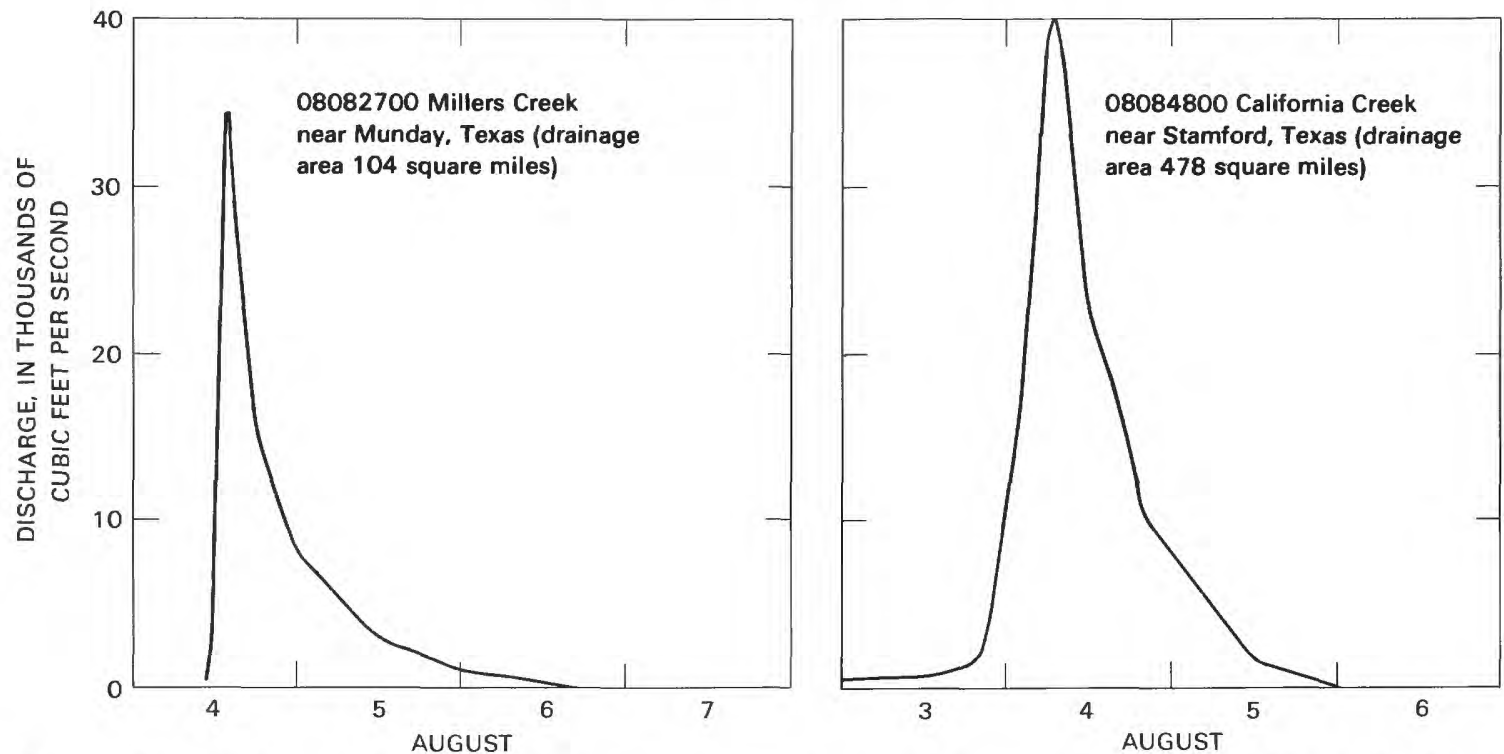

FIGURE 24.-Discharge hydrographs of Millers Crcek near Munday for August 4-7, 1978, and California Creek near Stamford for August 3-6, 1978.

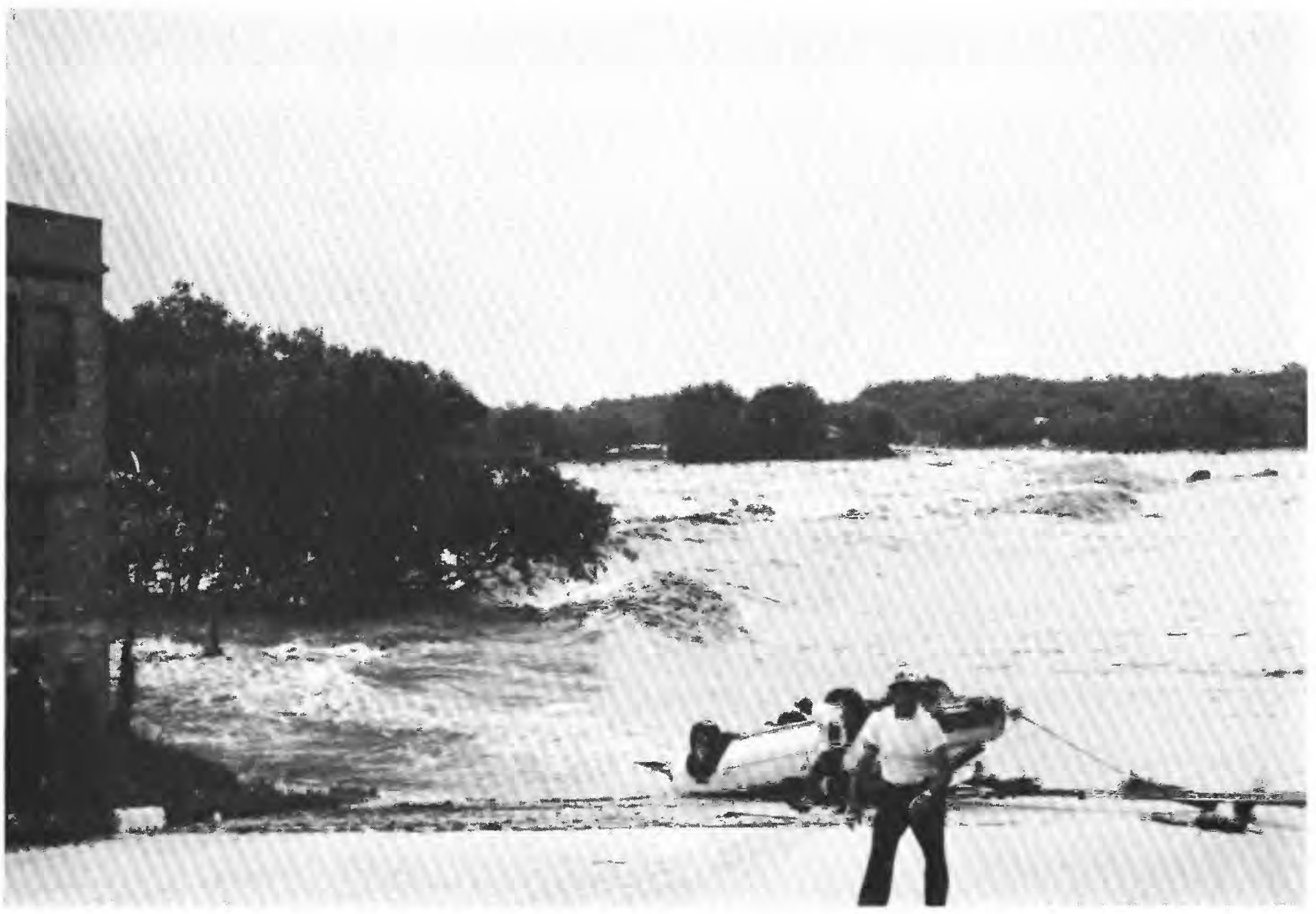

FIGURE 25. - Inundation of State Highway 173 and the Medina River bridge at Bandera. 


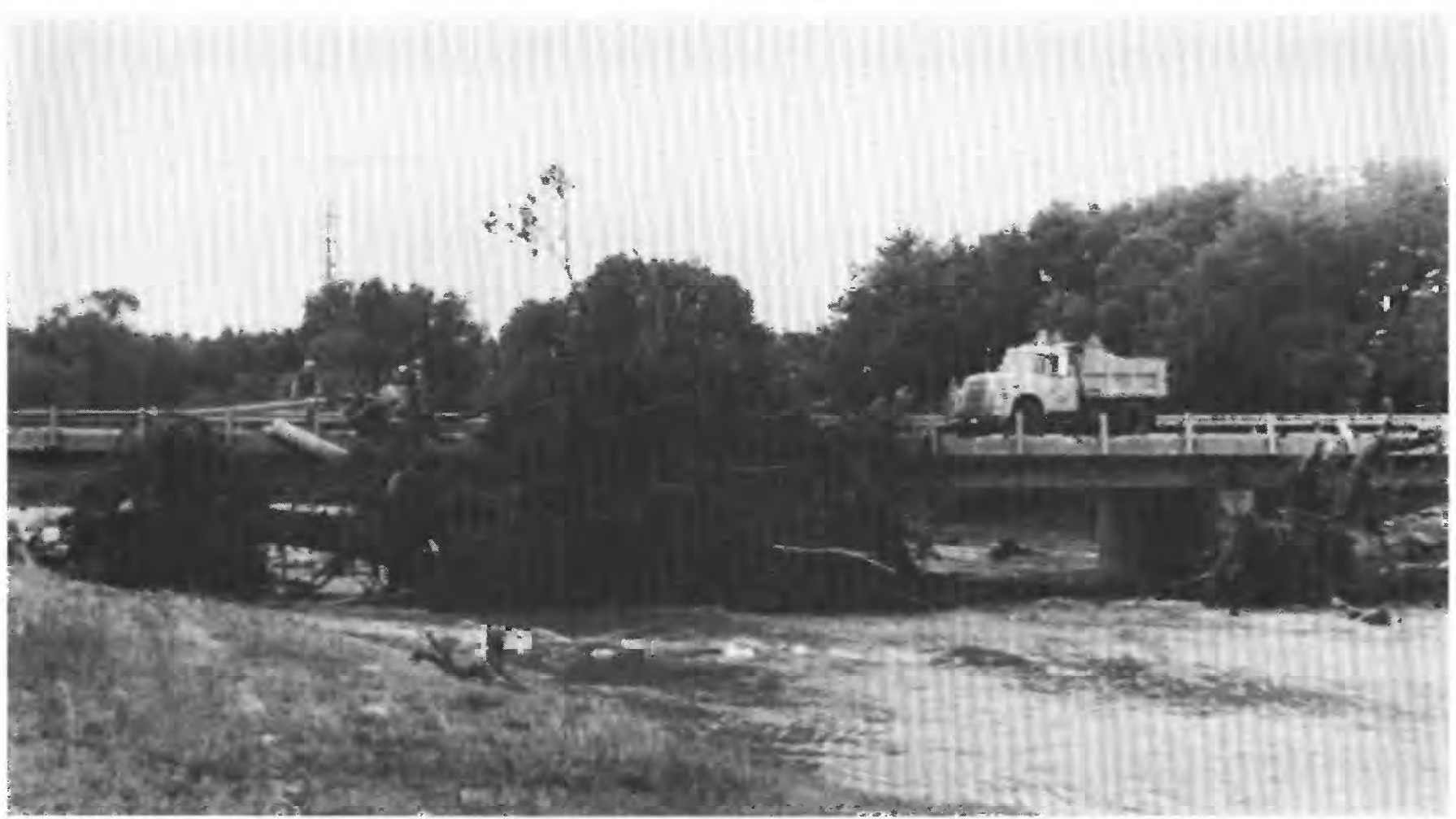

FIGURE 26. - State Highway 290 flooded by Spring Creek near Fredericksburg.

Recurrence intervals of peak discharges on the Clear Fork Brazos River, Guadalupe River above Canyon Lake, and Medina River above Medina Lake were greater than 100 years. The peak discharge for Spring Creek near Fredericksburg (site 66) was 3.8 times the magnitude of the 100-year regional flood. Flood-frequency data are presented in table 4 for all stations in the flood area that experienced floods with frequencies of 10 years of more.

\section{FLOOD DAMAGE}

Seventeen counties in central Texas sustained widespread damages from the floods associated with tropical storm Amelia (National Oceanic and Atmospheric Administration, 1978). Eight of these counties (Bandera, Kendall, and Kerr Counties in south-central Texas, and Haskell, Shackelford, Stephens, Throckmorton, and Young Counties in northcentral Texas) were declared flood-disaster areas by the Federal government. Ironically, Bandera, Kendall, and Kerr Counties had been declared drought-disaster areas prior to the floods.

In Bandera, Kendall, and Kerr Counties, 25 people were drowned, about 150 people were injured, and property damages were estimated to be at least 50 million dollars. About 175 homes were destroyed or damaged. Public utilities were disrupted in much of the area and many roadways and bridges were heavily damaged. The bridge on State Highway 173 over the Medina River at Bandera, which was designed to withstand the 50-year flood, was inundated by $18 \mathrm{ft}$ of water (fig. 25). The damage to livestock and crops, to farm and ranch facilities, and to farm and pasture lands was extremely heavy.

Much damage was sustained in Gillespie and Kimble Counties in south-central Texas. Two people were drowned when Spring Creek inundated the bridge on State Highway 290 west of Fredericksburg (fig. 26). Many roadways, bridges, and farm and ranch lands were extensively damaged.

In Haskell, Shackelford, Stephens, Throckmorton, and Young Counties in the Brazos River basin in north-central Texas, the flood damage was comparable to the damage in south-central Texas. Six people were drowned, four were injured, and property damages were estimated to be at least $\$ 62$ million. About 750 homes and 75 businesses were destroyed or damaged (fig. 27), and the damages to livestock, crops, and farm and ranch lands were extremely severe. In Haskell County alone, these damages were estimated to be about $\$ 30$ million.

In the total area affected by the storm, 33 people were drowned and 154 were injured. Property damages were estimated to be more than $\$ 110$ million. 


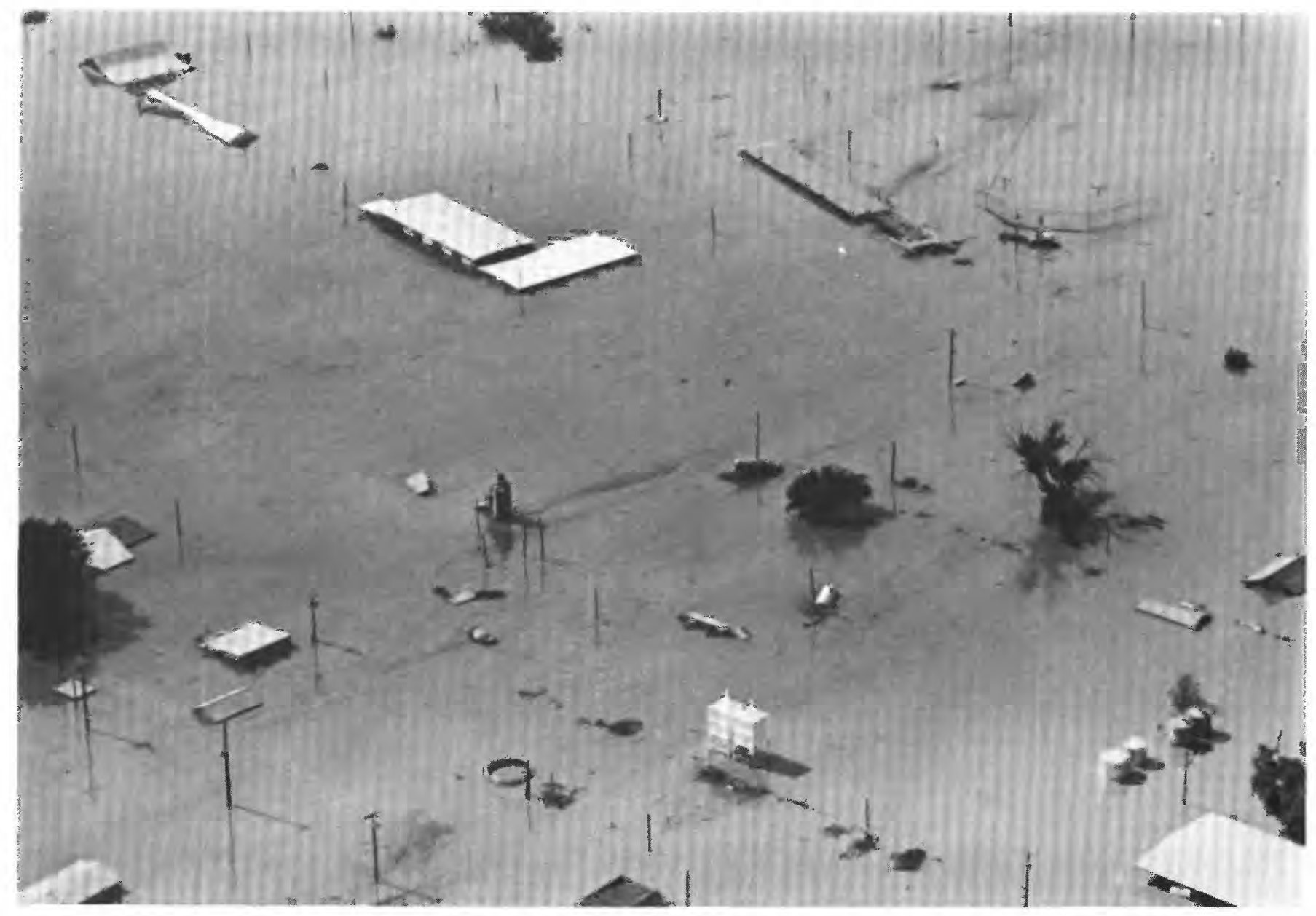

FIGURE 27. - Aerial view of the Brazos River in flood at Graham.

\section{SUMMARY}

The catastrophic floods in central Texas during August $1-4,1978$, were the result of two separate major storms of different origin and distinguishable time and geographical context but with some shared features. The presence of very moist maritime air that originated in the Gulf of Mexico and the presence of positive vorticity advection preceded the outbreak of both storms. In the case of the storm of August 1-3 over the hill country of south-central Texas, moist Gulf air initially was brought into the area by the cyclonic circulation of the remnant of tropical storm Amelia. The storm of August 3-4 over the upper Brazos River basin in north-central Texas resulted from the interaction of a cold front with the maritime air mass that penetrated deeply into north-central Texas.
Major flooding of the hill country in south-central Texas occurred on the Medina River and its tributaries above the Medina Lake and on the Guadalupe River and its tributaries above Canyon Lake. Moderate to severe flooding occurred on tributaries of the Nueces River, on Clear Fork Brazos River and its tributaries, and on the Llano and Pedernales Rivers, which are tributaries of the Colorado River. Peak discharges at several streamflow stations exceeded the historic peaks. The highest unit discharge observed was $3,010 \mathrm{ft}^{3} / \mathrm{s} / \mathrm{mi}^{2}$ from the 14.1- $\mathrm{mi}^{2}$ drainage area of Spring Creek, which is a tributary of the Perdanales River. In the upper Brazos River basin in north-central Texas, $6 \mathrm{ft}$ of water inundated the town of Albany on a tributary of Clear Fork Brazos River. Floodwater opened gaps in the earthen dam of Albany Reservoir and overtopped the spillway at Lake Throckmorton. Thirty-three lives were lost and total damages reportedly exceeded $\$ 110$ million. 


\section{SELECTED REFERENCES}

Ellsworth, C.E., 1923, The floods in central Texas in September 1921: U.S. Geological Survey Water-Supply Paper 488, 56p.

Environmental Science Services Administration, 1968, Climatic atlas of the United States: U.S. Department of Commerce, Environmental Science Services Administration, Environmental Data Service, 262 p.

Hershfield, D.M., 1961, Rainfall frequency atlas of the United States for durations from 30 minutes to 24 hours and return periods from 1 to 100 years: U.S. Weather Bureau Technical Paper No. 40, 115 p.

Ho, F.P., and Riedel, J.T., 1979, Precipitable water over the United States, Volume II, Semimonthly maxima: U.S. Department of Commerce, National Oceanic and Atmospheric Administration, National Weather Service, NOAA Technical Report NWS 20, 359 p.

Klazura, G.E., 1971. Measurements of precipitation particles in warm cumuli over southeast Texas: Journal of Applied Meteorology 10, p. $739-750$

Lott, G.A., 1976, Precipitable water over the United States, Volume I. Monthly means: U.S. Department of Commerce, National Oceanic and Atmospheric Administration, National Weather Service, NOAA Technical Report NWS 20, 173 p.

Miller, J.F., 1964, Two to ten-day precipitation for return periods of 2 to 100 years in the contiguous United States: U.S. Weather Bureau Technical Paper No. 49, 29 p.

Moore, P.L., and Smith, D.L., 1979, Manually digitized radar data interpretation and application: U.S. Department of Commerce, National Oceanic and Atmospheric Administration, National Weather Service, Southern Region, Scientific Service Division, NOAA Technical Memorandum NWS SR-99, 24 p.
National Oceanic and Atmospheric Administration. 1978, Storm data. August 1978: U.S. Department of Commerce, National Oceanic and Atmospheric Administration, Environmental Data and Information Service, National Climatic Center, $24 \mathrm{p}$.

Paulhus, J.L.H., 1965, Indian Ocean and Taiwan rainfalls set new records: Monthly Weather Review 93, p. 331-335.

Schofield, R.A., and Oliver, V.J., 1977, A scheme for estimating convective rainfall from satellite imagery: U.S. Department of Commerce, National Oceanic and Atmospheric Administration. National Environmental Satellite Service, Washington, D.C., NOAA/NESS Technical Memorandum 86, $47 \mathrm{p}$.

1980, Some improvements to the Schofield/Oliver technique: American Meteorological Society Second Conference on Flash Floods, Atlanta, Georgia, March 18-20, 1980, preprints, p. 115-122.

Schreiner, L.C., and Riedel, J.T., 1978, Probable maximum precipitation estimates, United States east of the 105th meridian: U.S. Department of Commerce, National Oceanic and Atmospheric Administration, National Weather Service and U.S. Army Corps of Engineers, 87 p.

Schroeder, E.E., Grozier, R.U., Hahl, D.C., and Hulme, A.E., 1974, Floods of September-October 1967 in south Texas and north-eastern Mexico: U.S. Geological Survey Water-Supply Paper 1880-B, 111 p.

Schroeder, E.E., and Massey. B.C., 1977, Techniques for estimating the magnitude and frequency of floods in Texas: U.S. Geological Survey Water-Resources Investigations 77-110, $22 \mathrm{p}$.

Shipe, A.P., and Riedel, J.T., 1976, Greatest known areal station rainfall depths of the contiguous United States: U.S Department of Commerce, National Oceanic and Atmospheric Administration, National Weather Service, NOAA Technical Memorandum NWS HYDRO 33, 250 p.

U.S. Water Resources Council, 1977, Guidelines for determining flood flow frequency: Hydrology Committee, Bulletin 17A, 26 p., 14 apps.

Yost. I.D., 1963, Floods of April-June 1957 in Texas and adjacent states: U.S. Geological Survey Water-Supply Paper 1652-B, 321 p. 